Final Report

FHWA/IN/JTRP-2002/21

\title{
AN INITIAL EVALUATION OF DESIGN-BUILD HIGHWAY PROJECTS PERFORMED BY INDIANA DEPARTMENT OF TRANSPORTATION
}

\author{
by \\ Nicholas Tymvios \\ Graduate Research Assistant \\ Bobby G. McCullouch \\ Research Scientist \\ and \\ Kumares C. Sinha \\ Olson Distinguished Professor of Civil Engineering \\ School of Civil Engineering \\ Purdue University \\ Joint Transportation Research Program \\ Project No.: C-36-73S \\ File No.: 3-4-19 \\ SPR-2497
}

The contents of this report reflect the views of the authors who are responsible for the facts and accuracy of the data presented herein. The contents do not necessarily reflect the official views or policies of the Indiana Department of Transportation and Federal Highway Administration. This report does not constitute a standard, specification, or regulation.

Purdue University

West Lafayette, Indiana

November 15, 2002 


\section{Acknowledgements}

\section{Study Advisory Committee (SAC) Members}

Paul Berebitsky, Indiana Contractors, Inc.

Timothy D. Bertram, INDOT Contracts and Construction

John A. Crone, Berns Construction Company, Inc.

Walter Land, INDOT Contracts and Construction

Dick O'Connor, RQAW

Barry Partridge, INDOT Research

Richard Smutzer, INDOT Chief Engineer

Valdis Straumins, FHWA

The contribution made by the SAC members as well as members of ACEC of Indiana and ICI and other INDOT personnel is gratefully acknowledged. This report was reviewed by the SAC and their comments have been incorporated. A detailed response from the Indiana Constructors, Inc. is also included in the appendix. 


\section{TECHNICAL Summary}

INDOT Research

Technology Transfer and Project Implementation Information

TRB Subject Code:33-1 Construction Control

Publication No.: FHWA/IN/JTRP-2002/21, SPR-2497

September 2002

Final Report

\section{An Initial Evaluation of Design-Build Highway Projects Performed by the Indiana Department of Transportation}

\section{Introduction}

The Indiana Department of Transportation (INDOT) has used the Design-Build contract delivery method on a few projects and received mixed responses from those involved in the process. Because of these differing reactions, INDOT felt that an evaluation of its Design-
Build program was appropriate to determine its future use in Indiana. This project therefore conducted this analysis and evaluation, which included an examination of the Design-Build programs and practices of other DOTs.

\section{Findings}

The Design-Build process has been successful with other organizations, both private and public. Its proven benefits are: 1) a shorter time to bring the project on-line by reducing design time; 2) improved cooperation and sharing between the designer and the contractor, which in turn creates a more effective effort; 3) less uncertainty in final construction costs; and 4) reduced supervisory needs from the DOT.

\section{Implementation}

The continued use of Design-Build by INDOT can be supported. However, to improve its acceptance and use, the following recommendations are made.

1. The Design-Build program should include smaller projects because the larger projects have excluded many Indiana contractors due to the financial risks that are involved with large projects. Even though several states, like Arizona, have only experimented with large-scale projects and have been quite satisfied with their performance, smaller projects will be more appealing to the majority of Indiana contractors. States like Ohio and Florida have used Design-Build for projects that range from one million to several hundred million dollars. Experiences from these states indicate that Design-Build can be a successful approach regardless of the job size.

2. Because Design-Build is a fast paced method of construction, it is desirable to have a large part of the design ready before the contractor starts any site work. To achieve this, the Design-Build projects should be awarded during late fall so that during the dead construction period in winter, the consultant can prepare a substantial amount of the design, thus eliminating possible errors that might arise due to rushing to completion and lack of proper plan review. This will also help subcontractors involved in the early activities. Also, only projects that are free of utility problems should be considered for Design-Build. 
3. The level of design required of INDOT and its consultants should be determined before letting. Information from other states indicates the following. In signals and lighting, most of the DOTs perform a large portion of the design, which sometimes can reach $80 \%$ to $90 \%$. In roads and bridges, most of the agencies performed $15 \%$ to $25 \%$ of the design.

4. Requirements for the submission of the technical proposal need to be evaluated in order to minimize costs and maximize the participation of consulting firms. The costs associated with the preparation of technical proposals are often so large that many firms shy away from participating. A concern mentioned by the consultants and the contractors alike is that the stipend given to the unsuccessful bidders is too low and covered only approximately $20 \%$ of their costs. INDOT should consider either increasing the stipend amount or reducing the submittal requirements. For instance, if innovation is not used in selecting a contractor, then this requirement should be removed. If cost alone is the only selection criterion, then all other submittal requirements need to be evaluated for elimination. If proposal requirements were closer to those expended for a traditional Design-Bid-Build contract, more firms would be interested and would participate in the program.

5. A number of participating firms indicated that there were changes made in the scope during the technical proposal development, hindering some firms from completing their necessary documents in time. It has been suggested that time extensions be granted with any change in scope. Also, both contractors and consultants recommended improving the scope of work they receive.

6. Due to the accelerated pace of DesignBuild, INDOT needs to evaluate the personnel needed to adequately supervise. Some projects have used a 24-hour schedule, which has created problems for INDOT supervisory personnel and quality concerns.

7. In order to improve the understanding of the Design-Build process among contractors and consultants in Indiana, information sessions should be conducted. Similar sessions have been used in other states in order to eliminate concerns and worries that prospective participants might have and to explain the program procedures. At the same time, INDOT should have a continual training process to inform its personnel of their responsibilities. INDOT personnel from the districts, as well as from the Central Office, should meet to share concerns and experiences from DesignBuild projects and gain knowledge and insight from each project. It would be beneficial to develop a correspondence/ communication flowchart. This can effectively eliminate misunderstandings that might occur due to miscommunications between project participants. Also, it would be beneficial to develop project management guidelines.

\section{Contacts}

For more information:

Dr. Bob McCullouch

Principal Investigator

School of Civil Engineering

Purdue University

West Lafayette IN 47907

Phone: (765) 494-0643

Fax: (765) 496-1364

Prof. Kumares Sinha

Principal Investigator

School of Civil Engineering

Purdue University

West Lafayette IN 47907

Phone: (765) 494-2211

Fax: (765) 496-1105
Indiana Department of Transportation

Division of Research

1205 Montgomery Street

P.O. Box 2279

West Lafayette, IN 47906

Phone: (765) 463-1521

Fax: (765) 497-1665

\section{Purdue University}

Joint Transportation Research Program

School of Civil Engineering

West Lafayette, IN 47907-1284

Phone: (765) 494-9310

Fax: (765) 496-1105 
TECHNICAL REPORT STANDARD TITLE PAGE

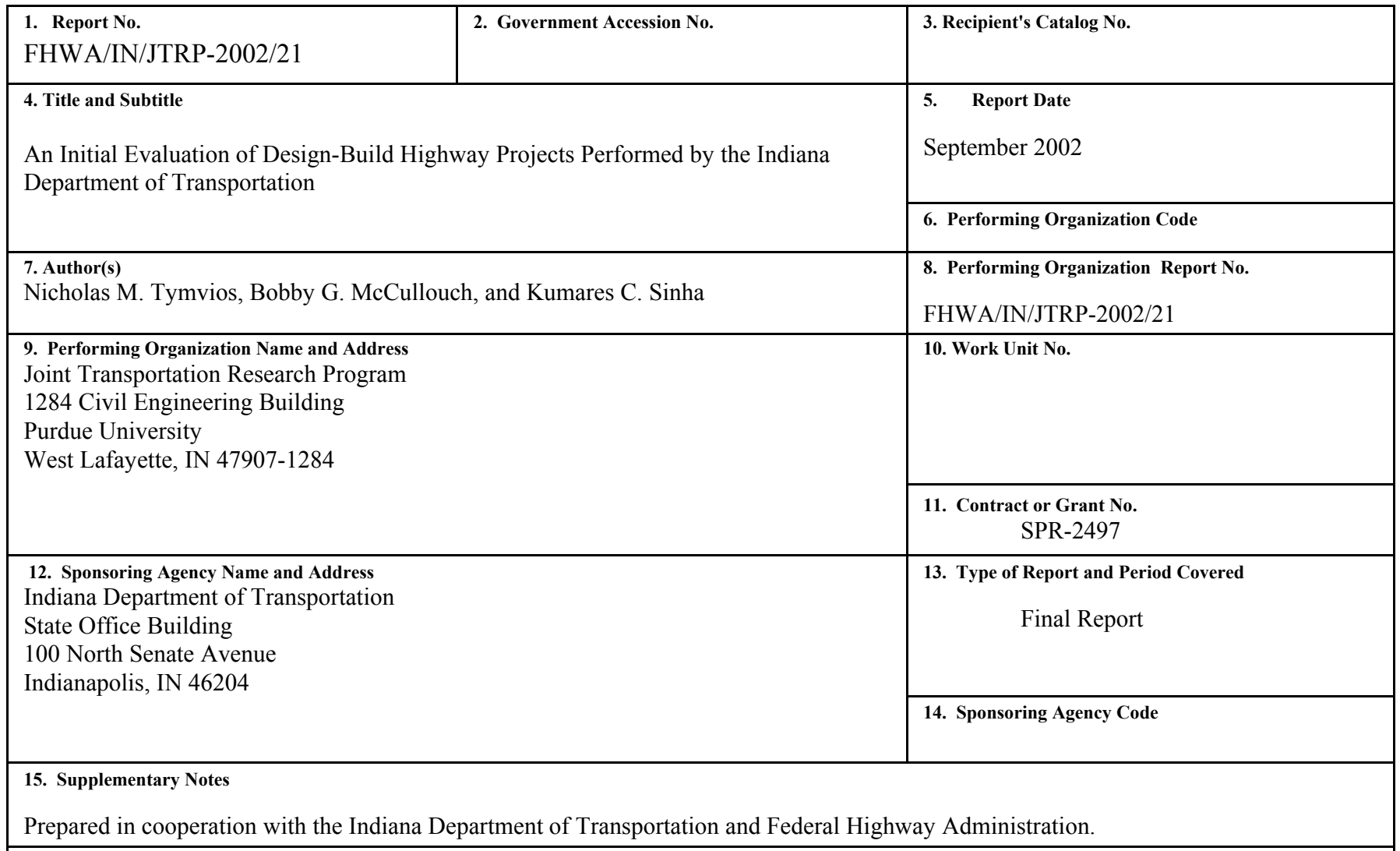

\section{Abstract}

Design-Build has been an effective contracting method in the private and public arenas. Departments of Transportation have used this contracting method on various projects for a variety of reasons. The Indiana Department of Transportation (INDOT) has used this contract delivery method on a few projects with mixed responses from those involved in the process. INDOT therefore felt that an evaluation of the Design-Build program was appropriate to determine its future use in Indiana. This report gives a historical perspective of Design-Build and how the program has been received and perceived by INDOT; describes the project's survey and the data collected from the designer and contractor perspectives; relates the experiences of other Departments of Transportation with Design-Build; provides a somewhat limited comparison with the Design-Bid-Build approach; and makes recommendations for INDOT's future Design-Build practices.

\section{Key Words}

change orders, constructability, consultant, contractor, design-build, design-bid-build, designer, stipend, subcontractors, survey

19. Security Classif. (of this report)
Unclassified

20. Security Classif. (of this page)
Unclassified
Unclassified
18. Distribution Statement

No restrictions. This document is available to the public through the National Technical Information Service, Springfield, VA 22161 


\section{Table of Contents}

Acknowledgements

Page No.

Table of Contents

List of Figures

List of Tables

iv

1. Introduction

vi

1.1 History

1.2 Design-Build in the United States

1.3 Design-Build Practices in Other States

1.4 Design-Build in Indiana

2. Study Objective

3. Initial Survey 9

$\begin{array}{ll}3.1 \text { INDOT Personnel Survey } & 10\end{array}$

3.2 INDOT Consultants Survey 16

3.3 Design-Build Teams Survey 19

3.4 Summary of Responses 23

4. Survey of Indiana Constructors, Inc. (ICI) and American Council of 36 Engineering Companies (ACEC) of Indiana Members

4.1 Responses of the ICI Members 36

4.2 Responses of the ACEC of Indiana Members 49

4.3 Summary of Responses $\quad 60$

5. Follow-up Interviews

5.1 INDOT Personnel 72

5.2 Contractor and Subcontractor Members of ICI 74

5.3 Consultant Members of ACEC of Indiana 77

6. Summary

7. Case Studies $\quad 80$

8. Conclusions $\quad 84$

References $\quad 89$

Appendix A. Design-Build Practices by Different States Under SEP 14

Appendix B-1. Design-Build Questionnaire for INDOT Personnel 93

Appendix B-2. Design-Build Questionnaire for INDOT Consultants 97

Appendix B-3. Design-Build Questionnaire for Design-Build Teams 100 
Appendix C-1. Design-Build Questionnaire for Members of ICI

Appendix C-2. Design-Build Questionnaire for Members of ACEC 108

Appendix D. Comments from Indiana Constructors, Inc. 113 


\section{$\underline{\text { List of Figures }}$}

Figure No.

Figure Title

Page No.

$1 \quad$ State DOTs Using Design-Build

2 ICI members considering participation in INDOT Design-

Build projects

3 ICI member participation in INDOT Design-Build projects

4 ICI members considering participation in INDOT Design-

Build projects in the future

5 ICI member opinions: Does Design-Build reduce duration of construction?

6 ICI member opinions: Does Design-Build introduce innovation and improve constructability?

7 ICI member opinions: Does Design-Build reduce construction costs?

8 ICI member opinions: Is there a single point responsibility with Design-Build?

9 ICI member opinions: Is there continuity between construction and design in Design-Build?

10 ICI member opinions: Are there fewer misunderstandings between parties in Design-Build?

11 ICI member opinions: Does Design-Build limit competition?

12 ICI member opinions: Does Design-Build increase construction costs?

13 ICI member opinions: Do Design-Build projects take longer to construct?

14 ICI member opinions: Does Design-Build discourage designers to participate due to higher risks involved?

15 ICI member opinions: Are design decisions in Design-Build not always influenced by the designer?

16 ICI member opinions: Could the Design-Build designer be 
Figure No.

17

18 ACEC of Indiana member opinions: Does Design-Build reduce duration of construction?

19 ACEC of Indiana member opinions: Does Design-Build introduce innovation and improve constructability?

20 ACEC of Indiana member opinions: Does Design-Build reduce construction costs?

21 ACEC of Indiana member opinions: Does the Design-Build team have full responsibility for the outcome of the project?

22 ACEC of Indiana member opinions: Is there continuity between construction and design in Design-Build?

23 ACEC of Indiana member opinions: Are there fewer misunderstandings between parties in Design-Build?

24 ACEC of Indiana member opinions: Does the owner lose control of the project's design in Design-Build?

25 ACEC of Indiana member opinions: Do Design-Build teams build first and design later?

26 ACEC of Indiana member opinions: Does the owner have less control of the quality and the materials used in Design-Build?

27 ACEC of Indiana member opinions: Are Design-Build projects more labor-intensive for the owner?

28 ACEC of Indiana member opinions: Could the Design-Build designer be chosen on the basis of price rather than qualifications?

29 ACEC of Indiana member opinions: Does Design-Build limit competition?

30 ACEC of Indiana member opinions: Does Design-Build discourage designers to participate due to higher risks involved?

$31 \quad$ Project Locations
Page No.

48

50

51

51

52

53

53

54

55

55

56

57

57 


\section{$\underline{\text { List of Tables }}$}

Table No.

Table Title

Page No.

1 Summary of Responses from INDOT, INDOT Consultants and

Design-Build Teams Surveys

2 Summary of Responses from ICI and ACEC of Indiana Survey

61

3 Summary of Data Collected from Design-Build and Design-

82 Bid-Build INDOT Projects 


\section{Introduction}

\subsection{History}

Design-Build, as a method of procurement, is not a new concept. There have been traces of its use since ancient times. It was seen as early as 1800 BC in ancient Mesopotamia, when the Code of Hammurabi assigned master builders absolute responsibility for design and construction [1]. The term "master builder" refers to the person or entity responsible for the design and construction of a particular project, and consequently, that person had to master both aspects required for the completion of the project. Later on, in Greece, master builders designed and built temples, public buildings, and other civil works [1]. Evidence of such structures that are still standing are the Parthenon, built by the renowned master builder Callicrates in $432 \mathrm{BC}$, and the Theater of Dionysus, built by Lycurgus between 338 and 326 BC [2].

During the Renaissance, architecture and construction evolved into two distinct professions and the requirement of a master builder became obsolete. This was due to the fact that project complexity increased and the need for specialization in construction, as well as design, was required. With the development of statutory law in the 1800's, architects were only liable for negligence, while the contractors were faced with stricter guidelines. This caused the "traditional" Design-Bid-Build method to emerge as the primary procurement method [3].

In the 1970's and 1980's, changes in the economy encouraged owner organizations to reevaluate the Design-Bid-Build method. As a result, alternative methods were developed, such as Design-Build, Turnkey, and construction management. Design-Build has experienced an astonishing growth in recent years in terms of previous volume and percentage of total construction [1]. 


\subsection{Design-Build in the United States}

Even though Design-Build has been used in the United States since the 1970's, the public sector has been slow in utilizing this method. The Federal Highway Administration (FHWA) in Special Experimental Project 14 (SEP 14) encourages state Departments of Transportation to use "Innovative Contracting Practices" such as Design-Build. Of the 50 state DOTs, only 20 and the District of Columbia have so far used Design-Build as a method of procurement under the guidelines of SEP 14 [4].

There is significant variation in project types and the extent to which Design-Build is used the different states. Some states like Ohio have utilized Design-Build in a significant number of projects, while others like Michigan experimented only with one or two projects. Some states also combine Design-Build with warranty and project maintenance in an effort to achieve good project quality [4]. Appendix A contains a table showing the different uses of Design-Build under SEP 14. A graphical representation of the states that have used the Design-Build method as of 2001 is shown in Figure 1. A brief description of experiences of various states with Design-Build is included in Section 1.3.

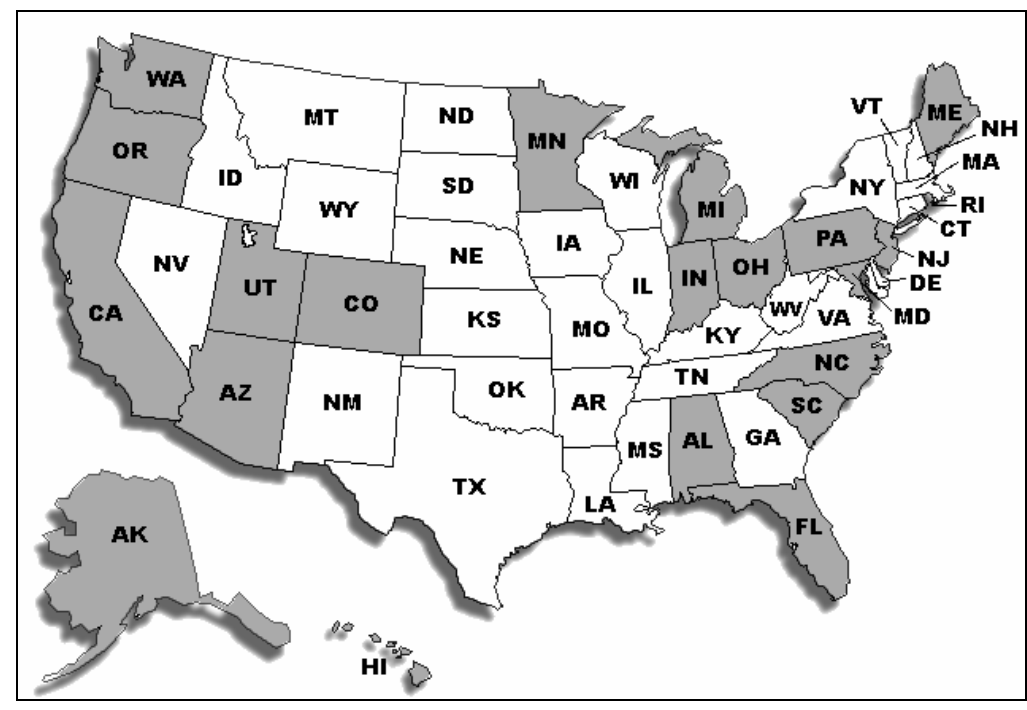

Figure 1 - State DOTs Using Design-Build (shown shaded) 


\subsection{Design-Build Practices in Other States}

Design-Build practices vary across the country. Following is a summary of the applications of other states.

Alabama Department of Transportation: The Alabama DOT let a DesignBuild contract on a ferryboat. A resurfacing project that was planned to take place was not completed. The Alabama DOT contact did not have an explanation for this course of action [4] [5].

Alaska Department of Transportation: The Alaska DOT used the DesignBuild method of procurement for an Ocean Class Vessel for the Alaska Marine Highway System [4].

Arizona Department of Transportation: ADOT has constructed three highway projects and is in the process of completing a fourth. Their costs range from $\$ 45$ million to $\$ 185$ million. These projects include improvements on the existing interstates and addition of lanes. One of the projects is on mountainous terrain, which increased the complexity of the project. ADOT is not using a warranty on the highway resurfacing projects. They have not experienced any problems regarding signals and lighting since a very detailed scope of the work is given to the participating firms and they also do $80 \%$ of the signal and lighting design in-house. In situations where ADOT had to perform bridge replacement, no problems were experienced. The ADOT contact commented that there was innovation in the four projects that were performed. They were included in the technical proposals that were submitted by the Design-Build teams, but no prices were included at that point [4] [6] [7].

California Department of Transportation: CALTRANS, by law, is not permitted to participate in any Design-Build projects. Other entities in California, such as toll agencies, have completed a number of Design-Build highway projects, which were not federally funded. These corridors provided $96 \mathrm{~km}$ of new freeways at a total cost of $\$ 2.5$ billion [4] [8].

Colorado Department of Transportation: CDOT has completed two pilot projects using Design-Build, both of which were reconstruction projects of 
existing highways. No warranties were required for these projects, and CDOT contact did not mention any problems or concerns regarding the construction of the projects. The first project was a reconstruction of a 12-mile stretch on I-70, while the second was a 17-mile concrete overlay of four lanes on I-25 and included some bridge and safety improvements [4] [9] [10].

District of Columbia Department of Public Works: DCDPW initiated a Design-Build-Warrant project for the reconstruction and improvement of an enhanced vehicle and emissions inspection testing station in southwest DC. The award was made to the bidder with the highest cumulative ratings based on price and quality considerations, and the project included a two-year warranty [4].

Florida Department of Transportation: FDOT has had extensive experience with Design-Build. The Florida legislature passed a bill in 1987 authorizing the FDOT to undertake transportation-related contracting based on Design-Build. FDOT started with an 11-project Design-Build pilot program with a total cost of $\$ 30.5$ million. These projects included six resurfacing projects, one major bridge replacement, one bridge widening, one multi-lane project, and two parking garages. A study conducted by the University of Florida estimated that there was an $18 \%$ decrease in construction time, a $54 \%$ decrease in design time, a $36 \%$ decrease in design and construction time, and a 5\% increase in cost for these 11 projects. FDOT has enforced a $\$ 120$ million cap per year for Design-Build projects and in a 10-year period from 1996 until 2005, 49 Design-Build projects with an estimated total cost of $\$ 699$ million have been completed or are nearing completion. Warranties are not being utilized in FDOT's resurfacing projects, but they have used a warranty in its major bridge construction projects. No particular concerns were mentioned by the FDOT contact [4] [11].

Hawaii Department of Transportation: HDOT has one project planned, a 5.2-mile highway from West Maui to Kahului Airport [4].

Maine Department of Transportation: In August 2000 MDOT completed its first Design-Build project, which was a $\$ 46.6$ million bridge project (Sagadoc Bridge) over the Kennebec River; between the City of Bath and the town of Woolwich. The MDOT contact did not indicate that any problems were 
experienced during the construction of the project, and there were also no claims on this project. MDOT has no other Design-Build projects planned at this time [4] [13] [14].

Maryland State Highway Administration: Maryland SHA has completed four Design-Build projects, ranging from \$2 million to \$20 million. Eight more projects are currently under construction or are planned in the near future. Warranties are not being utilized in their highway resurfacing projects, and they are performing all of the design for signals and lighting work and bridge replacement for Design-Build projects [4] [12].

Michigan Department of Transportation: MDOT is using the Design-Build concept for an Intelligent Transportation System project for deployment in the Detroit metropolitan area. The contractor will design, procure, and construct a traffic management system on I-75 and I-696 that will include mainline detectors, closed circuit TV cameras, variable message signs, highway advisory radio transmitters, and ramp metering. The contract also includes a two-year warranty provision for all procured and developed items.

MDOT has also received approval to use Design-Build to construct a new interchange at I-94 and Vining Road in the City of Romulus and is using a Design-Build program to accelerate their delivery of projects for the annual statewide bridge rehabilitation program. In 1995 the annual funding level for the bridge program increased from about $\$ 60$ million to $\$ 110$ million, and MDOT hopes to rehabilitate 15 structures per year under this program. The Design-Build contracts are awarded based on the low bid concept or on the basis of cost-plustime bidding. The Beaver Island Transportation Authority was allocated \$2.4 million in Ferry Boat Discretionary funds to replace the 40-year-old ferry that operates between Beaver Island in Lake Michigan and the mainland, for which they are using the Design-Build-Warrant method. [4] [15].

Minnesota Department of Transportation: MnDOT has two highway projects planned, one on Truck Highway 14 and the other on Truck Highway 100. The first project was let in 2001 and is expected to be completed by the end of 2002. If traditional methods were used, the project would have been let in 
February of 2003 and completed by the end of that year. Work on the second project began in the fall of 2001 and is expected to be completed by 2003, which if the traditional method of procurement was used, the project would have be let in the fall of 2002 and completed by the end of 2003. The timelines of the projects are conservative and the contractors are expected to finish work ahead of schedule. Both projects are in the $\$ 20$ million range [4] [25].

In order to develop the Design - Bid program, MnDOT organized and conducted a workshop in 2001 for the contractor and consultant communities. The workshop gave everyone involved the program the opportunity to raise their concerns, provided education to the participants and sought input, ideas and concerns about MnDOT using Design-Build in the future. At the end of the workshop, a model for selecting projects was developed that identifies the Design-Build method to be used, as well as the procurement option [25].

New Jersey Department of Transportation: NJDOT has used Design-Build for the construction of approximately 20 bridges with an estimated cost of $\$ 750$ million. NJDOT has completed many successful projects with numerous innovative suggestions by the participating Design-Build teams. NJDOT indicated that time was saved in the projects using Design-Build, however, they will not be continuing using it because of two unsuccessful projects, one of which was a drawbridge where the contractor did not follow NJDOT specifications and the other was a tunnel project where there were several issues involved [4] [16].

North Carolina Department of Transportation: NCDOT has constructed several Design-Build projects, ranging from small railroad bridge replacements to major interstate widening, with costs ranging from $\$ 6$ million to $\$ 180$ million. NCDOT did not use warranties in its highway pavement resurfacing work and did most of the signal and lighting design themselves. NCDOT developed its DesignBuild program in collaboration with the North Carolina contracting community[4] [17].

Ohio Department of Transportation: In 2000 ODOT began constructing a large number of Design-Build projects, ranging from $\$ 0.5$ million bridge replacement projects to $\$ 50$ million lane addition highway improvement projects. 
ODOT's Design-Build budget in 2000 was $\$ 140$ million, while its estimated budget for 2001 was $\$ 106$ million. ODOT has several more projects planned for 2002 and 2003. It has not used warranties in its projects and the contact at ODOT did not express any problems with the signing and lighting or the bridge replacement projects. The ODOT contact indicated that they experienced a few problems in the interpretation of the scope by the Design-Build teams, but these were resolved as more projects were constructed. They also found that many designers were unwilling to participate in small projects [4] [18] [19].

Oregon Department of Transportation: ODOT has thus far constructed two projects and another is underway, ranging from $\$ 2.5$ million to $\$ 7.5$ million, that include highway improvement work and bridge replacement. The Oregon DOT is not using a warranty in its projects. No major problems were encountered during construction of the projects and any difficulties that occurred were no different than traditional Design-Bid-Build projects. The department saw "outstanding" solutions in their signals and lighting work on the project [4] [20].

Pennsylvania Department of Transportation: PennDOT is developing a Design-Build-Maintain contract that will provide for wetland banking on U.S. Route 220 in western Pennsylvania [4].

South Carolina Department of Transportation: South Carolina DOT (SCDOT) has two projects underway. One is the widening of SC 170 including two major bridges, while the second project is the Maybank Bridge Replacement and Road Widening Project on SC 700. For the first project, there will be a 10year warranty for the bridge structures, exclusive of joints, bearings and drainage systems, which will have a five-year warranty. There will also be a five-year warranty for the structural integrity of the roadway. Since both of the projects are just recently underway, no major concerns have been noticed. Some erosion was noticed on the highways, but it was not directly related to the Design-Build method [4] [21].

Utah Department of Transportation: UDOT recently completed the construction of the $\$ 1.6$ billion one-contract project in time for the 2002 Olympics in Salt Lake City. Specifically I-15, which is the major north-south arterial in the 
Salt Lake City area, was reconstructed and involved the replacement of the sixlane highway with eight lanes, the addition of high occupancy vehicle and auxiliary vehicle lanes in each direction, reconstruction of 142 bridges, and installation of the latest automated traffic-management system. The Design-Build approach is estimated to have saved UDOT about three years. The complete project from conception to completion took 4.5 years [4] [22] [25].

Washington Department of Transportation: WDOT is currently involved in a \$20 million grade separation project, which is their pilot Design-Build project. With completion expected by fall of 2002, WDOT estimates that DesignBuild is about $20 \%$ to $30 \%$ more expensive in comparison to traditional DesignBid-Build but a great deal of time has been saved from conception to completion [4] [23].

\subsection{Design-Build in Indiana}

The private sector in Indiana has used the Design-Build method since its reinvention in the 1970's. However, state and federal legislation inhibited its use in the public sector. SEP 14, which deals with Innovative Contracting Practices, encouraged the use of Design-Build as a method of procurement for several highway projects [24] and the Indiana Department of Transportation (INDOT) has begun to do so. As of December 2001, the following projects were completed or are under construction:

- Project No. 1

Contract R-23500, A+B +C Contact, Crawfordsville District, Tippecanoe and White Counties, I-65, $3.94 \mathrm{~km}$ to Hollingsworth Ditch, 17.56 miles.

- Project No. 2

Contract R-24330 A Contract, LaPorte District, Lake County, I-65, 0.2 miles north of US 30 to 0.3 miles north of $61^{\text {st }}$ street, 3.3 miles. 
- $\quad$ Project No. 3

Contract R-25035, A Contract, LaPorte District, Lake County, I-65, 0.3 mile north of $61^{\text {st }}$ street to I- $80,3.2$ miles.

- Project No. 4

Contract R-24327, A+B+C, Greenfield District, Marion County, I-65, 0.15 west of Kessler Boulevard to 0.5 mile north of I-465, 5.25 miles.

- Project No. 5

Contract R-25386, A Contract, Greenfield District, Marion County, I70 \& I-465 interchange, 3.3 miles.

The following projects are currently in the design phase:

- I-65, US 30, Interchange

- I-80, I-90, Bridges over the Borman Expressway

The following project is in the developmental phase:

- I-80, Lake County

\section{Study Objective}

The objective of the study is to assess the impact of INDOT's Design-Build program, and the factors considered in this assessment include personnel needs, risks, costs, timesavings, and scheduling. In addition, the study attempts to generate information that can be used by INDOT in making decisions on the best use of the Design-Build contracting process for timely execution of highway projects.

\section{Initial Survey}

Questionnaires were designed in consultation with the members of the Study Advisory Committee and sent to INDOT personnel and the Design-Build teams that participated in the first five projects listed above. All three questionnaires are shown in Appendix B. 
The first questionnaire was directed to fifteen INDOT personnel. Six replies were received for a $40 \%$ response. The second questionnaire was sent to the three consultants hired by INDOT to perform the pre-bid design. One response was received for a reply of $33.3 \%$. The third questionnaire was sent to the eight DesignBuild teams that participated in the construction of the projects. Five replies were received for a response rate of $62.5 \%$. Survey responses are discussed in the following sections.

\subsection{INDOT Personnel Survey}

The survey of INDOT personnel attempted to gather information about all aspects of the Design-Build process, i.e., planning, pre-bid process, construction phase, and post-construction phase. The responses are presented below.

\subsubsection{Initial Work}

Question 1: Which projects did you work on?

Participants from all five projects responded to the survey.

Question 2: How long did it take INDOT to complete the initial design work, and what percentage of design INDOT and/or its consultant perform?

The personnel that responded to this question did not have the knowledge to reply.

Question 3: Was the scope of the project well defined?

Of the responses, four mentioned that the scope was well defined from the beginning of the project, while one felt that the scope was not well defined. One comment made was that INDOT should choose the Design-Build team and it should not be selected from bidding results. With this method, INDOT should be performing the minimum design required up front, while the Design-Build team should be completing the design work and then having it approved by INDOT. 
Question 4: Were there any changes made in the scope of the project after the Design-Build team won the bid?

All the responses indicated there were a few changes in the scope of the projects.

Question 5: If 'Yes' in Question 4, please explain reasons for change.

Most of the changes made were to improve traffic flow and to ease construction.

Question 6: Did these changes cause friction between INDOT and DesignBuild teams?

The responses indicated that there was no friction and the changes were mutually agreed upon.

\subsubsection{Pre-bid}

Question 1: What percentage of design do you consider necessary to be performed by INDOT and/or its consultants?

Four of the respondents on this question indicated that INDOT should perform very little design. They indicated that INDOT should perform $5 \%$ to $10 \%$ of the design work, preliminary engineering, and a well-defined scope. One of the respondents indicated that $100 \%$ of the design should be performed by the Design-Build team. One respondent indicated about 40\%, while another response indicated $100 \%$. There were a total of six responses.

Question 2: In the projects that you worked on, was the design performed by INDOT and/or its consultants adequate for the bidding Design-Build teams to complete their bid?

All of the respondents on this question indicated the design work was adequate for bidding.

Question 3: Was there enough time for the bidding firms to complete their bid?

Of the five responses to this question, three indicated that the Design-Build teams had enough time to complete their bid, while two indicated that there 
was not enough time. One respondent indicated that the bidding teams should have a six to nine month period to complete their bid.

Question 4: Do you believe that there is a higher requirement for detailed description of the design preferences in Design-Build projects compared to Design - Bid-Build projects?

Four respondents replied. Three agreed that there is a higher need for a detailed description of the design preferences. This was based on the opinion that Design-Build gets by with the minimum design necessary and many of the details are lacking. The respondents would prefer to have the certainty that some features are installed and quality is achieved. One respondent indicated that only the scope should be given to the Design-Build teams with no extensive design.

\subsubsection{Construction Phase}

Question 1: Were you satisfied by the design performed by the Design-Build teams?

On this question four of the responses were negative while two were positive. The basis for the negative responses was that the teams were using too many short cuts and there were errors in the plans. The responses that were positive claimed that the response time and the preparation of the plans was adequate.

Question 2: Did the design performed by the Design-Build teams meet INDOT specifications?

Five of the six respondents indicated that the design performed by the DesignBuild firms satisfied all INDOT standards.

Question 3: Was there any innovation in design?

The responses were uniform in the fact that there were few innovations made and those were in constructibility issues.

Question 4: During construction did you perform any inspection and quality control on the projects?

Three of the responses indicated that they performed inspection on the projects. No problems were mentioned. 
Question 5: Were there any errors found during construction?

Three of the four respondents indicated that there were minor errors, and they could readily be corrected. The reasons for these errors were limited time and inexperience of the contractor's teams. One of the respondents indicated that there were many errors and the reason for this was the poor construction layout done by the contractor.

Question 6: If yes in Question 5, what were the causes of these errors?

The errors that were made during construction were due to oversight and inexperience. The tight construction schedule caused some errors because the construction crews were in a constant rush.

Question 7: Were there delays caused by right-of-way issues?

There were no delays due to right-of-way issues.

Question 8: Was there any miscommunication between the Design-Build team and INDOT?

Four of the respondents replied. One indicated that there was little or minimum miscommunication. While three mentioned that it was considerable.

Question 9: What could have been done to avoid these miscommunications?

Two indicated that some changes needed to be implemented in the DesignBuild method in order to reduce any miscommunication issues that might arise. Nothing was specifically mentioned.

Question 10: Do you believe you had enough personnel at the site for Quality Assurance?

The responses indicated that the INDOT, either with its own personnel or through consultants, had enough people on the job, most of the time, to perform quality assurance. Because of the tight construction schedule, some of the INDOT personnel did not have adequate time to perform their job.

Question 11: Do you think that it is better if the control of the quality checks fall on the Design-Build teams?

Five respondents replied and indicated that letting the Design-Build team perform all the quality checks is not a good idea, but if the Design-Build 
projects have complete warranty, then the Design-Build teams will have a bigger incentive to perform quality work.

Question 12: Do you think INDOT has fewer responsibilities for inspection, testing and quality control?

The replies to this question were in agreement that INDOT had less paper work to complete, but INDOT personnel treated the Design-Build jobs just like any other.

Question 13: Do you believe the Design-Build team had tendencies to assume that the plans were only a guideline and field changes could be made without the review of the design by their design personnel?

Three of the respondents said that the Design-Build teams had no tendency to assume the above, but the other three indicated that if the contractor did not like something in the design he would ask the designer to make the necessary changes.

\subsubsection{Post-Construction Phase}

Question 1: Are you satisfied with the performance of Design-Build projects in regards to the overall quality of the project?

In regards to the quality of the project the INDOT response was split. Three were satisfied while the other three were not. The negative responses claimed that the quality in most areas was lacking.

Question 2: Were the projects delivered in adequate time or were there delays?

Five of the responses were affirmative, since the schedule was aggressive and delivery of work completion was ahead of completion date. One response was negative suggesting that the project was not completed on time.

Question 3: Were these delays caused by construction or by the pre-bid design process?

One of the two respondents mentioned that some delays were caused by faults in the construction equipment and were not in any respect caused by the Design-Build project. The other respondent did not mention specifics, but 
indicated that delays were caused by both the construction and the pre-bid design process.

Question 4: In comparison to projects performed by the Design-Bid-Build method, were there more or less delays in the Design-Build projects?

Two of the respondents replied. One indicated that there were fewer delays because the contractor wanted to finish early, while the second said that there were more delays in the Design-Build project.

Question 5: Do you think the Design-Build method costs less than the DesignBid-Build approach?

Two of the respondents replied and indicated that the Design-Build process costs more than the Design-Bid-Build.

Question 6: Based on your experiences, is Design-Build a good alternative to the Design-Bid-Build method?

Two of the three responses were negative towards Design-Build and claimed that there were too many corners cut in design and too many mistakes made leading to marginally acceptable work. The affirmative response claimed that the Design-Build method works well in getting the job done faster, thus improving public opinion toward highway projects, which tend to be long lasting.

Question 7: What are the advantages of Design-Build based on the projects you were involved?

One respondent indicated that there are no advantages while the other three indicated that there is a lot of time saved.

Question 8: What are the disadvantages of Design-Build based on the projects you were involved?

There were five responses to this question. Some of the disadvantages claimed were poor quality and design, confusion, more people are required as team leaders, and Design-Build requires total commitment every day. There is also more opportunity for errors due to the reduced review time and time pressures. 


\subsection{INDOT Consultants Survey}

Only one person out of three consultants replied to the questionnaire, and for that reason the responses below cannot be considered representative.

\subsubsection{Initial Work}

Question 1: Which Design-Build projects did you work on?

Here the consultant stated the projects that he participated on.

Question 2: Was the scope of the project clearly explained from the beginning?

The consultant indicated that the scope was clearly defined.

Question 3: Were there necessary changes that needed to be made in the scope of the project?

There were some changes that needed to be made to the scope but they did not cause any major delay to the Design-Build team.

Question 4: If changes were made in the scope, did they cause any delays in the design process and your interaction with the Design-Build team?

The changes made did not affect the Design-Build teams' ability to complete the bid.

\subsubsection{Pre-bid}

Question 1: Were you involved in any pre-bid design work for Design-Build projects as an INDOT consultant?

The consultant responded accordingly.

Question 2: In the pre-bid design work you were involved, was the design performed by you adequate for the Design-Build teams to complete their bid? The consultant replied affirmatively.

Question 3: Was there enough time for the bidding firms to complete their bid?

The consultant replied that there was not enough time for the Design-Build teams to complete the bid. 
Question 4: Do you believe that there is a higher requirement for detailed description of the design compared to Design-Bid-Build projects?

The INDOT consultant believes there is a higher requirement for detailed description of the design because the Design-Build teams want to gloss over criteria that they personally do not like

Question 5: What percentage of design do you consider necessary to be performed by INDOT - Consultant?

The response indicated that the level of design depends on the size and complexity of the job.

\subsubsection{Construction Phase}

Question 1: Were you satisfied by the design performed by the Design-Build team?

The response indicated that the time available for design work increased the quality of the design.

Question 2: Was there any problem for the design to meet INDOT specifications?

The consultant did not see any major problems.

Question 3: Was there innovation in design?

The response indicated that there was some innovation during the construction of the project and these innovations helped in the constructibility of the project.

Question 4: During construction did you perform any inspection and quality control on the projects?

The consultant performed plan review and Witness and Hold Point work.

Question 5: Were there any misunderstandings between INDOT consultants and Design-Build teams?

The consultant said that there was some misunderstanding between the consultant and the Design - build team caused by a misinterpretation of the plans, the scope and the specifications. 
Question 6: Were these misunderstandings caused by pre-bid design problems?

Some of the problems were caused by the pre-bid design. A better scope would have circumvented that.

Question 7: Were there delays caused by right-of-way issues?

There were no right of way issues.

Question 8: Was there any problem with communication between the DesignBuild team and INDOT?

There was some miscommunication in regards to the interpretation of the plans.

Question 9: What could have been done to avoid these miscommunications?

Produce a better scope of work

\subsubsection{Post Construction Phase}

Question 1: Are you satisfied with the performance of the Design-Build projects in regards to the overall quality of the project?

The consultant was satisfied with the performance, but no more or less than traditional Design-Bid-Build projects. Material quality issues that surfaced were not caused by the Design-Build method.

Question 2: Were there delays caused by construction or by the pre-bid design process?

The consultant did not give any definite response.

Question 3: Based on your experiences is Design-Build a good alternative to the Design-Bid-Build method?

The consultant commented that Design-Build is a good alternative to DesignBid-Build, and it is best suited for road rehabilitation projects that need to be done quickly and do not need additional right of way. Design-Build can also be used for bridge replacement, culvert replacement and slope stabilization projects. 
Question 4: What are the advantages of Design-Build based on the projects you were involved?

One advantage was the time that was saved from project inception to project completion and delivery to the public.

Question 5: What are the disadvantages of Design-Build based on the projects you were involved?

One disadvantage is the reduced time frame for generating the initial design.

\subsection{Design-Build Teams Survey}

This survey was similar to the other two, but it sought responses from the Design-Build teams (the designer and the contractor). Five responses, out of a possible eight, were received and they are discussed below.

\subsubsection{Initial Work}

Question 1: Which projects did you work on?

The responding members of the Design-Build teams gave the necessary information to this question. Participants from the first five Design-Build projects replied.

Question 2: What was the overall cost of the projects?

The participants gave the necessary information to this question.

\subsubsection{Pre-bid}

Question 1: Was the level of design performed by INDOT and their consultants sufficient for you to complete your bid?

All the members of the Design-Build teams responded affirmatively to this question.

Question 2: What percentage of design of a typical Design-Build project do you consider necessary to be performed by INDOT and their consultants? The level of design that should be performed by INDOT, as indicated by the Design-Build teams, ranged from $30 \%$ to $40 \%$. 
Question 3: Was there enough time for you to adequately complete the bid? The responses were affirmative, but commented that there were changes in the scope during the bidding process that hindered their ability to complete the proposals in an orderly, calculated manner.

\subsubsection{Construction Phase}

Question 1: Was there any problem to complete the design, according to INDOT's specifications?

All the responses were affirmative, because they were always pressed for time.

Question 2: Did construction meet the design requirements?

All of the answers were affirmative.

Question 3: Was there any innovative design or construction method employed in the Design-Build project you worked on?

The Design-Build teams said there was innovation introduced. There was some innovation in regard to constructibility issues according to some responses, while other responses indicated that all the innovation that was introduced by them was rejected by INDOT.

Question 4: Was there sufficient time for you to complete design?

The Design-Build teams unanimously said that they did complete the design work on time but the schedule was very tight.

Question 5: Were there delays in the construction caused by your part of the design process?

The responses were negative.

Question 6: If you answered yes in Question 5, what were the causes of these delays?

No response. 
Question 7: How did you perform quality control on the project, and what were the problems discovered during the quality checks?

The Design-Build teams tried to perform all the QC/QA on the projects as in any other project, but the tight schedule left no time for standard quality checking.

Question 8: Were there any communication problems between you and INDOT?

The respondents indicated there was some miscommunication between the involved parties.

Question 9: What could have been done to avoid these miscommunications?

The teams said that since the method is relatively new to INDOT, the paper flow needed definition.

Question 10: Was there enough INDOT personnel at the site to perform Quality Assurance?

The response to this question was unanimously affirmative.

Question 11: Do you think it is better if the Design-Build team controls the quality checks for the Design-Build projects?

Quality checks should be a team effort between INDOT and the Design-Build teams. One response said "the check of the contractor by INDOT should not be removed".

Question 12: Were there any design errors found during construction? All of the responses to this question said that errors were found during construction, which were readily corrected by the construction crews.

Question 13: Was INDOT able to supply you with all the right of way on time?

There were no right-of-way issues.

Question 14: Were all the environmental concerns dealt with by INDOT? There were no environmental problems. 
Question 15: Was the scope of the project clearly defined?

All the responses were affirmative saying that the scope was well defined.

Also the scope changes were insignificant during the construction phase and did not hinder the process.

Question 16: Were there changes in the scope of the project during construction?

The Design-Build teams commented that there were minor changes in the scope during construction.

Question 17: Did these changes cause delays or increase the cost of the project?

Minor changes in the scope added some minimal delays but there were no major concerns.

Question 18: Did these changes in the scope cause any friction with INDOT? All changes during construction caused some friction, but they were not a direct cause of the Design-Build process.

\subsubsection{Post Construction Phase}

Question 1: Do you think INDOT's selection process, for the successful bidder, is fair and good?

All the responses were affirmative.

Question 2: Are you satisfied with your performance in the Design-Build projects in comparison to Design-Bid-Build projects you participated?

The Design-Build team members were all satisfied with their performance in the Design-Build projects they participated in.

Question 3: Do you believe the cost of the Design-Build project would have been less if it were constructed using the Design-Bid-Build method?

The Design-Build teams said that the costs of the project remained about the same. They also commented that with Design-Build there is the added benefit of finishing the projects faster, thus reducing long-term costs.

Question 4: What are the advantages of Design-Build based on the projects you were involved? 
Some of the advantages that were mentioned by the Design-Build teams were cost reduction, encouraging participants to be more attentive to the job and design, and construction time is shortened.

Question 5: What are the disadvantages of Design-Build based on the projects you were involved?

Some of the disadvantages mentioned were the pressure that exists in the preparation of the construction documents by the designers, and the greater financial risk that a Design-Build team undertakes.

\subsection{Summary of Responses}

A comparative summary of responses from the three separate surveys is presented in Table 1, indicating the perception of INDOT personnel, consultants, and Design-Build teams regarding various aspects of DesignBuild projects. As can be expected, certain issues are critical to a particular group, while some are important to all. 


\section{Table 1}

Summary of Responses from INDOT, INDOT Consultants and Design-Build Teams Surveys

\begin{tabular}{|c|c|c|c|}
\hline & INDOT & INDOT Consultant & Design-Build Teams \\
\hline \multicolumn{4}{|l|}{ Initial Work } \\
\hline $\begin{array}{l}\text { 1. Which projects did you work } \\
\text { on? }\end{array}$ & $\begin{array}{l}\text { INDOT personnel replied } \\
\text { accordingly. }\end{array}$ & $\begin{array}{l}\text { The consultant replied } \\
\text { accordingly. }\end{array}$ & $\begin{array}{l}\text { Participants replied } \\
\text { accordingly. }\end{array}$ \\
\hline $\begin{array}{l}\text { 2. How long did it take INDOT } \\
\text { to complete the initial design } \\
\text { work, and what percentage of } \\
\text { design was performed by } \\
\text { INDOT and/or its consultant? }\end{array}$ & $\begin{array}{l}\text { There were no responses to this } \\
\text { question. }\end{array}$ & & \\
\hline $\begin{array}{l}\text { 3. Was the scope of the project } \\
\text { well defined? }\end{array}$ & $\begin{array}{l}\text { Four of the responses indicated } \\
\text { the scope was well defined, } \\
\text { while one indicated it was not. }\end{array}$ & The scope was well defined. & \\
\hline $\begin{array}{l}\text { 4. Where there any change } \\
\text { made in the scope of the project } \\
\text { after the Design-Build team } \\
\text { won the bid? }\end{array}$ & Some changes did occur. & Some changes did occur. & \\
\hline
\end{tabular}


Table 1 cont.

\begin{tabular}{|c|c|c|c|}
\hline Initial Work (cont.) & INDOT & INDOT Consultant & Design-Build Teams \\
\hline $\begin{array}{l}\text { 5. If 'Yes' in Question 4, please } \\
\text { explain reasons for change. }\end{array}$ & $\begin{array}{l}\text { Changes were made to improve } \\
\text { traffic flow and to aid } \\
\text { construction }\end{array}$ & & \\
\hline $\begin{array}{l}\text { 6. Did these changes cause } \\
\text { friction between INDOT and } \\
\text { the Design-Build teams? }\end{array}$ & No friction was caused. & & \\
\hline $\begin{array}{l}\text { 7. If changes were made in the } \\
\text { scope, did they cause any } \\
\text { delays in the design process } \\
\text { and your interaction with the } \\
\text { Design-Build team? }\end{array}$ & & $\begin{array}{l}\text { Changes did not affect the } \\
\text { Design-Build team to perform } \\
\text { the bid. }\end{array}$ & \\
\hline $\begin{array}{l}\text { 8. What was the overall cost of } \\
\text { the project? }\end{array}$ & & & $\begin{array}{l}\text { Participants replied } \\
\text { accordingly. }\end{array}$ \\
\hline \multicolumn{4}{|l|}{ Pre-bid } \\
\hline $\begin{array}{l}\text { 1. What percentage of design do } \\
\text { you consider necessary to be } \\
\text { performed by INDOT and/or its } \\
\text { consultants? }\end{array}$ & $\begin{array}{l}\text { Four responses indicated } 5 \%- \\
10 \% \text {, one response indicated } \\
40 \% \text {, while one indicated } \\
100 \% \text {. }\end{array}$ & $\begin{array}{l}\text { The level of design depends on } \\
\text { the size and complexity of the } \\
\text { job. }\end{array}$ & $\begin{array}{l}\text { The responses ranged from } \\
30 \% \text { to } 40 \% \text {. }\end{array}$ \\
\hline
\end{tabular}


Table 1 cont.

\begin{tabular}{|c|c|c|c|}
\hline Pre-bid (cont.) & INDOT & INDOT Consultant & Design-Build Teams \\
\hline $\begin{array}{l}\text { 2. In the projects that you } \\
\text { worked on, was the design } \\
\text { performed by INDOT and/or its } \\
\text { consultants adequate for the } \\
\text { bidding Design-Build teams to } \\
\text { complete their bid? }\end{array}$ & $\begin{array}{l}\text { Design work was adequate for } \\
\text { bidding. }\end{array}$ & & $\begin{array}{l}\text { All the participating firms } \\
\text { responded affirmatively. }\end{array}$ \\
\hline $\begin{array}{l}\text { 3. Was there enough time for } \\
\text { the bidding firms to complete } \\
\text { their bid? }\end{array}$ & $\begin{array}{l}\text { Three responses indicated that } \\
\text { there was enough time to } \\
\text { complete the bid, while two } \\
\text { responses indicated that there } \\
\text { was not enough time. }\end{array}$ & $\begin{array}{l}\text { The consultant replied that } \\
\text { there was enough time for the } \\
\text { teams to complete their bid. }\end{array}$ & $\begin{array}{l}\text { The responses were } \\
\text { affirmative, but changes in the } \\
\text { scope hindered their ability to } \\
\text { complete the bid. }\end{array}$ \\
\hline $\begin{array}{l}\text { 4. Do you believe that there is a } \\
\text { higher requirement for detailed } \\
\text { description of the design } \\
\text { preferences in Design-Build } \\
\text { projects compared to Design- } \\
\text { Bid-Build projects? }\end{array}$ & $\begin{array}{l}\text { Three of the responses } \\
\text { mentioned that there was a } \\
\text { higher need for a detailed } \\
\text { description. One response } \\
\text { indicated that only the scope } \\
\text { with no extensive design was } \\
\text { required. }\end{array}$ & $\begin{array}{l}\text { The INDOT consultant } \\
\text { indicated there was a higher } \\
\text { requirement for a detailed } \\
\text { description of the design. }\end{array}$ & \\
\hline
\end{tabular}


Table 1 cont.

\begin{tabular}{|c|c|c|c|}
\hline Pre-bid (cont.) & INDOT & INDOT Consultant & Design-Build Teams \\
\hline $\begin{array}{l}\text { 5. Were you involved in any } \\
\text { pre-bid design work for } \\
\text { Design-Build projects as an } \\
\text { INDOT consultant? }\end{array}$ & & $\begin{array}{l}\text { The consultant replied } \\
\text { accordingly. }\end{array}$ & \\
\hline $\begin{array}{l}\text { 6. In the pre-bid design work } \\
\text { you were involved was the } \\
\text { design performed by you } \\
\text { adequate for the Design-Build } \\
\text { teams to complete their bid? }\end{array}$ & & $\begin{array}{l}\text { The consultant replied } \\
\text { affirmatively. }\end{array}$ & \\
\hline \multicolumn{4}{|l|}{ Construction Phase } \\
\hline $\begin{array}{l}\text { 1. Were you satisfied with the } \\
\text { design performed by the } \\
\text { Design-Build teams? }\end{array}$ & $\begin{array}{l}\text { Four said they were satisfied } \\
\text { with the level of design; two } \\
\text { were not. }\end{array}$ & $\begin{array}{l}\text { The consultant was satisfied. } \\
\text { The more time available, the } \\
\text { better the design. }\end{array}$ & \\
\hline $\begin{array}{l}\text { 2. Did the design performed by } \\
\text { the Design-Build firms meet } \\
\text { INDOT specifications? }\end{array}$ & $\begin{array}{l}\text { All replied that the plans } \\
\text { satisfied INDOT standards and } \\
\text { specs. }\end{array}$ & No problems were mentioned. & \\
\hline $\begin{array}{l}\text { 3. Was there innovation in } \\
\text { Design? }\end{array}$ & $\begin{array}{l}\text { Some innovation was seen in } \\
\text { constructability issues. }\end{array}$ & $\begin{array}{l}\text { Some innovation was seen in } \\
\text { constructability issues. }\end{array}$ & \\
\hline
\end{tabular}


Table 1 cont.

\begin{tabular}{|c|c|c|c|}
\hline Construction Phase (cont.) & INDOT & INDOT Consultant & Design-Build Teams \\
\hline $\begin{array}{l}\text { 4. During construction did you } \\
\text { perform any inspection and } \\
\text { quality control on the projects? }\end{array}$ & $\begin{array}{l}\text { No problems were mentioned } \\
\text { on inspection. }\end{array}$ & $\begin{array}{l}\text { Consultant did not perform any } \\
\text { inspection. }\end{array}$ & \\
\hline $\begin{array}{l}\text { 5. Were there any errors found } \\
\text { during construction? }\end{array}$ & $\begin{array}{l}\text { Three responses said there were } \\
\text { some errors found; one said } \\
\text { there were considerable errors. }\end{array}$ & & $\begin{array}{l}\text { Errors were found, but they } \\
\text { were readily corrected. }\end{array}$ \\
\hline $\begin{array}{l}\text { 6. If 'yes' in Question 5, what } \\
\text { were the causes of these errors? }\end{array}$ & $\begin{array}{l}\text { Errors were due to oversight } \\
\text { and inexperience. }\end{array}$ & & \\
\hline $\begin{array}{l}\text { 7. Were there delays caused by } \\
\text { right-of-way issues? }\end{array}$ & $\begin{array}{l}\text { Right-of-way issues caused no } \\
\text { delays. }\end{array}$ & $\begin{array}{l}\text { Right-of-way issues caused no } \\
\text { delays. }\end{array}$ & $\begin{array}{l}\text { Right-of-way issues caused no } \\
\text { delays. }\end{array}$ \\
\hline $\begin{array}{l}\text { 8. Was there any } \\
\text { miscommunication between the } \\
\text { Design-Build team and } \\
\text { INDOT? }\end{array}$ & $\begin{array}{l}\text { One response indicated that } \\
\text { there was some, while three } \\
\text { responses indicated that the } \\
\text { miscommunication was } \\
\text { considerable. }\end{array}$ & $\begin{array}{l}\text { There was some } \\
\text { miscommunication in regards } \\
\text { to the interpretation of the plans }\end{array}$ & $\begin{array}{l}\text { The responses indicated that } \\
\text { there were some } \\
\text { miscommunications between } \\
\text { the involved parties. }\end{array}$ \\
\hline
\end{tabular}


Table 1 cont.

\begin{tabular}{|c|c|c|c|}
\hline Construction Phase (cont.) & INDOT & INDOT Consultant & Design-Build Teams \\
\hline $\begin{array}{l}\text { 9. What could have been done } \\
\text { to avoid these } \\
\text { miscommunications? }\end{array}$ & $\begin{array}{l}\text { Improvements in the Design- } \\
\text { Build method are required to } \\
\text { eliminate miscommunications. }\end{array}$ & Produce a better scope of work. & $\begin{array}{l}\text { The teams said that since the } \\
\text { method is relatively new to } \\
\text { INDOT, the paper flow needed } \\
\text { definition. }\end{array}$ \\
\hline $\begin{array}{l}\text { 10. Do you believe you had } \\
\text { enough personnel at the site for } \\
\text { Quality Assurance? }\end{array}$ & $\begin{array}{l}\text { There was enough personnel } \\
\text { for Quality Assurance. }\end{array}$ & & $\begin{array}{l}\text { The response was unanimously } \\
\text { affirmative. }\end{array}$ \\
\hline $\begin{array}{l}\text { 11. Do you think that it is better } \\
\text { if the control of the quality } \\
\text { checks fall on the Design-Build } \\
\text { teams? }\end{array}$ & $\begin{array}{l}\text { All responded that having the } \\
\text { Design-Build teams perform all } \\
\text { quality checks is not a good } \\
\text { idea. }\end{array}$ & & $\begin{array}{l}\text { Quality checks are a team } \\
\text { process and both the owner and } \\
\text { the Design-Builder should be } \\
\text { involved. }\end{array}$ \\
\hline $\begin{array}{l}\text { 12. Do you think it is good that } \\
\text { INDOT had fewer } \\
\text { responsibilities for inspection, } \\
\text { testing and quality control? }\end{array}$ & $\begin{array}{l}\text { The responses stated that there } \\
\text { was less paperwork, but the } \\
\text { Design-Build job was treated } \\
\text { like any other job. }\end{array}$ & & \\
\hline
\end{tabular}


Table 1 cont.

\begin{tabular}{|c|c|c|c|}
\hline Construction Phase (cont.) & INDOT & INDOT Consultant & Design-Build Teams \\
\hline $\begin{array}{l}\text { 13. Do you believe the Design- } \\
\text { Build team had tendencies to } \\
\text { assume that the plans were only } \\
\text { a guideline and field changes } \\
\text { could be made without the } \\
\text { review of the design by their } \\
\text { design personnel? }\end{array}$ & $\begin{array}{l}\text { Three responded that the Design- } \\
\text { Build team did not have the } \\
\text { tendency, while three indicated } \\
\text { that the Design-Build designer } \\
\text { would change the designs } \\
\text { according to the contractor's } \\
\text { request. }\end{array}$ & & \\
\hline $\begin{array}{l}\text { 14. Were there any } \\
\text { misunderstandings between } \\
\text { INDOT consultants and } \\
\text { Design-Build teams? }\end{array}$ & & $\begin{array}{l}\text { There were some } \\
\text { misunderstandings caused by } \\
\text { misinterpretation of plans, the } \\
\text { scope and specifications. }\end{array}$ & \\
\hline $\begin{array}{l}15 . \text { Were these } \\
\text { misunderstandings caused by } \\
\text { pre-bid design problems? }\end{array}$ & & $\begin{array}{l}\text { Some misunderstandings were } \\
\text { caused by pre-bid design. }\end{array}$ & \\
\hline
\end{tabular}


Table 1 cont.

\begin{tabular}{|c|c|c|c|}
\hline Construction Phase (cont.) & INDOT & INDOT Consultant & Design-Build Teams \\
\hline $\begin{array}{l}\text { 16. Was there any problem for } \\
\text { you to complete the design, of } \\
\text { the Design-Build project, } \\
\text { according to INDOT's } \\
\text { specifications? }\end{array}$ & & & $\begin{array}{l}\text { All responses were affirmative } \\
\text { since they were always pressed } \\
\text { for time. }\end{array}$ \\
\hline $\begin{array}{l}\text { 17. Did construction meet the } \\
\text { design requirements? }\end{array}$ & & & All responses were affirmative. \\
\hline $\begin{array}{l}\text { 18. Was there any innovative } \\
\text { design or construction method } \\
\text { employed in the Design-Build } \\
\text { project you worked on? }\end{array}$ & & & $\begin{array}{l}\text { Innovation was introduced, but } \\
\text { was not always accepted by } \\
\text { INDOT. }\end{array}$ \\
\hline $\begin{array}{l}\text { 19. Was there sufficient time } \\
\text { for you to complete design? }\end{array}$ & & & $\begin{array}{l}\text { The Design-Build teams said } \\
\text { that they completed the design, } \\
\text { but they were always pressed } \\
\text { for time. }\end{array}$ \\
\hline $\begin{array}{l}\text { 20. Were there delays in the } \\
\text { construction caused by your } \\
\text { part of the design process? }\end{array}$ & & & The responses were negative. \\
\hline
\end{tabular}


Table 1 cont.

\begin{tabular}{|c|c|c|c|}
\hline Construction Phase (cont.) & INDOT & INDOT Consultant & Design-Build Teams \\
\hline $\begin{array}{l}\text { 21. If you answered yes in } \\
\text { Question 5, what were the } \\
\text { causes of these delays? }\end{array}$ & & & No response was given. \\
\hline $\begin{array}{l}\text { 22. Were all the environmental } \\
\text { concerns dealt with by } \\
\text { INDOT? }\end{array}$ & & & $\begin{array}{l}\text { There were no environmental } \\
\text { concerns. }\end{array}$ \\
\hline $\begin{array}{l}\text { 23. Was the scope of the } \\
\text { project clearly defined? }\end{array}$ & & & The scope was clearly defined. \\
\hline $\begin{array}{l}\text { 24. Were there changes in the } \\
\text { scope of the project made } \\
\text { during construction? }\end{array}$ & & & $\begin{array}{l}\text { There were minor changes in } \\
\text { the scope during construction. }\end{array}$ \\
\hline $\begin{array}{l}\text { 25. Did these changes cause } \\
\text { delays or increase in the cost of } \\
\text { the project? }\end{array}$ & & & $\begin{array}{l}\text { Some minimal delays were } \\
\text { observed. }\end{array}$ \\
\hline $\begin{array}{l}\text { 26. Did these changes in the } \\
\text { scope cause any friction } \\
\text { between you and the INDOT? }\end{array}$ & & & $\begin{array}{l}\text { Changes caused some friction, } \\
\text { but they were not a direct result } \\
\text { of Design-Build. }\end{array}$ \\
\hline
\end{tabular}


Table 1 cont.

\begin{tabular}{|c|c|c|c|}
\hline Post Construction Phase & INDOT & INDOT Consultant & Design-Build Teams \\
\hline $\begin{array}{l}\text { 1. Are you satisfied with the } \\
\text { performance of Design-Build } \\
\text { projects in regards to the } \\
\text { overall quality of the projects? }\end{array}$ & $\begin{array}{l}\text { Three said that they were } \\
\text { satisfied with the project; three } \\
\text { were not. }\end{array}$ & The consultant was satisfied. & \\
\hline $\begin{array}{l}\text { 2. Were the projects delivered } \\
\text { in adequate time or were there } \\
\text { delays? }\end{array}$ & $\begin{array}{l}\text { Five responded that the project } \\
\text { was delivered in adequate time; } \\
\text { one said that there were delays. }\end{array}$ & & \\
\hline $\begin{array}{l}\text { 3. Were these delays caused by } \\
\text { construction or by the pre-bid } \\
\text { design process? }\end{array}$ & $\begin{array}{l}\text { Delays were caused by } \\
\text { construction faults. }\end{array}$ & There was no valid response. & \\
\hline $\begin{array}{l}\text { 4. In comparison to projects } \\
\text { performed by the Design-Bid- } \\
\text { Build method, were there more } \\
\text { or less delays in the Design- } \\
\text { Build projects? }\end{array}$ & $\begin{array}{l}\text { One indicated that here were } \\
\text { fewer delays since the } \\
\text { contractor wanted to finish } \\
\text { early; another said there were } \\
\text { more delays. }\end{array}$ & & \\
\hline
\end{tabular}


Table 1 cont.

\begin{tabular}{|c|c|c|c|}
\hline $\begin{array}{c}\text { Post Construction Phase } \\
\text { (cont.) }\end{array}$ & INDOT & INDOT Consultant & Design-Build Teams \\
\hline $\begin{array}{l}\text { 5. Do you think the Design- } \\
\text { Build method costs less than } \\
\text { the Design-Bid-Build } \\
\text { approach? }\end{array}$ & $\begin{array}{l}\text { All said that Design-Build } \\
\text { projects cost more. }\end{array}$ & & \\
\hline $\begin{array}{l}\text { 6. Based on your experiences, } \\
\text { is Design-Build a good } \\
\text { alternative to the Design-Bid- } \\
\text { Build method? }\end{array}$ & $\begin{array}{l}\text { One said the Design-Build } \\
\text { method is a good alternative in } \\
\text { getting the jobs done faster; } \\
\text { two said there were many } \\
\text { corners cut in design and many } \\
\text { mistakes were found. }\end{array}$ & $\begin{array}{l}\text { Design-Build is a good } \\
\text { alternative. }\end{array}$ & \\
\hline $\begin{array}{l}\text { 7. What are the advantages of } \\
\text { Design-Build based on the } \\
\text { projects you were involved? }\end{array}$ & There was a lot of time saved. & There is a lot of time saved. & $\begin{array}{l}\text { Cost reduction and project } \\
\text { completion time reduced. }\end{array}$ \\
\hline $\begin{array}{l}\text { 8. What are the disadvantages } \\
\text { of Design-Build based on the } \\
\text { projects you were involved? }\end{array}$ & $\begin{array}{l}\text { Poor quality in design, } \\
\text { confusion among participants. }\end{array}$ & $\begin{array}{l}\text { The reduced time frame to } \\
\text { complete the initial design } \\
\text { work. }\end{array}$ & $\begin{array}{l}\text { Pressure that exists in the } \\
\text { preparation of the construction } \\
\text { documents and the greater } \\
\text { financial risk. }\end{array}$ \\
\hline
\end{tabular}


Table 1 cont.

\begin{tabular}{|l|l|l|l|}
\hline \multicolumn{1}{|c|}{$\begin{array}{c}\text { Post Construction Phase } \\
\text { (cont.) }\end{array}$} & INDOT & Design-Build Teams \\
\hline $\begin{array}{l}\text { 9. Do you think INDOT's } \\
\text { selection process, for the } \\
\text { successful bidder, is fair and } \\
\text { good? }\end{array}$ & & All responses were affirmative. \\
\hline $\begin{array}{l}\text { 10. Are you satisfied with your } \\
\text { performance in the Design- } \\
\text { Build projects in comparison to } \\
\text { other Design-Bid-Build } \\
\text { projects you participated in? }\end{array}$ & & & All responses were affirmative. \\
\hline $\begin{array}{l}\text { 11. Do you believe the cost of } \\
\text { the Design-Build project would } \\
\text { have been less if it were } \\
\text { constructed using the Design- } \\
\text { Bid-Build method? }\end{array}$ & & & \\
\hline
\end{tabular}




\section{Survey of ICI and ACEC of Indiana Members}

After the initial data was gathered from the first set of surveys, two more questionnaires were developed with the assistance of the Study Advisory Committee. The first was sent to the members of Indiana Constructors Inc. (ICI) and the second to the members of American Council of Engineering Companies (ACEC) of Indiana.

These two groups were chosen to participate in the survey because their members perform most of the design and construction of highway projects in Indiana. Thirty responses were received from the ICI members and ten responses were received from ACEC of Indiana consultants. Both questionnaires are shown in Appendix C. Responses are discussed in the following sections.

\subsection{Responses of the ICI Members}

The survey questionnaire was distributed to the ICI members through the ICI office and the responses were received directly by the study team. There are 71 member organizations in ICI. Thirty (30) of the 71 responded to the survey. These graphs represent their responses.

Question 1: Are you aware of INDOT's Design-Build program?

All the firms replied positively.

Question 2: Did you ever consider participating in any Design-Build highway project?

Twenty-one (70\%) of the replies were positive and nine $(30 \%)$ were negative, as shown in Figure 2.

Question 3: Have you bid on an INDOT Design-Build project? If 'Yes', explain any problems you have had with the bidding process.

There were eleven $(36.7 \%)$ positive responses and nineteen $(63.3 \%)$ negative as indicated in Figure 3. A summary of the problems mentioned by the respondents about the bidding process is given below:

- Subcontractors do not get complete specifications and plans because the main contractors are afraid of losing confidential advantages. 
- Not enough time for bidding. INDOT was coming back with revisions.

- Plans were generally not complete and the subcontractors had a lot of unknowns.

- Subcontractors were not able to determine the true scope.

- Engineers estimate does not reflect the scope of work to be performed, and INDOT does not have a way of accurately developing quantities.

- Very expensive staff time and design cost outlay to prepare a bid.

- Variance in scope of service in the bids presented.

- INDOT was unwilling to consider or evaluate value-engineering considerations.

- Project award based on price with no consideration of scores achieved on technical proposals.

- Ambiguous scope documents.

- Bid dates too close to start dates to allow for proper pre-job planning and procurement.

- Specifications are method based as opposed to performance based, thereby restricting innovations.

- Stipends inadequate to offset substantial design costs to contractors.

\section{Number of Responses $=\mathbf{3 0}$}
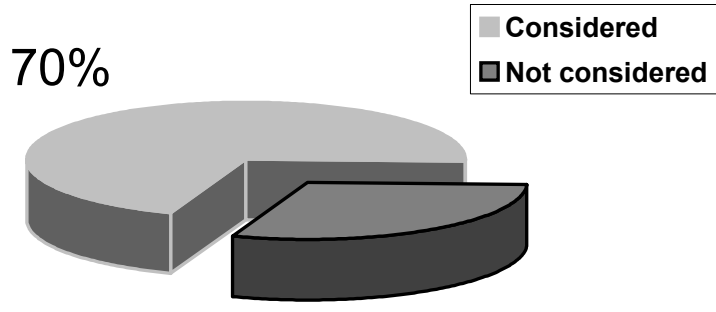

$30 \%$

Figure 2. ICI members considering participation in Design-Build projects 


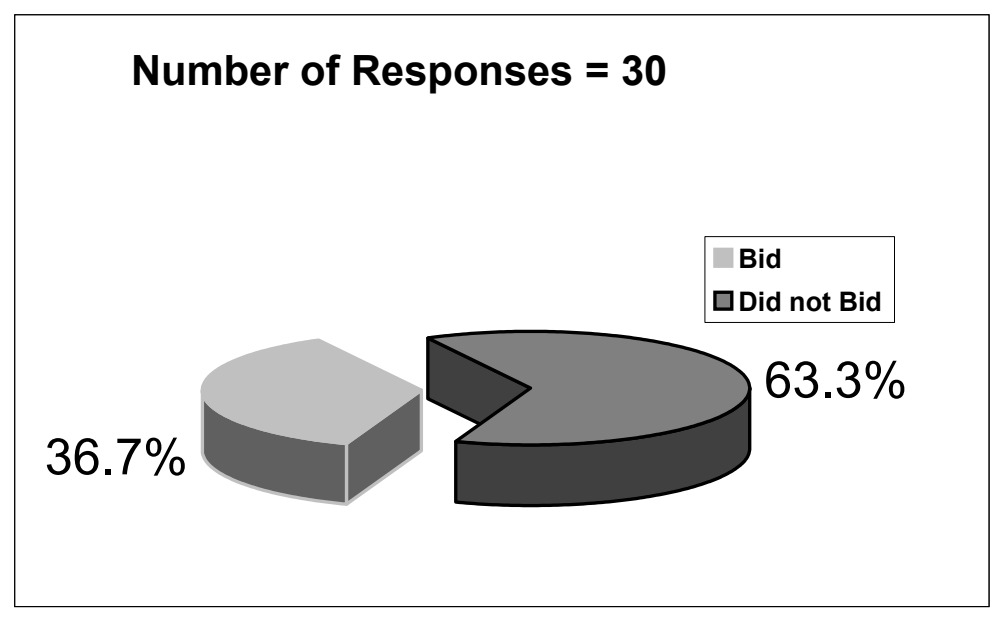

Figure 3. ICI member participation in INDOT Design-Build projects

Question 4: Do you think that you will be interested in participating in any INDOT Design-Build project in the future? If 'Yes' what types of projects will you be interested in participating in? If 'No', why not?

From the thirty responses, fifteen (50.0\%) responded affirmatively, and fifteen $(50.0 \%)$ responded negatively, as shown in Figure 4 . The concerns that the participants expressed are summarized below:

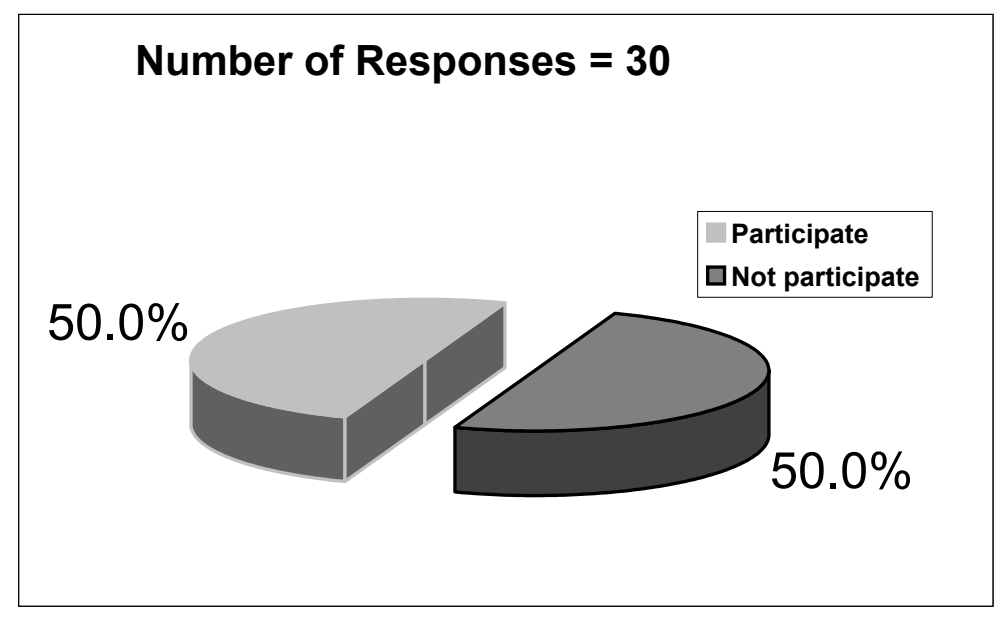

Figure 4. ICI members considering participation in INDOT Design-Build projects in the future 
- Design-Build projects that were put out for bidding so far in Indiana are large and eliminate most of Indiana's small contractors.

- Some contracting companies expressed that they do not have the staff to prepare and participate on jobs that require extensive office work

Question 5: This question asked the ICI members to rate several advantages of the Design-Build process from "Strongly Agree" to "Strongly Disagree".

a. Reduced Duration of Construction - Design-Build decreases the overall project completion time as compared to Design-Bid-Build since design and construction periods overlap, and redesign is mostly eliminated. Thirty responses were received. The breakdown of the responses are shown in Figure 5.

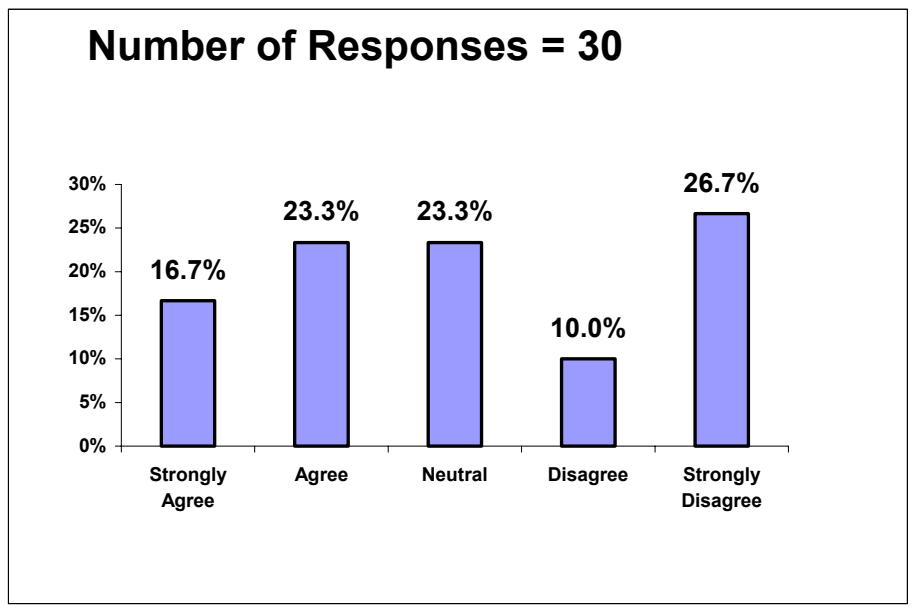

Figure 5. ICI member opinions: Does Design-Build reduce duration of construction?

b. Contractibility/Innovation - Design-Build introduces construction knowledge into design early in the process.

Twenty-nine of the 30 respondents answered this item, and the responses are shown in Figure 6. 


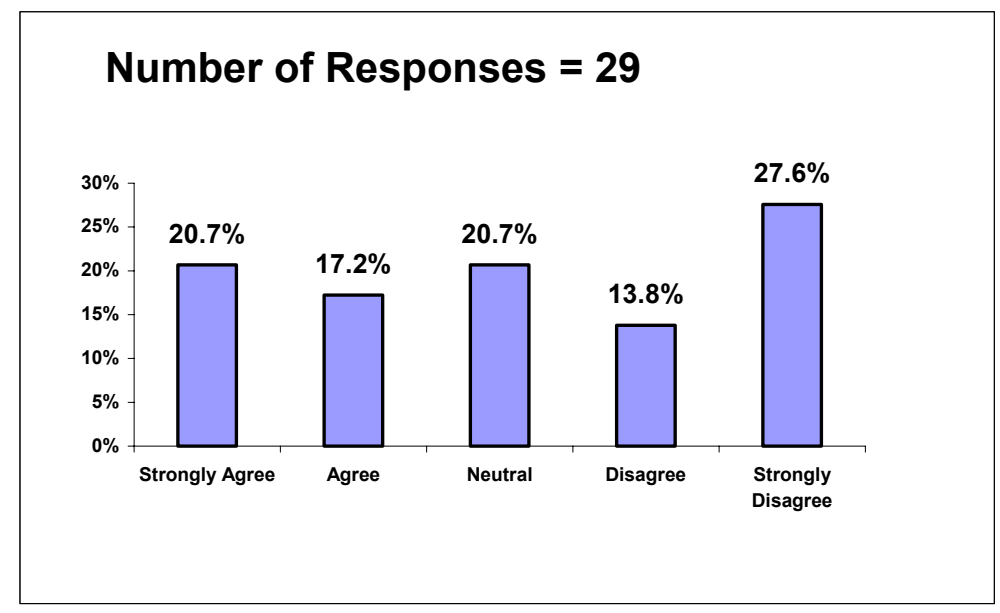

Figure 6. ICI member opinions: Does Design-Build introduce innovation and improve constructability?

c. Reduce Cost-Design-Build decreases the overall project cost as compared to Design-Bid-Build. Project costs are identified far earlier, allowing for budgetary concerns to be addressed early. Also value engineering and constructability are utilized since designer and contractor work as a team.

Twenty-nine responses were received and Figure 7 shows the distribution.

d. Single Point Responsibility - The Design-Build team has full responsibility for the outcome of the project. The contractor and the designer are allied and work together as a team, giving the owner the opportunity to focus on the scope and needs definition rather than coordinating the design aspect of the job with the construction aspect. Thirty responses were received and Figure 8 shows the response distribution. 


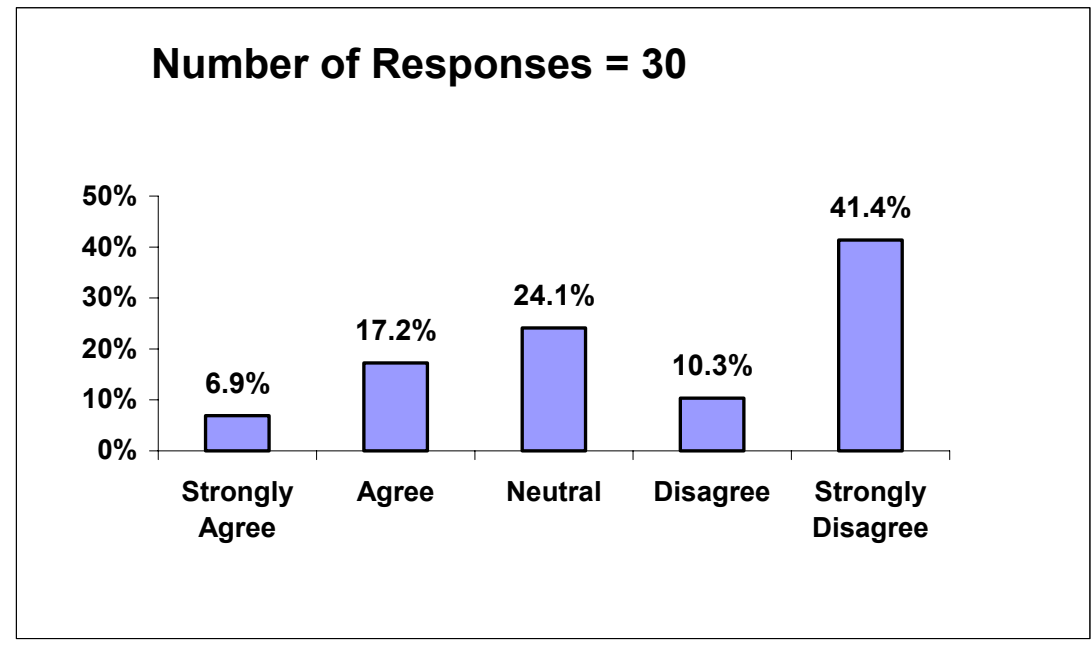

Figure 7. ICI member opinions: Does Design-Build reduce construction costs?

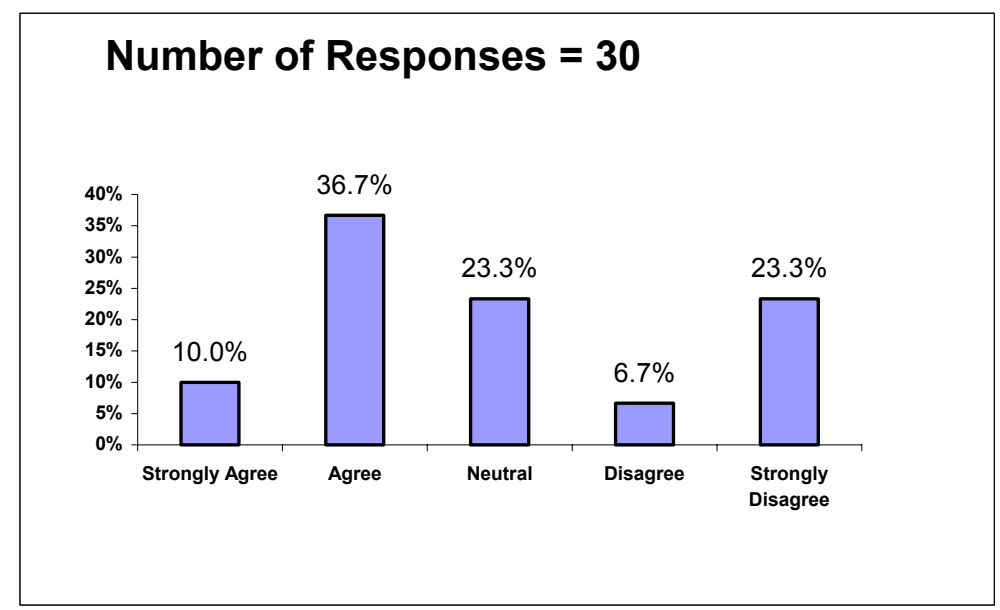

Figure 8. ICI member opinions: Is there a single point responsibility with Design-Build?

e. Continuity between Designer and Constructor - In Design-Build projects, the same entity has the expertise to design the project and construct it. Thirty responses were received and Figure 9 shows the distribution. 


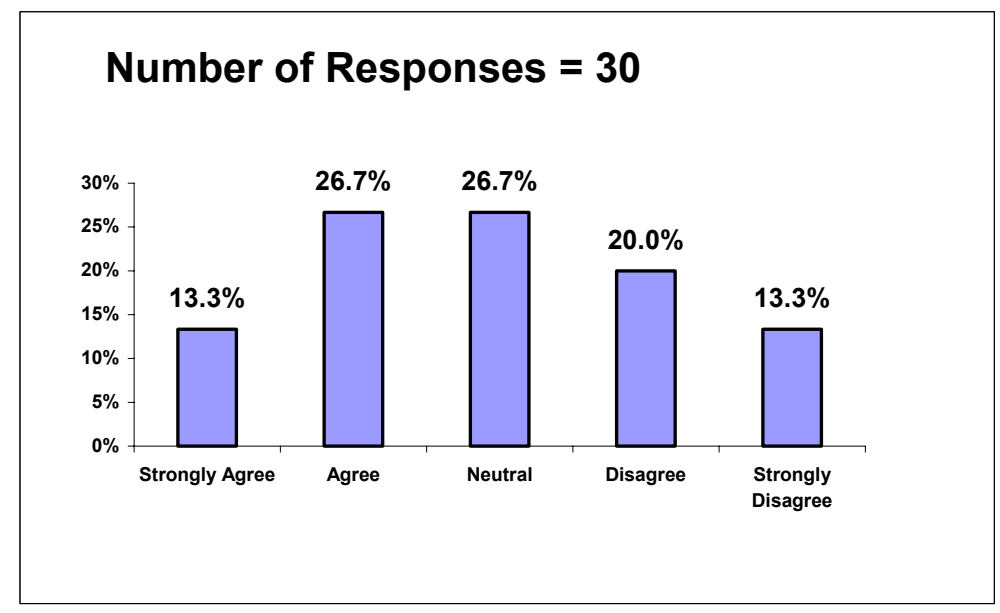

Figure 9. ICI member opinions: Is there continuity between construction and design in Design-Build?

f. In Design-Build there is less misunderstanding between the parties involved

Thirty responses were received and Figure 10 shows the distribution.

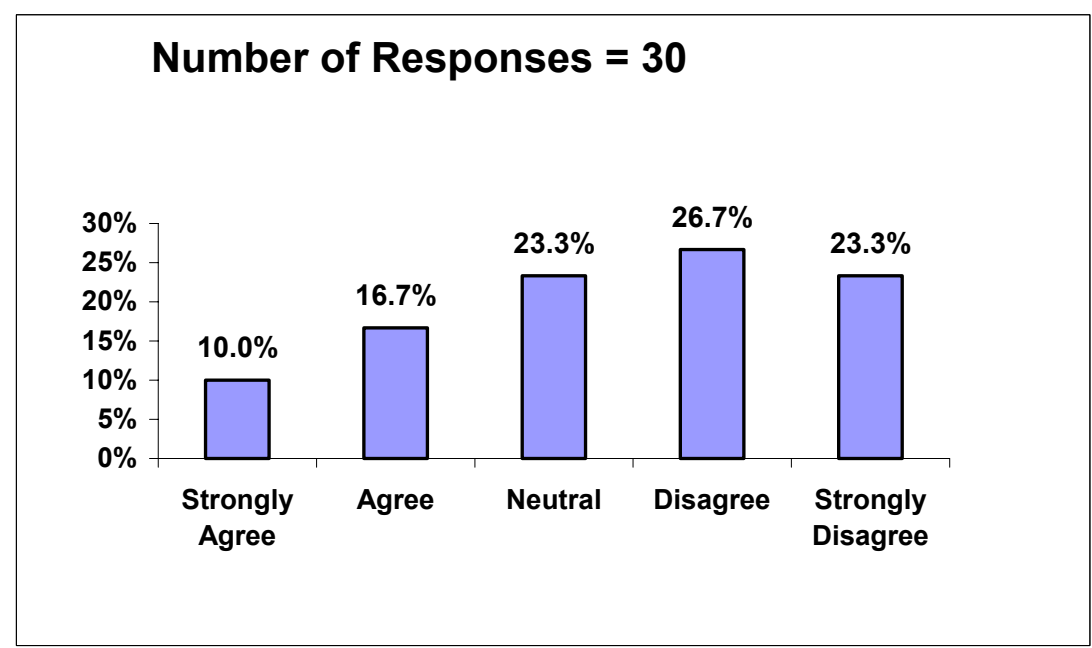

Figure 10. ICI member opinions: Are there fewer misunderstandings between parties in Design-Build?

Question 6: Are there other advantages of the Design-Build method for highway projects, in comparison to the Design-Bid-Build method that are not mentioned in Question 5?

The advantages mentioned by the ICI members are summarized below: 
- Large jobs provide the best opportunities for efficiencies and cost savings that can accrue due to Design-Build innovations.

- Relationships and communications between designer, contractor and INDOT are substantially improved which result in a higher quality product and reduced number of claims.

- More ideas from experienced contractors expedite design problem solutions.

Question 7: This question asked ICI members to rate several disadvantages of the Design-Build process from "Strongly Agree" to "Strongly Disagree".

a. It has been observed that Design-Build restricts competition due to the elimination of small and medium contractors because they cannot afford the risk associated with the design liabilities and the extended project liability inherent with Design-Build.

Thirty responses were received and Figure 11 shows the response distribution.

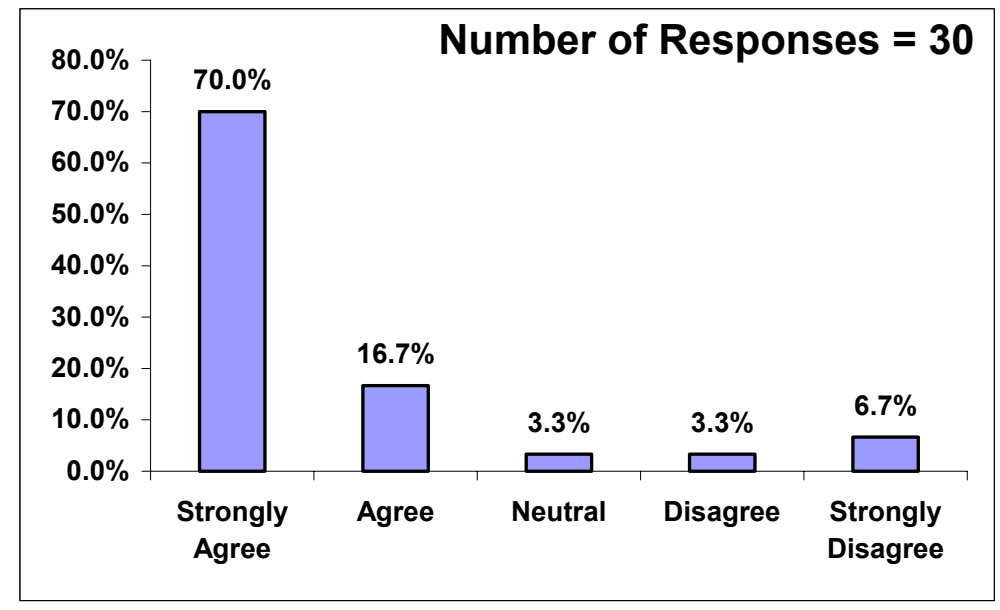

Figure 11. ICI member opinions: Does Design-Build limit competition?

b. The project cost is greater because of extra costs or claims incurred when delays occur in the construction phase, due to the need to resolve permitting and environmental issues or to solidify owner preferences. 
Thirty responses were received and Figure 12 shows the response distribution.

c. The project may require longer completion time with the Design-Build method, particularly if the scope of work or permitting issues are unresolved.

Thirty responses were received and Figure 13 shows the distribution.

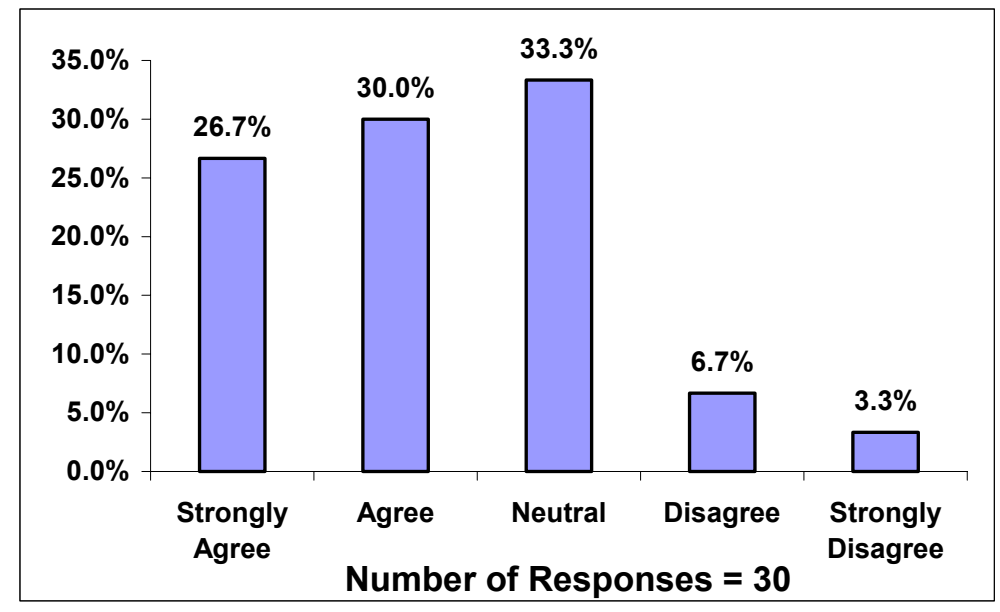

Figure 12. ICI member opinions: Does Design-Build increase construction costs?

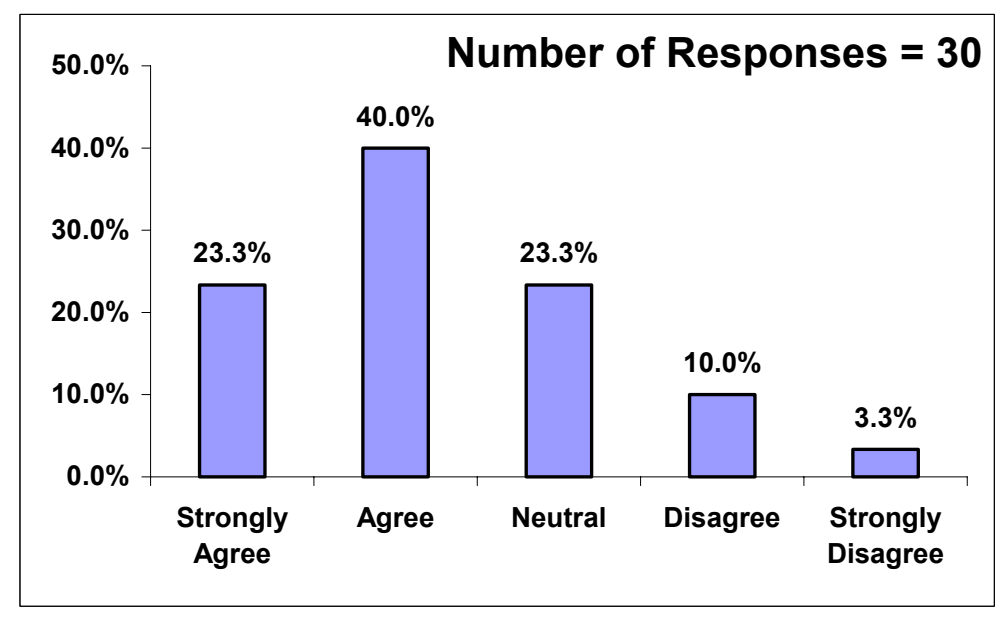

Figure 13. ICI member opinions: Do Design-Build projects take longer to construct? 
d. The magnitude of liability risk to the designer may discourage participation by highly qualified designers. Given the relatively small percentage of the overall project that his or her services represent, the risk may far outweigh the potential return. As a member of the designbuild team, the designer is linked to the construction process to a greater degree than under design-bid-build.

Thirty responses were received and the responses are shown in Figure 14.

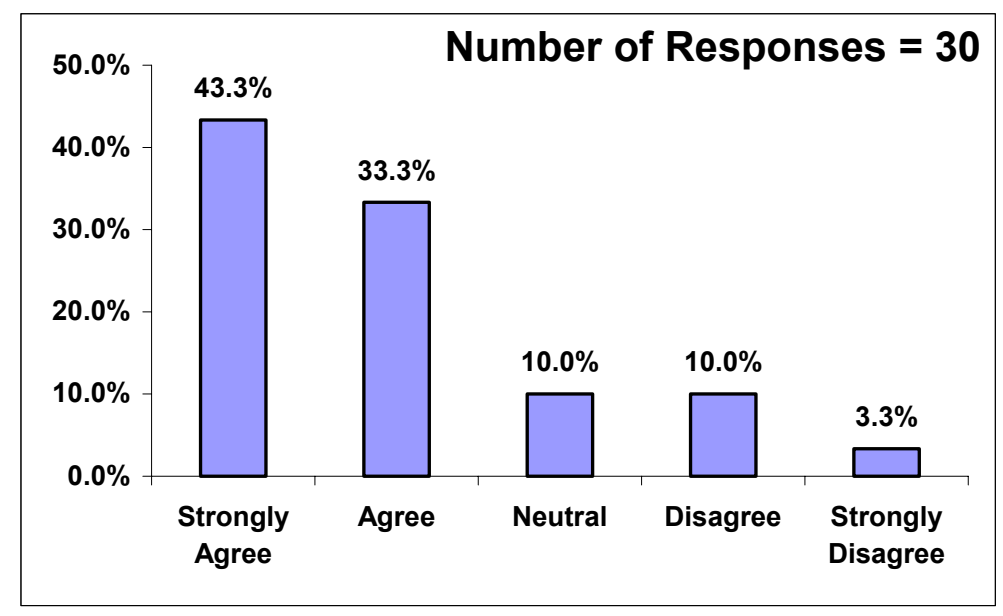

Figure 14. ICI member opinions: Does Design-Build discourage designers to participate due to higher risks involved?

e. Design decisions may be determined or inappropriately influenced by team members other than the designer. This is more likely to occur when a non-designer is the lead on the design-build team.

Thirty responses were received and they are shown in Figure 15.

$f$. The designer may be selected on the basis of price rather than qualifications, potentially compromising the public health, safety, and welfare

Thirty responses were received and they are shown in Figure 16. 


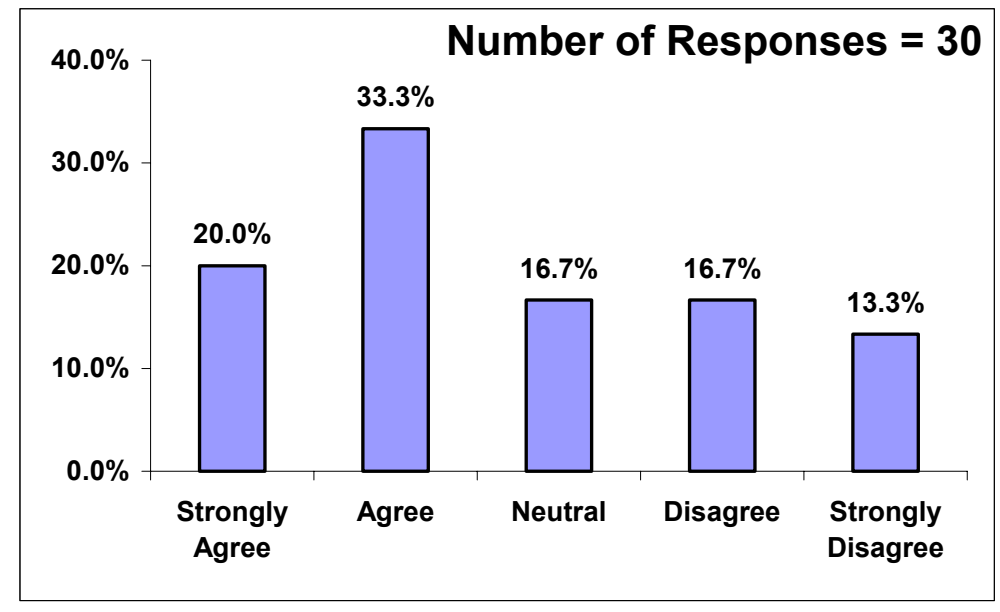

Figure 15. ICI member opinions: Are design decisions in Design-Build not always influenced by the designer?

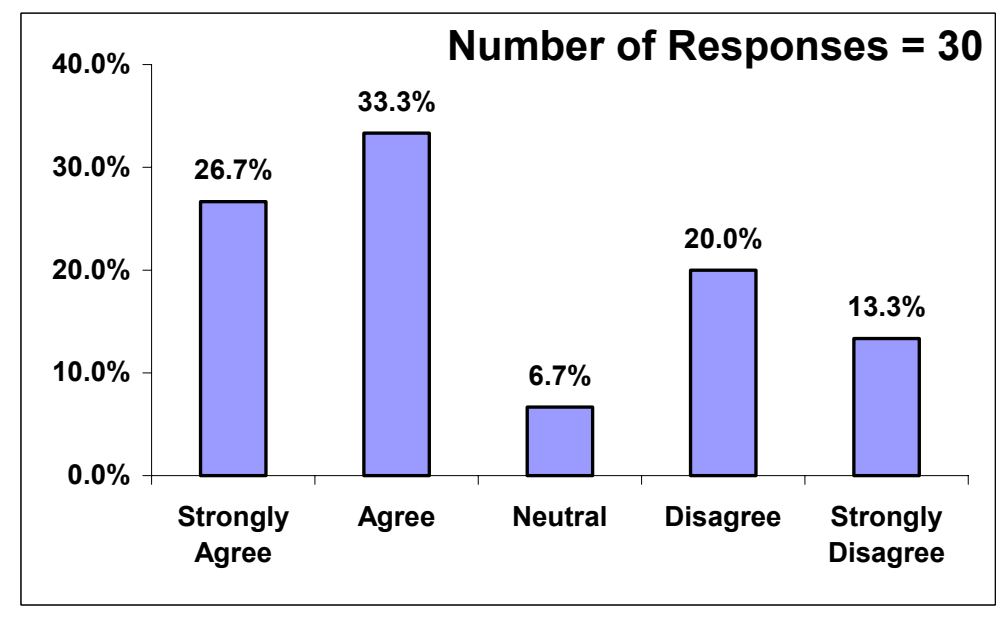

Figure 16. ICI member opinions: Could the Design-Build designer be chosen on the basis of price rather than qualifications?

Question 8: Are there disadvantages of the Design-Build method for highway projects, in comparison to the Design-Bid-Build method that were not mentioned in Question 7?

Below is a summary of thirty responses.

- Low stipends in relation to design costs discourage both qualified contractors and designers. 
- Owner loses objective professional representation he would get with a consultant during construction, since the consultant is technically a subcontractor.

- There is a lack of willing designers to participate in Design-Build projects

- There is a lot of manpower and resources that are wasted from the design side if a particular Design-Build team is not successful.

- Design-Build encourages the cheapest design within the scope of the project, which can compromise safety and quality.

- Work is forced to proceed too fast causing conflicts between the prime contractor and subcontractors.

- Projects in Indiana are seen to be going to out-of-state firms.

Question 9: Answer the following questions only if you participated in any Design-Build highway projects, not necessarily in Indiana.

a. Did the Design-Build method encourage innovation? If yes what innovation was proposed?

In regards to innovation that was introduced thirty responses were received and they were grouped as shown below:

- $\quad$ Limited innovation was encouraged and no more than Design-BidBuild project.

- $\quad$ Political considerations or established codes prohibited much potential innovation.

- $\quad$ INDOT did not accept innovations, instead they indicated to submit them after the bid as a "Value Engineering Proposal".

- Innovation was discouraged due to strict design criteria.

b. How far should the design for a particular project be developed before it is given out for bidding?

The firms that participated in the report indicated that a good scope should be provided and design of up to $30 \%-40 \%$. 
Question 10: Please address any other items that you feel are relevant to the issue of Design-Build versus Design-Bid-Build.

The responses of the Design-Build teams addressed several issues. Many of the firms expressed their concerns in regard to the size of the projects that have been let. Smaller firms cannot undertake the risks and the management requirements that are present in the bidding stage of Design-Build, and as a result they do not get involved with the process. Another item that smaller firms addressed was the fact that there are not many consultants willing and able to participate.

Other issues mentioned were directed towards INDOT's Design-Build process. Contractors would like INDOT to have a better definition of what is expected in the technical proposal. Other contractors expressed their dislike in awarding the contract solely on price. They would like to see the quality of the finished product, the safety provisions and the time of project completion to be included in the evaluation of a bid.

Question 11: Would you be interested in participating in a follow-up personal interview?

The responses are shown in Figure 17.

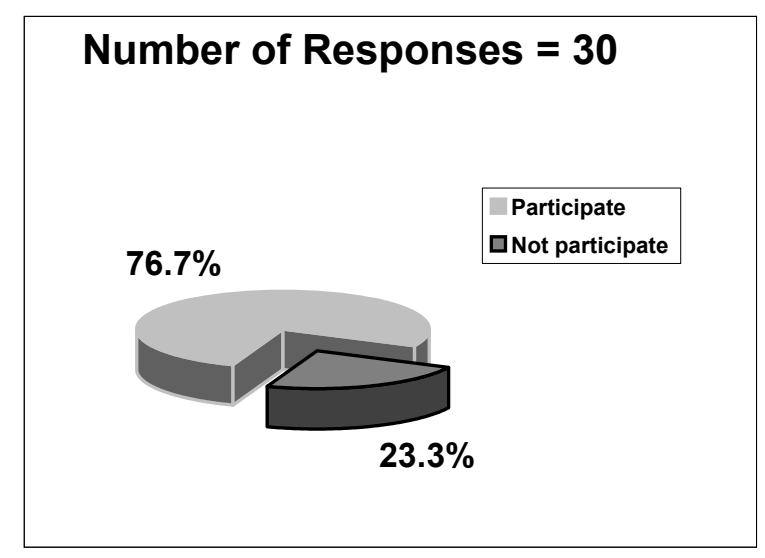

Figure 17. Willingness of ICI respondents for a follow-up interview 


\subsection{Responses of the ACEC of Indiana Members}

All members of the American Council of Engineering Companies (ACEC) of Indiana were contacted through the ACEC of Indiana office and the responses were received directly by the study team. There are 92 member organizations in ACEC of Indiana. The following is a summary of the ten responses received.

Question 1: Are you aware of INDOT's Design-Build program?

All the firms responding said they were aware of the Design-Build program.

Question 2: Did you ever consider participating in any Design-Build highway project? (Not necessarily with INDOT)

Eight $(80 \%)$ of the replies to this question were positive and two $(20 \%)$ were negative.

Question 3: Did you ever participate in an INDOT Design-Build project?

Five $(50.0 \%)$ of the responses to this question replied affirmatively, while five $(50.0 \%)$ replied negatively.

Question 4: Do you think you will be interested in participating in any INDOT Design-Build project in the future? If 'Yes' what types of projects will you be interested in participating in. If 'No' why not?

Five $(50.0 \%)$ replied affirmatively, while five (50.0\%) replied negatively. The firms that replied negatively expressed the following views about DesignBuild:

- The consultant in a Design-Build project has a lot to lose and very little to gain.

- The process utilizes a great deal of design time and most of the work is never utilized.

Question 5: This question asked the ACEC of Indiana members to rate several advantages of the Design-Build process from "Strongly Agree" to "Strongly Disagree". 
a. Reduced Duration of Construction-Design-Build decreases the overall project completion time as compared to Design-Bid-Build since design and construction periods overlap, and redesign is mostly eliminated.

Ten responses were received and a graphical representation of the results is shown in Figure 18.

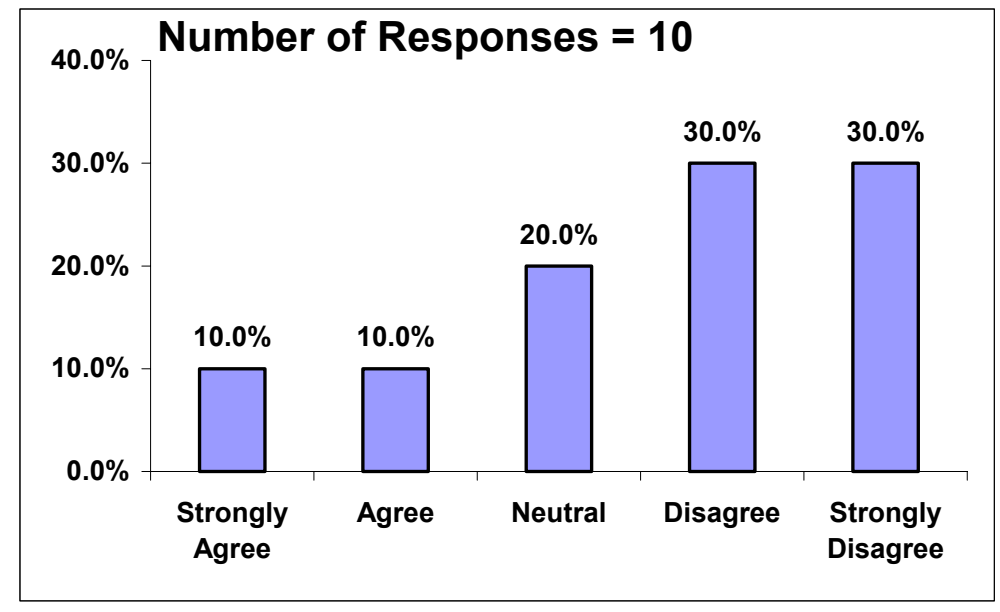

Figure 18. ACEC of Indiana member opinions: Does Design-Build reduce duration of construction?

b. Constructability/Innovation - Design-Build introduces construction knowledge into design early in the process.

Ten responses were received and a graphical representation of the results is shown in Figure 19.

c. Reduce Cost-Design-Build decreases the overall project cost as compared to Design-Bid-Build. Project costs are identified far earlier, allowing for budgetary concerns to be addressed early. Also value engineering and constructability are utilized since designer and contractor work as a team.

Ten responses were received, and a graphical representation of the results is shown in Figure 20. 


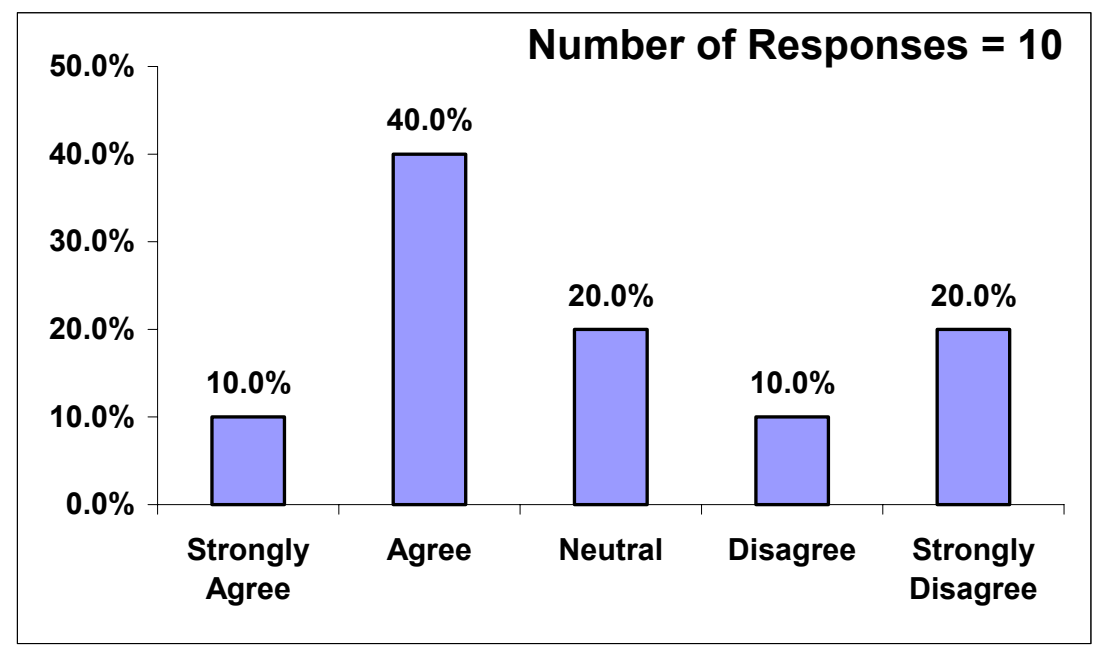

Figure 19. ACEC of Indiana member opinions: Does Design-Build introduce innovation and improve constructability?

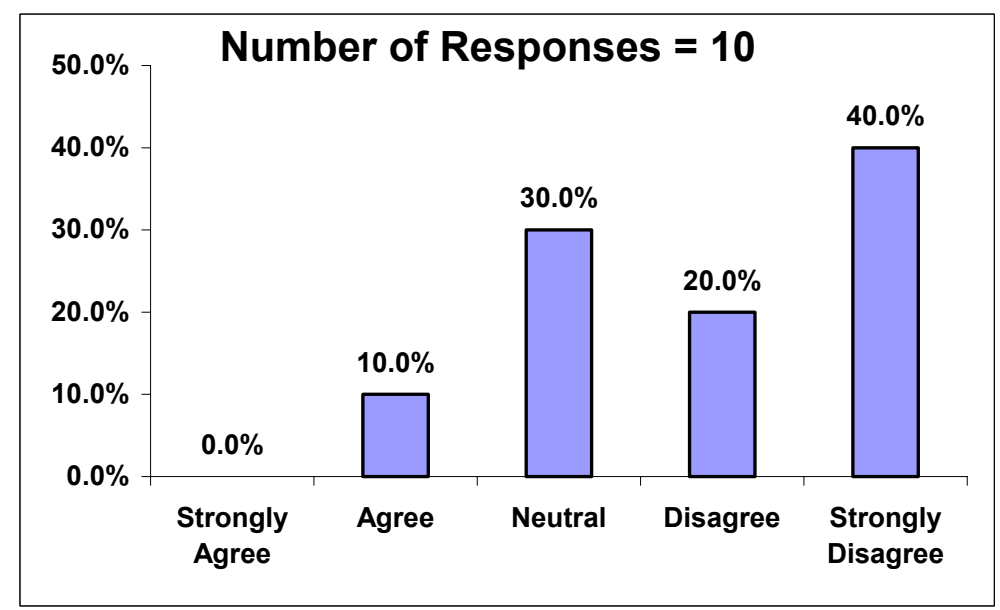

Figure 20. ACEC of Indiana member opinions: Does Design-Build reduce construction costs?

d. Single Point Responsibility - The Design-Build team has full responsibility for the outcome of the project. The contractor and the designer are allied and work together as a team, giving the owner the opportunity to focus on the scope and needs definition rather than coordinating the design aspect of the job with the construction aspect. Ten responses were received and a graphical representation of the results is shown in Figure 21. 


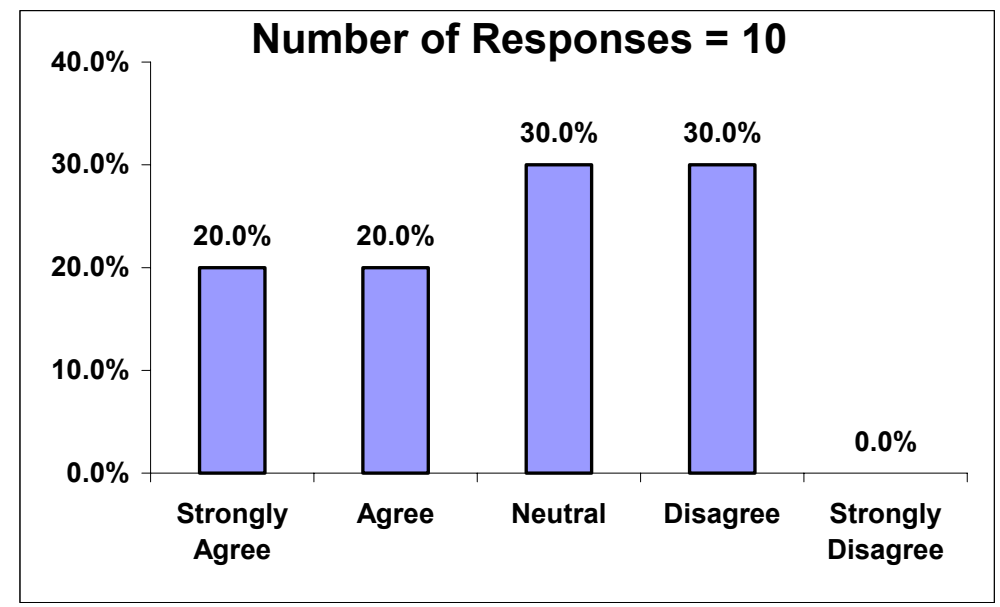

Figure 21. ACEC of Indiana member opinions: Does the Design-Build team have full responsibility for the outcome of the project?

e. Continuity between Designer and Constructor - In Design-Build projects, the same entity has the expertise to design the project and construct it. Ten responses were received and a graphical representation of the results is shown in Figure 22.

f. In Design-Build projects, there is less misunderstanding between the parties involved.

Ten responses were received and a graphical representation of the results is shown in Figure 23. 


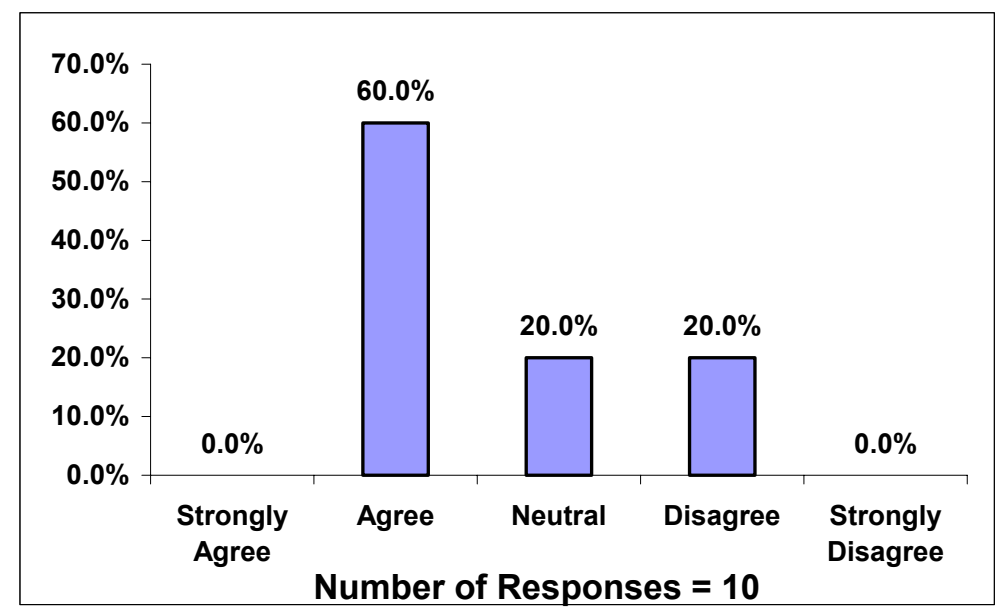

Figure 22. ACEC of Indiana member opinions: Is there continuity between construction and design in Design-Build?

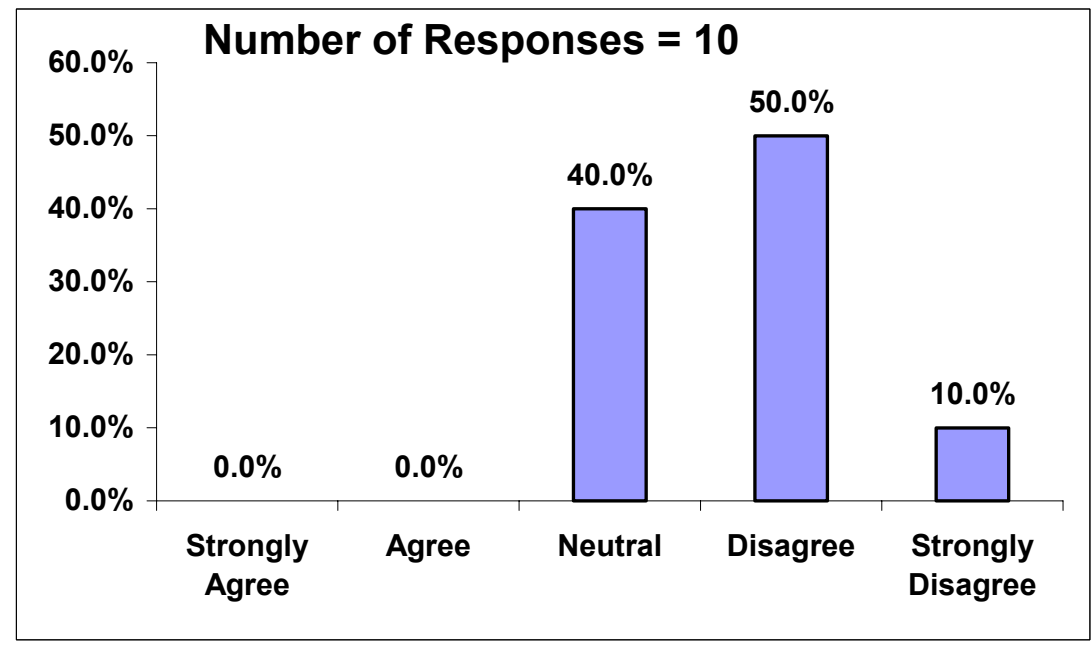

Figure 23. ACEC of Indiana member opinions: Are there fewer misunderstandings between parties in Design-Build?

Question 6: Are there other advantages of the Design-Build method for highway projects, in comparison to the Design-Bid-Build method that are not mentioned in Question 5?

None of the firms mentioned any additional advantages. 
Question 7: This question asked the ACEC of Indiana members to rate several disadvantages of the Design-Build process from "Strongly Agree" to "Strongly Disagree".

a. Loss of control over the design phase of the project - The subsequent design of a particular project is performed by the Design-Build team and the owner loses control of design.

Ten responses were received and a graphical representation of the results is shown in Figure 24.

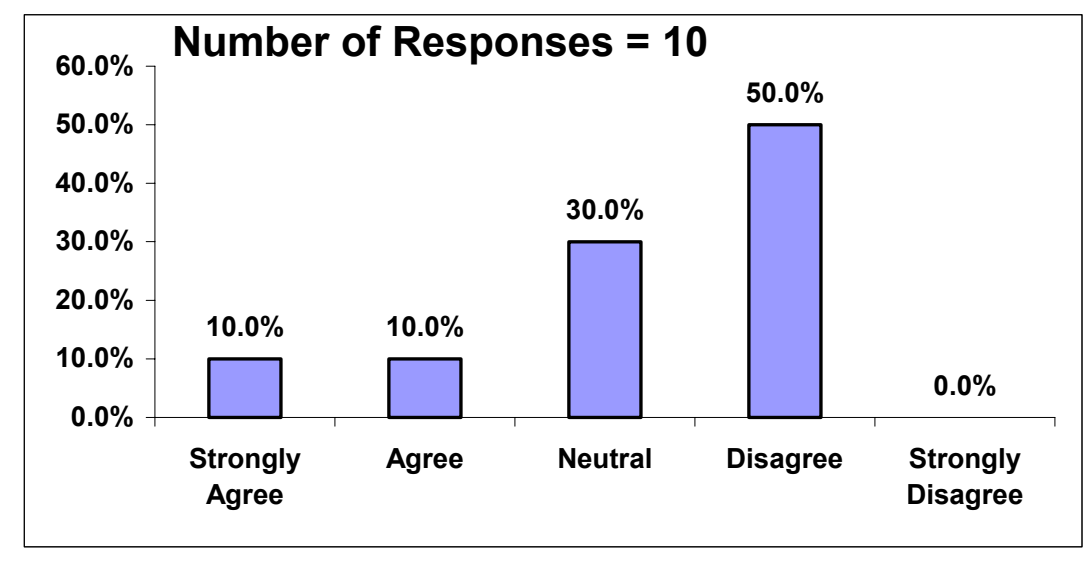

Figure 24. ACEC of Indiana member opinions: Does the owner lose control of the project's design in Design-Build?

b. It has been observed that some Design-Build firms build first and design later.

Ten responses were received and a graphical representation of the results is shown in Figure 25.

c. The owner has less input into the process and little control of the quality of the materials used in the project unless the owner has taken the time to complete a very detailed listing of materials to be used and identified other project controls that the Design-Build team is to meet.

Ten responses were received and a graphical representation of the results is shown in Figure 26. 


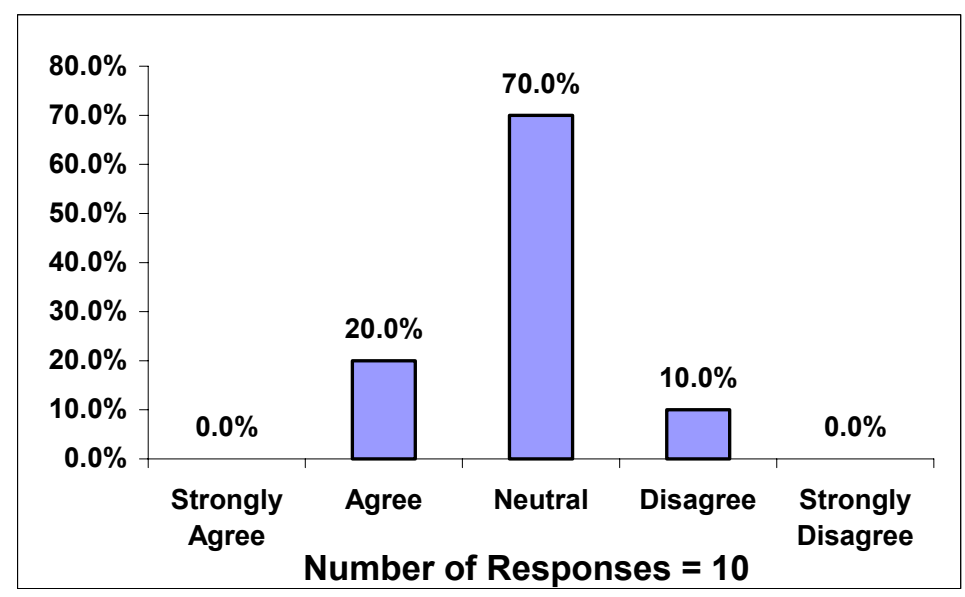

Figure 25. ACEC of Indiana member opinions: Do Design-Build teams build first and design later?

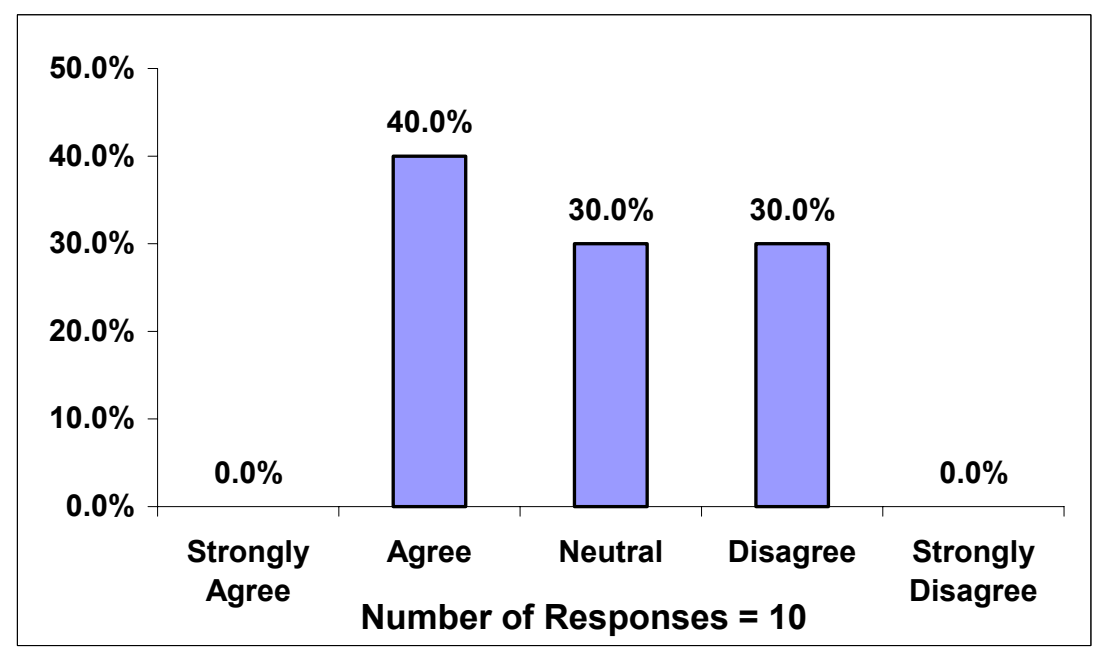

Figure 26. ACEC of Indiana member opinions: Does the owner have less control of the quality and the materials used in Design-Build?

d. The Design-Build project delivery system may be more labor intensive and technically demanding for the owner than is Design-Bid-Build. DesignBuild projects require the owner to carefully prepare a scope of work that defines its requirements in detail.

Ten responses were received, and a graphical representation of the results is shown in Figure 27. 


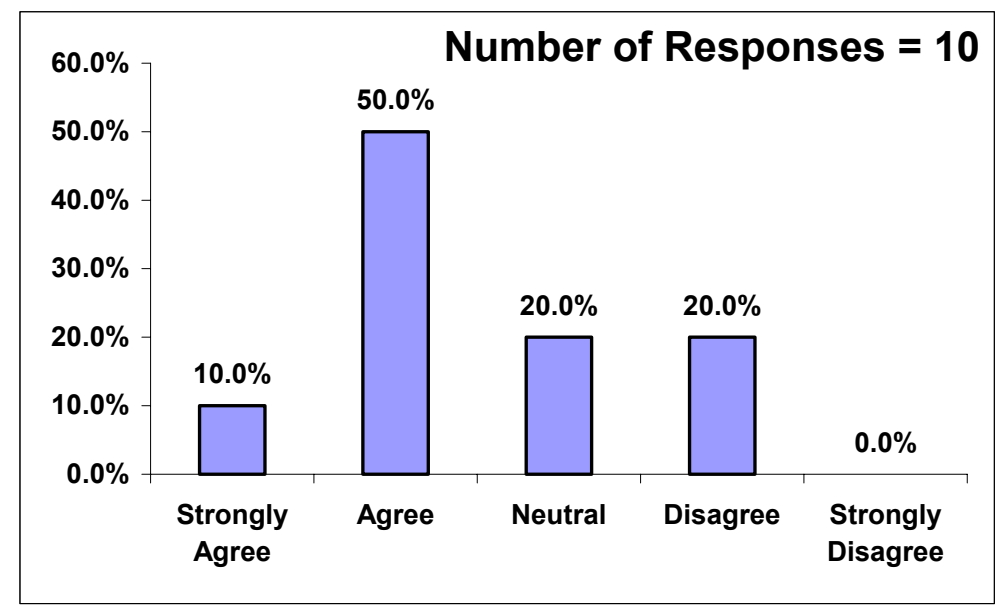

Figure 27. ACEC of Indiana member opinions: Are Design-Build projects more labor-intensive for the owner?

e. The designer may be selected on the basis of price rather than qualifications, potentially compromising the public health, safety, and welfare.

Ten responses were received and a graphical representation of the results is shown in Figure 28.

f. The Design-Build project delivery system may discourage competition. Fewer entities have the inherent capacity to provide design-build services, which larger firms are able to provide.

Ten responses were received and a graphical representation of the results is shown in Figure 29. 


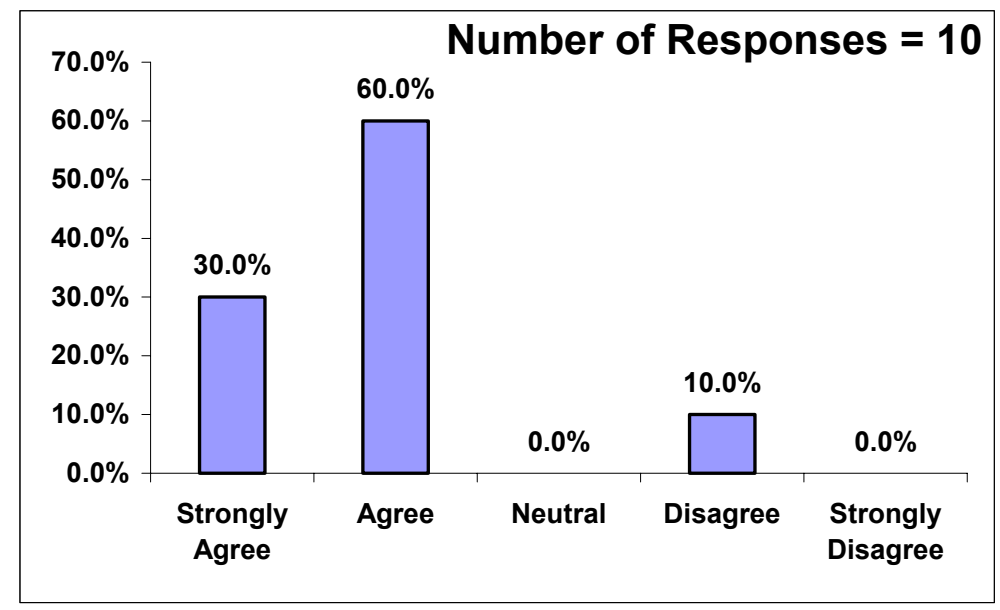

Figure 28. ACEC of Indiana member opinions: Could the Design-Build designer be chosen on the basis of price rather than qualifications?

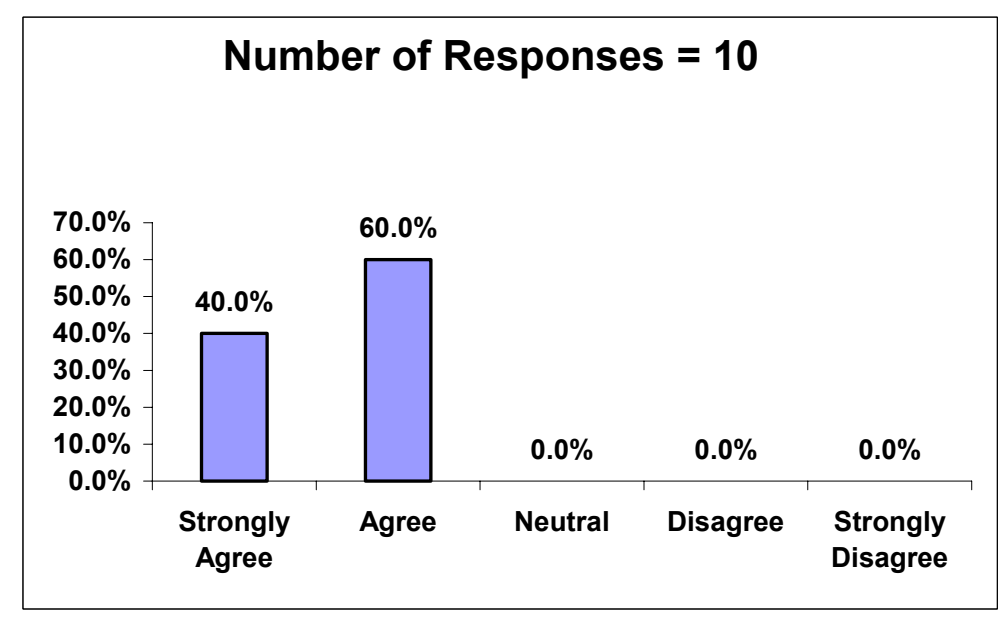

Figure 29. ACEC of Indiana member opinions: Does Design-Build limit competition?

g. The magnitude of liability risk to the designer may discourage participation by highly qualified designers.

Ten responses were received and a graphical representation of the results is shown in Figure 30. 


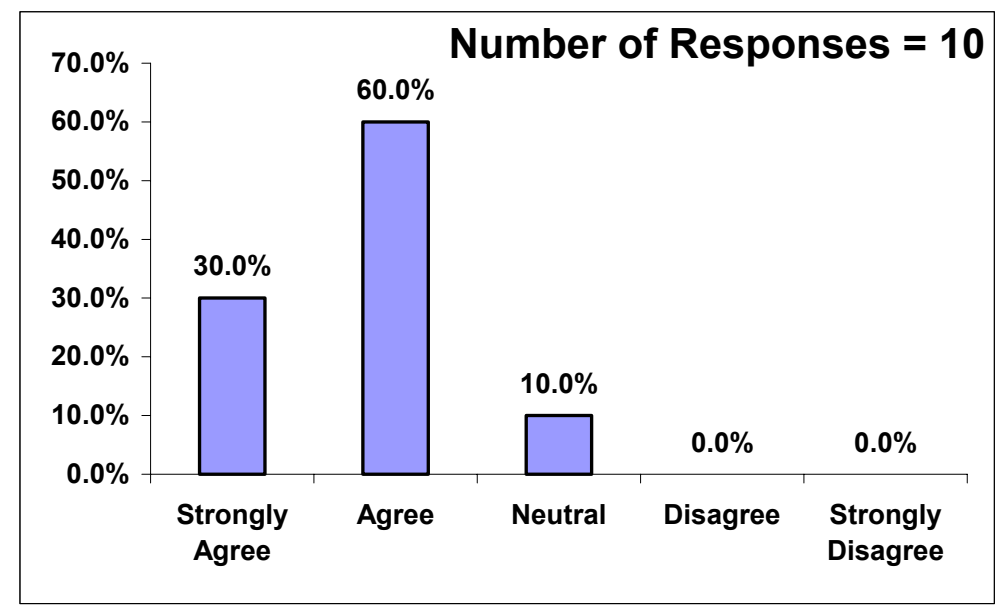

Figure 30. ACEC of Indiana member opinions: Does Design-Build discourage designers to participate due to higher risks involved?

Question 8: Are there other disadvantages of the Design-Build method for highway projects, in comparison to the Design-Bid-Build method that are not mentioned in Question 7?

All ten responses are summarized below.

- There is a tendency for design firms to concentrate all their efforts towards their Design-Build projects and putting all other work aside. That work is eventually lost if the firm is not the winning firm.

- If the designer proposes something to enhance the quality of the project, or value to the owner, the contractor typically will not approve it if it increases the cost of the project.

Question 9: Answer the following questions only if you participated in a Design-Build highway project, not necessarily in Indiana.

a. Was the scope of the project clearly defined, and what could have been done to make it better?

In part (a) the answers varied. Some designers said that the scope was well defined, while others said that there were discrepancies in the drawings they were given. 
b. Did you encounter any problems in the initial design process?

Again the answers varied. Some designers encountered no major hassle, while others claimed that there was not enough time to perform the design work and prepare a technical proposal.

c. The Design-Build method is perceived to provide innovation in construction and design. What innovation(s) occurred, if any, in the Design-Build projects you participated in?

The designers commented that little innovation was introduced mainly for constructibility issues. Any major design innovations were not approved by INDOT.

d. How far should the design be developed before it is given out for bidding? The firms that participated in the survey indicated that a good scope should provide $30 \%-40 \%$ of final design. One firm went further and suggested $100 \%$.

Question 10: Please address any items that you feel are relevant to the issue of Design-Build versus Design-Bid-Build.

All ten responses completed this item. One firm commented that the DesignBuild approach by INDOT is really a Fast Track Design method. The firm also claimed that they could operate under the same conditions and schedule in a Design-Bid-Build project, if they were given the same limited review as the current Design-Build approach.

Another firm indicated that the scope of a particular Design-Build project needs to be better defined. The better the scope the better the Design-Build proposals. Design firms would like a clearly defined scope in order to limit any uncertainties and misunderstandings.

The consulting companies expressed some concern in regards to the size of the projects performed so far. There are not many consulting companies that are willing and able to compete in the process and a major factor is the large up front costs that a design firm has to endure. 
Question 11: Would you be interested to be participating in a follow-up personal interview?

Seventy percent of the ACEC of Indiana respondents indicated they would be willing to participate in a follow-up interview.

\subsection{Summary of Responses}

A comparative summary of responses from the contractor and consultants in Indiana is presented in Table 2. Along with the general perception about Design-Build projects, the comparative summary highlights the issues that are important individually to the contractors and consultants, as well as the views with respect to the relative impacts of Design-Build projects. 


\section{Table 2}

Summary of Responses from ICI and ACEC of Indiana Survey

\begin{tabular}{|c|c|c|}
\hline & ICI & ACEC of Indiana \\
\hline $\begin{array}{l}\text { 1. Are you aware of INDOT's Design- } \\
\text { Build program? }\end{array}$ & All responses were affirmative. & All responses were affirmative. \\
\hline $\begin{array}{l}\text { 2. Did you ever consider participating in } \\
\text { any Design-Build highway project? }\end{array}$ & $\begin{array}{l}70 \% \text { of responses considered participating, } \\
30 \% \text { did not. }\end{array}$ & $\begin{array}{l}80.0 \% \text { considered participating, } 20.0 \% \text { did } \\
\text { not. }\end{array}$ \\
\hline $\begin{array}{l}\text { 3. Have you bid on an INDOT Design- } \\
\text { Build project? If 'Yes', explain any } \\
\text { problems you've had with the bidding } \\
\text { process. }\end{array}$ & $\begin{array}{l}\text { 36.7\% participated in Design-Build } \\
\text { projects, } 63.3 \% \text { did not. }\end{array}$ & $\begin{array}{l}50.0 \% \text { participated in Design-Build } \\
\text { projects, } 50.0 \% \text { did not. }\end{array}$ \\
\hline $\begin{array}{l}\text { 4. Do you think that you will be interested } \\
\text { in participating in any INDOT Design- } \\
\text { Build project in the future? If 'Yes' what } \\
\text { types of projects will you be interested in } \\
\text { participating in? If 'No', why not? }\end{array}$ & $\begin{array}{l}50.0 \% \text { are willing to participate in future } \\
\text { INDOT Design-Build projects, } 50.0 \% \text { will } \\
\text { not. }\end{array}$ & $\begin{array}{l}50.0 \% \text { are willing to participate, } 50.0 \% \text { are } \\
\text { not. }\end{array}$ \\
\hline
\end{tabular}


Table 2 cont.

\begin{tabular}{|c|c|c|}
\hline & ICI & ACEC of Indiana \\
\hline $\begin{array}{l}\text { 5. Below are advantages that have been } \\
\text { observed about the Design-Build method } \\
\text { of procurement for highway projects. Rate } \\
\text { these from "Strongly Agree" to "Strongly } \\
\text { Disagree". }\end{array}$ & & \\
\hline $\begin{array}{l}\text { 5a. Reduced Duration of Construction - } \\
\text { Design-Build decreases the overall project } \\
\text { completion time as compared to Design- } \\
\text { Bid-Build since design and construction } \\
\text { periods overlap, and redesign is mostly } \\
\text { eliminated. }\end{array}$ & $\begin{array}{l}16.7 \% \text { strongly agree, } 23.3 \% \text { agree, } 23.3 \% \\
\text { neutral, } 10.0 \% \text { disagree, and } 26.7 \% \\
\text { strongly disagree. }\end{array}$ & $\begin{array}{l}10.0 \% \text { strongly agree, } 10.0 \% \text { agree, } 20.0 \% \\
\text { neutral, } 30.0 \% \text { disagree, and } 30.0 \% \\
\text { strongly disagree. }\end{array}$ \\
\hline $\begin{array}{l}\text { 5b. Contractibility/Innovation - Design- } \\
\text { Build introduces construction knowledge } \\
\text { into design early in the process. }\end{array}$ & $\begin{array}{l}20.7 \% \text { strongly agree, } 17.2 \% \text { agree, } 20.7 \% \\
\text { neutral, } 13.8 \% \text { disagree, and } 27.6 \% \\
\text { strongly disagree. }\end{array}$ & $\begin{array}{l}10.0 \% \text { strongly agree, } 40.0 \% \text { agree, } 20.0 \% \\
\text { neutral, } 10.0 \% \text { disagree, and } 20.0 \% \\
\text { strongly disagree. }\end{array}$ \\
\hline
\end{tabular}


Table 2 cont.

\begin{tabular}{|c|c|c|}
\hline & ICI & ACEC of Indiana \\
\hline $\begin{array}{l}\text { 5c. Reduce Cost - Design-Build decreases } \\
\text { the overall project cost as compared to } \\
\text { Design-Bid-Build. Project costs are } \\
\text { identified far earlier, allowing for } \\
\text { budgetary concerns to be addressed early. } \\
\text { Also value engineering and } \\
\text { constructability are utilized since designer } \\
\text { and contractor work as a team. }\end{array}$ & $\begin{array}{l}6.9 \% \text { strongly agree, } 17.2 \% \text { agree, } 24.1 \% \\
\text { neutral, } 24.1 \% \text { disagree, } 10.3 \% \text { disagree } \\
\text { and } 41.1 \% \text { strongly disagree. }\end{array}$ & $\begin{array}{l}0.0 \% \text { strongly agree, } 10.0 \% \text { agree, } 30.0 \% \\
\text { neutral, } 20.0 \% \text { disagree, and } 40.0 \% \\
\text { strongly disagree. }\end{array}$ \\
\hline $\begin{array}{l}\text { 5d. Single Point Responsibility - The } \\
\text { Design-Build team has full responsibility } \\
\text { for the outcome of the project. The } \\
\text { contractor and the designer are allied and } \\
\text { work together as a team, giving the owner } \\
\text { the opportunity to focus on the scope and } \\
\text { needs definition rather than coordinating } \\
\text { the design aspect of the job with the } \\
\text { construction aspect. }\end{array}$ & $\begin{array}{l}10.0 \% \text { strongly agree, } 36.7 \% \text { agree, } 23.3 \% \\
\text { neutral, } 6.7 \% \text { disagree, and } 23.3 \% \text { strongly } \\
\text { disagree. }\end{array}$ & $\begin{array}{l}20.0 \% \text { strongly agree, } 20.0 \% \text { agree, } 30.0 \% \\
\text { neutral, } 30.0 \% \text { disagree, and } 0.0 \% \text { strongly } \\
\text { disagree. }\end{array}$ \\
\hline
\end{tabular}


Table 2 cont.

\begin{tabular}{|c|c|c|}
\hline & ICI & ACEC of Indiana \\
\hline $\begin{array}{l}\text { 5e. Continuity between Designer and } \\
\text { Constructor - In Design-Build projects, the } \\
\text { same entity has the expertise to design the } \\
\text { project and construct it. }\end{array}$ & $\begin{array}{l}13.3 \% \text { strongly agree, } 26.7 \% \text { agree, } 26.7 \% \\
\text { neutral, } 20.0 \% \text { disagree, and } 13.3 \% \\
\text { strongly disagree. }\end{array}$ & $\begin{array}{l}0.0 \% \text { strongly agree, } 60.0 \% \text { agree, } 20.0 \% \\
\text { neutral, } 20.0 \% \text { disagree, and } 0.0 \% \text { strongly } \\
\text { disagree. }\end{array}$ \\
\hline $\begin{array}{l}\text { 5f. In Design-Build there is less } \\
\text { misunderstanding between the parties } \\
\text { involved. }\end{array}$ & $\begin{array}{l}10.0 \% \text { strongly agree, } 16.7 \% \text { agree, } 23.3 \% \\
\text { neutral, } 16.7 \% \text { disagree, and } 23.3 \% \\
\text { strongly disagree. }\end{array}$ & $\begin{array}{l}0.0 \% \text { strongly agree, } 0.0 \% \text { agree, } 40 \% \\
\text { neutral, } 50.0 \% \text { disagree, and } 10.0 \% \\
\text { strongly disagree. }\end{array}$ \\
\hline $\begin{array}{l}\text { 6. Are there other advantages of the } \\
\text { Design-Build method for highway } \\
\text { projects, in comparison to the Design-Bid- } \\
\text { Build method that are not mentioned in } \\
\text { Question } 5 \text { ? }\end{array}$ & $\begin{array}{l}\text { Advantages mentioned: large jobs provide } \\
\text { best opportunities for efficiency } \\
\text { relationships between contractor and } \\
\text { designer are improved, and ideas from } \\
\text { experienced contractors expedite design } \\
\text { problem solutions. }\end{array}$ & No responses were given. \\
\hline $\begin{array}{l}\text { 7. Below are disadvantages that have been } \\
\text { observed about the Design-Build method } \\
\text { of procurement for highway projects. Rate } \\
\text { these from "Strongly Agree" to "Strongly } \\
\text { Disagree". }\end{array}$ & & \\
\hline
\end{tabular}


Table 2 cont.

\begin{tabular}{|c|c|c|}
\hline & ICI & ACEC of Indiana \\
\hline $\begin{array}{l}\text { 7a. It has been observed that Design-Build } \\
\text { restricts competition due to the elimination } \\
\text { of small and medium contractors because } \\
\text { they can not afford the risk associated with } \\
\text { the design liabilities and the extended } \\
\text { project liability inherent with Design- } \\
\text { Build. }\end{array}$ & $\begin{array}{l}70.0 \% \text { strongly agree, } 16.7 \% \text { agree, } 3.3 \% \\
\text { neutral, } 3.3 \% \text { disagree, and } 6.7 \% \text { strongly } \\
\text { disagree. }\end{array}$ & \\
\hline $\begin{array}{l}\text { 7b. The project cost may be greater } \\
\text { because of extra costs or claims incurred } \\
\text { when delays occur in the construction } \\
\text { phase due to the need to resolve permitting } \\
\text { and environmental issues or to solidify } \\
\text { owner preferences. }\end{array}$ & $\begin{array}{l}26.7 \% \text { strongly agree, } 30.0 \% \text { agree, } 33.3 \% \\
\text { neutral, } 6.7 \% \text { disagree, and } 3.3 \% \text { strongly } \\
\text { disagree. }\end{array}$ & \\
\hline $\begin{array}{l}\text { 7c. The project may require longer } \\
\text { completion time with the Design-Build } \\
\text { method, particularly if the scope of work } \\
\text { or permitting issues are unresolved. }\end{array}$ & $\begin{array}{l}23.3 \% \text { strongly agree, } 40.0 \% \text { agree, } 23.3 \% \\
\text { neutral, } 10.0 \% \text { disagree, and } 3.3 \% \text { strongly } \\
\text { disagree. }\end{array}$ & \\
\hline
\end{tabular}


Table 2 cont.

\begin{tabular}{|c|c|c|}
\hline & ICI & ACEC of Indiana \\
\hline $\begin{array}{l}\text { 7d. The magnitude of liability risk to the } \\
\text { designer may discourage participation by } \\
\text { highly qualified designers. Given the } \\
\text { relatively small percentage of the overall } \\
\text { project that his or her services represent, } \\
\text { the risk may far outweigh the potential } \\
\text { return. As a member of the design-build } \\
\text { team, the designer is linked to the } \\
\text { construction process to a greater degree } \\
\text { than under design-bid-build. }\end{array}$ & $\begin{array}{l}43.3 \% \text { strongly agree, } 33.3 \% \text { agree, } 10.0 \% \\
\text { neutral, } 10.0 \% \text { disagree, and } 3.3 \% \text { strongly } \\
\text { disagree. }\end{array}$ & $\begin{array}{l}30.0 \% \text { strongly agree, } 60.0 \% \text { agree, } 10.0 \% \\
\text { neutral, } 0.0 \% \text { disagree, and } 0.0 \% \text { strongly } \\
\text { disagree. }\end{array}$ \\
\hline $\begin{array}{l}\text { 7e. Design decisions may be determined or } \\
\text { inappropriately influenced by team } \\
\text { members other than the designer. This is } \\
\text { more likely to occur when a non-designer } \\
\text { is the lead on the design-build team. }\end{array}$ & $\begin{array}{l}20.0 \% \text { strongly agree, } 33.3 \% \text { agree, } 16.7 \% \\
\text { neutral, } 16.7 \% \text { disagree, and } 13.3 \% \\
\text { strongly disagree. }\end{array}$ & \\
\hline
\end{tabular}


Table 2 cont.

\begin{tabular}{|c|c|c|}
\hline & ICI & ACEC of Indiana \\
\hline $\begin{array}{l}\text { 7f. The designer may be selected on the } \\
\text { basis of price rather than qualifications, } \\
\text { potentially compromising the public } \\
\text { health, safety, and welfare. }\end{array}$ & $\begin{array}{l}26.7 \% \text { strongly agree, } 33.3 \% \text { agree, } 6.7 \% \\
\text { neutral, } 20.0 \% \text { disagree, and } 13.3 \% \\
\text { strongly disagree. }\end{array}$ & $\begin{array}{l}30.0 \% \text { strongly agree, } 60.0 \% \text { agree, } 0 \% \\
\text { neutral, } 10.0 \% \text { disagree, and } 0.0 \% \text { strongly } \\
\text { disagree. }\end{array}$ \\
\hline $\begin{array}{l}\text { 7g. Loss of control over the design phase } \\
\text { of the project - The subsequent design of a } \\
\text { particular project is performed by the } \\
\text { Design-Build team and the owner loses } \\
\text { control of design. }\end{array}$ & & $\begin{array}{l}10.0 \% \text { strongly agree, } 10.0 \% \text { agree, } 30.0 \% \\
\text { neutral, } 50 \% \text { disagree, and } 0.0 \% \text { strongly } \\
\text { disagree. }\end{array}$ \\
\hline $\begin{array}{l}\text { 7h. It has been observed that some design } \\
\text { - build firms tend to build first and design } \\
\text { later. }\end{array}$ & & $\begin{array}{l}0.0 \% \text { strongly agree, } 20.0 \% \text { agree, } 70.0 \% \\
\text { neutral, } 10.0 \% \text { disagree, and } 0 \% \text { strongly } \\
\text { disagree. }\end{array}$ \\
\hline
\end{tabular}


Table 2 cont.

\begin{tabular}{|c|c|c|}
\hline & ICI & ACEC of Indiana \\
\hline $\begin{array}{l}\text { 7i. The owner has less input into the } \\
\text { process and little control of the quality of } \\
\text { the materials used in the project unless the } \\
\text { owner has taken the time to complete a } \\
\text { very detailed listing of materials to be used } \\
\text { and identified other project controls that } \\
\text { the Design-Build team is to meet. }\end{array}$ & & $\begin{array}{l}0.0 \% \text { strongly agree, } 40.0 \% \text { agree, } 30.0 \% \\
\text { neutral, } 30.0 \% \text { disagree, and } 0 \% \text { strongly } \\
\text { disagree. }\end{array}$ \\
\hline $\begin{array}{l}7 \mathrm{j} \text {. The Design-Build project delivery } \\
\text { system may be more labor intensive and } \\
\text { technically demanding for the owner than } \\
\text { is Design-Bid-Build. Design-Build projects } \\
\text { require the owner to carefully prepare a } \\
\text { scope of work that defines its requirements } \\
\text { in detail. }\end{array}$ & & $\begin{array}{l}10.0 \% \text { strongly agree, } 50.0 \% \text { agree, } 20.0 \% \\
\text { neutral, } 20.0 \% \text { disagree, and } 0.0 \% \text { strongly } \\
\text { disagree. }\end{array}$ \\
\hline
\end{tabular}


Table 2 cont.

\begin{tabular}{|c|c|c|}
\hline & ICI & ACEC of Indiana \\
\hline $\begin{array}{l}\text { 7k. The Design-Build project delivery } \\
\text { system may discourage competition. Fewer } \\
\text { entities have the inherent capacity to } \\
\text { provide Design-Build services, which } \\
\text { larger firms are able to provide. }\end{array}$ & & $\begin{array}{l}40.0 \% \text { strongly agree, } 60.0 \% \text { agree, } 0.0 \% \\
\text { neutral, } 0.0 \% \text { disagree, and } 0.0 \% \text { strongly } \\
\text { disagree. }\end{array}$ \\
\hline $\begin{array}{l}\text { 8. Are there other disadvantages of the } \\
\text { Design-Build method for highway } \\
\text { projects, in comparison to the Design-Bid- } \\
\text { Build method, that are not mentioned in } \\
\text { Question } 7 \text { ? }\end{array}$ & $\begin{array}{l}\text { Disadvantages mentioned: Low stipends } \\
\text { discourage participation; there is lack of } \\
\text { willing designers to participate; a lot of } \\
\text { manpower and resources are wasted by } \\
\text { unsuccessful teams; Design-Build } \\
\text { encourages the cheapest design within the } \\
\text { scope of work; conflicts are caused } \\
\text { between main contractor and } \\
\text { subcontractors; Indiana projects are taken } \\
\text { by out-of-state firms. }\end{array}$ & $\begin{array}{l}\text { Disadvantages mentioned: There is a } \\
\text { tendency for bidding firms to place all } \\
\text { their efforts in the Design-Build project } \\
\text { and not getting the job; suggestions that } \\
\text { increase the cost of the project are not } \\
\text { accepted by contractor. }\end{array}$ \\
\hline
\end{tabular}


Table 2 cont.

\begin{tabular}{|c|c|c|}
\hline & ICI & ACEC of Indiana \\
\hline $\begin{array}{l}\text { 9. Answer the following Questions only if } \\
\text { you participated in any Design-Build } \\
\text { highway projects, not necessarily in } \\
\text { Indiana. }\end{array}$ & & \\
\hline $\begin{array}{l}\text { 9a. Did the Design-Build method } \\
\text { encourage innovation? If yes what } \\
\text { innovation was proposed? }\end{array}$ & Limited innovation was encouraged. & Little innovation was introduced. \\
\hline $\begin{array}{l}\text { 9b. How far should the design for a } \\
\text { particular project be developed before it is } \\
\text { given out for bidding? }\end{array}$ & $\begin{array}{l}\text { A good scope should provide } 30 \%-40 \% \text { of } \\
\text { design. }\end{array}$ & $\begin{array}{l}\text { Most of the firms indicated that } 30 \%-40 \% \\
\text { of the design is adequate, while one firm } \\
\text { indicated } 100 \% \text {. }\end{array}$ \\
\hline $\begin{array}{l}\text { 9c. Was the scope of the project clearly } \\
\text { defined, and what could have been done to } \\
\text { make it better? }\end{array}$ & & $\begin{array}{l}\text { Some said that the scope was well defined, } \\
\text { but others said that there were } \\
\text { discrepancies in the drawings. }\end{array}$ \\
\hline $\begin{array}{l}\text { 9d. Did you encounter any problems in the } \\
\text { initial design process? }\end{array}$ & & $\begin{array}{l}\text { Some said that there were no major } \\
\text { hassles; while others said that there was } \\
\text { not enough time to complete the technical } \\
\text { proposal. }\end{array}$ \\
\hline
\end{tabular}


Table 2 cont.

\begin{tabular}{|l|l|l|}
\hline & \multicolumn{1}{|c|}{ ICI } & \multicolumn{1}{|c|}{ ACEC of Indiana } \\
\hline $\begin{array}{l}\text { 10. Please address any other items that you } \\
\text { feel are relevant to the issue of Design- } \\
\text { Build versus Design-Bid-Build. }\end{array}$ & $\begin{array}{l}\text { Smaller firms cannot undertake the risks of } \\
\text { a Design-Build project. There are not } \\
\text { many consultants who are willing to } \\
\text { participate. Contractors want a better } \\
\text { definition of what should be included in } \\
\text { the technical proposal. }\end{array}$ & $\begin{array}{l}\text { Comments included that the INDOT } \\
\text { Design-Build process is a Fast Track } \\
\text { Design process and they could operate the } \\
\text { same way under a limited review contract. } \\
\text { and of the projects performed so far, a very } \\
\text { large number of firms are not able to } \\
\text { undertake such a high risk. }\end{array}$ \\
\hline $\begin{array}{l}\text { 11. Would you be interested to participate } \\
\text { in a follow-up personal interview? }\end{array}$ & $\begin{array}{l}76.2 \% \text { were willing to participate in a } \\
\text { follow-up interview. }\end{array}$ & $\begin{array}{l}70 \% \text { were willing to participate in a } \\
\text { follow-up interview. }\end{array}$ \\
\hline
\end{tabular}




\section{Follow-up Interviews}

To gain further understanding of the experiences and opinions of the participants in Design-Build projects in Indiana, several follow-up personal interviews were arranged. INDOT personnel as well as consultants and contractors were included in personal interviews. A total of 20 interviews were conducted, comprising six INDOT personnel, nine construction companies, and five consulting companies. Responses from personal interviews with each of the three groups are presented below.

\subsection{INDOT Personnel}

The six interviewees included both District and Central Office personnel involved in the Design-Build program. The district engineers expressed their opinions on several topics, including their views on the process, interaction with the Design-Build teams, quality of the work performed, inspection of quality, as well as their opinion on the Design-Build project as a whole.

Regarding their relationships with the Design-Build teams, responses were mixed. Some district personnel indicated having a good relationship with the Design-Build teams, while others were completely dissatisfied with them. Some of the negative comments mentioned that the contractor tended to ignore items that dealt with the public, like traffic maintenance.

On the topic of quality, again the responses were mixed. Some personnel were relatively satisfied with the quality of the project, even though the quality checks were a burden to overworked INDOT staff. When a separate consultant was hired to perform the quality checks, INDOT personnel were generally satisfied with the quality check process. One district interviewee commented that the quality of work in his sector was lacking and that was due to the fact that the contractor hired to perform the project was not from Indiana. He continued by saying that he would get better quality from Indiana contractors. Other district personnel indicated that the quality received was about the same for both Design-Build as well as current Design-Bid-Build projects. 
Some of the advantages of Design-Build the district personnel mentioned included the following. Design-Build is a good tool in emergency situations and special jobs that meet certain requirements. A lot of time is saved from conception to completion of the project, and as a result, road-user cost is reduced.

Some disadvantages mentioned by the district personnel were that completion of the plans usually ran behind schedule, even though a lot of time is saved by the electronic submittal of the plans.

INDOT personnel from the Central Office were also interviewed. They clarified some of the specifics of Design-Build and gave their opinion on the method based on their involvement in different projects.

Regarding involvement of INDOT personnel in Design-Build projects, it was felt that it was about the same in comparison to traditional Design-Bid-Build. In the future, though, it was felt that less INDOT personnel would be needed during the construction phase. In project development, fewer people are required. Signing and lighting still require the same amount of INDOT personnel involvement. It was mentioned that Design-Build had helped INDOT with shrinking manpower issues, as existing personnel in certain areas were relieved from a lot of the workload. In planning and development the workload had decreased significantly, and design personnel only checked the scoping plan. Field operations personnel had less administrative work to complete and that would likely continue to decrease in the future.

As to how much design should be done by INDOT, a $20 \%$ to $25 \%$ fraction was expressed to be satisfactory. It was also mentioned that Quality Assurance was still handled the same way as in Design-Bid-Build. Test results have not shown that the quality was lacking due to the Design-Build method. One INDOT employee stated that, as long as field control is held on the project, there should not be any difference in quality. Failures that occurred were not due to the Design-Build method. The number of change orders seemed to have been reduced, as indicated in the case studies discussed in Section 7. Specifically, two Design-Build projects were subsequently investigated and they showed overrun of 
$2.08 \%$ and $0.88 \%$. Three Design-Bid-Build projects of similar size showed overrun of $8.48 \%, 20.05 \%$, and $2.25 \%$, respectively.

In reviewing the technical proposals, it was pointed out that contractor innovation was not considered in awarding the project. INDOT is expecting the different Design-Build teams to understand the scope of the project and design according to that scope only. Because INDOT accepts the lowest bidder, it cannot consider innovation as a factor in the Design-Build decision.

INDOT is usually given two weeks to review the proposals, and according to the personnel involved, this is enough time for the task. Also, the technical review committee did not receive any pressure from the consultants and contractors bidding for the different projects.

Some advantages of Design-Build were brought up during the interviews. One INDOT staff member commented that Design-Build is a good alternative when there is a time constraint for completing a project. During the past few years INDOT has had a very heavy construction load and several Design-Build projects have helped to meet the construction schedule. Another advantage for INDOT is the fact that it reduces the personnel required for construction and design operations.

Some disadvantages mentioned include the fact that INDOT loses some control in tracking quantities. Also, there are not enough personnel to handle the signing and lighting operations. It was also mentioned that traffic maintenance is often sacrificed to minimize construction time. In addition, some INDOT personnel requested that the pre-design time be increased.

\subsection{Contractor and Subcontractor Members of ICI}

The ICI members who expressed willingness to participate in follow up interviews were contacted and nine interviews were conducted. The interviewees included both successful and unsuccessful contractors. Their responses concerning several topics and issues are summarized below. For confidentiality 
reasons, the names of the participants and transcripts of their interviews are not disclosed.

One major aspect of Design-Build that concerns contractors is the increased risk. The contractors believe the owner is better prepared to face these risks, but they lack the experience and capital to handle them. This is more evident for smaller companies that lack the financial ability to invest in the preparation of the technical proposal. The stipend that is given to the unsuccessful firms is not enough to cover the expenses of the companies to a satisfactory percentage. All the companies expressed the opinion that the stipend should be increased.

Another problem that ICI members mentioned is that the Design-Build method encourages secrecy and mistrust among the contractors, subcontractors, and suppliers. The contractors expressed that during the preparation of the technical proposal, they would only get in touch with a few trusted subcontractors and suppliers who would not reveal any information to their competitors. The subcontractors expressed concerns that they do not get enough information from the main contractors for them to complete their proposal accurately. They also said that they usually could not estimate true quantities and prices and run the risk of accelerated costs. This is more evident when the subcontractor's responsibilities are early in the project. The uncertainties do not allow a particular subcontractor to truly estimate the expected work and, as a result, additional work comes into play that was not previously considered. Contractors that have responsibilities later in the project are generally satisfied with the process as a whole and would like to participate in more Design-Build projects.

In regards to project quality, the ICI members expressed the opinion that with Design-Build there is a possibility of diminished quality in order to control costs. This has also been experienced in the private sector, as some companies mentioned. Some of the quality issues could be solved by a better scope, but they indicated that the quality of the project should be considered during the award of the project to the successful technical proposal.

When asked about the relationship the contractors had with the consultants they teamed with, some companies expressed concern because they had difficulty 
finding consultants willing to participate in Design-Build projects. The ICI members expressed that consultants and contractors benefited from working together in the preparation of the proposal and later on during the construction of the project.

The technical proposal preparation time was also a concern for ICI members. Some claimed that INDOT made changes in the scope during the proposal preparation time, and this hindered their ability to develop a quality proposal. Also, some of the companies were forced to dedicate most of their staff in the preparation of the Design-Build proposal, which impacted progress on other projects. They also claimed that they did not have enough time to review the proposal, and INDOT did not supply proper resources needed during the proposal preparation.

In response to the question of how much design should be performed by INDOT before it is given to the consultants for bidding, the ICI members recommended that a minimum amount of design be performed. They indicated that there should be enough design and description to define the scope of the project.

Innovation in design was something that ICI members claimed is non-existent with the current policy employed by INDOT. They claimed that all their innovations were rejected by INDOT during the initial technical proposal submission. The ICI members said that INDOT would only consider innovations that were within the specified scope of the project, and they could only be submitted after the project was awarded to them. If innovation is not used in the technical evaluation, then it should be removed as a requirement in proposal submission. ICI members that participated in Design-Build projects for the private sector indicated that the owner generally accepted their innovative design ideas.

On the topic of project size, the interviewed members of ICI mentioned that smaller jobs would increase competition. To date most of the Design-Build jobs have had only a couple of bidders.

ICI members were under the impression that the unsuccessful bidders lose every right to their technical proposal if they accept the stipend. They also 
believed that the successful bidder has the right to see the proposals of the unsuccessful bidders and use their ideas. After talking to INDOT personnel, it was discovered that the successful bidder does not see the proposals of the unsuccessful bidders.

When asked what types of contracts are appropriate to be performed with the Design-Build method of procurement, ICI indicated that Design-Build should be used in emergency situations as a "Quick Fix" tool. A considerable number of ICI members believe the current Design-Build method does not fit in the public bidding arena.

Regarding their participation in Design-Build projects in the future, some of the contractors indicated that if the current pre-proposal submission documents process is continued, they would be less likely to participate. The main reason for their lack of interest is due to the high initial costs for developing the proposal. Others commented that they might consider participating if the project sizes are reduced.

\subsection{Consultant Members of ACEC of Indiana}

When the questionnaires were received, ACEC of Indiana members who were willing to participate in follow-up interviews were contacted. Successful as well as unsuccessful consultants were contacted. Their responses concerning several topics and issues are summarized below. Again, for confidentiality reasons the names of the participants and transcripts of their phone interviews cannot be disclosed.

The ACEC of Indiana members that were interviewed expressed their opinions and concerns. One problem that all ACEC of Indiana members mentioned was the fact that during the preparation of the technical proposal, they were pressed for time. It required a great deal of effort from them, and some consulting companies found that participation in a Design-Build project restricted their personnel from performing any other work at the same time. Also, the 
changes that were made in the scope during the preparation of the technical proposals hindered their ability to perform their best work.

Another concern is the increased risk that is present in Design-Build. Errors in construction tend to revert back to the consultant, which increases the need to redesign portions of the project. Another risk is the resources required to develop the proposal, which are not recoverable in unsuccessful bids. Stipend amounts cover only a small portion of these costs.

Some consultants also pointed out that confidentiality is a big issue when it comes to Design-Build. Both the contractors and the designers are hesitant to share ideas because they do not know where they will be circulated.

In their relationship with contractors, some ACEC of Indiana members stated that it was a learning experience because they were exposed to constructability issues that normally they would not get involved with in a traditional Design-BidBuild project. The consulting teams felt that they were at times under pressure by the contractors. As a result, construction would sometimes proceed without being checked, thus increasing the chance for errors. This can be improved by awarding the contract before the construction season and before the contractor is able to start the fieldwork. The consultant would then have enough time to perform a significant portion of the design before the contractor is ready to perform any work at the construction site.

In regards to the quality of the work performed in comparison to Design-BidBuild, some of the consultants commented that a lower level of quality existed at times, but the finished construction process does not suffer.

In the question regarding which projects are better suited for Design-Build, the consultants replied that all projects are suited for Design-Build, but smaller projects might be better for smaller firms, which would ultimately attract more competition. All the firms, however, do not share this opinion. A member of ACEC of Indiana indicated that projects that are more than $\$ 50$ million are better suited for Design-Build and smaller jobs are too costly up front to be done with this method of procurement. 
ACEC of Indiana members also pointed out some advantages that are present in the Design-Build method. They commented the projects can be opened to the public faster, thus reducing lane closure time and public inconvenience.

When asked if they would participate in a future Design-Build project, the ACEC of Indiana members commented that they would weigh the risks and then decide if they would like to participate.

\section{Summary}

After analyzing the questionnaires and the follow-up interviews, the following can be deduced concerning the Design-Build method.

Many people involved in the construction industry in Indiana are not aware of all the aspects of the Design-Build method used by INDOT. Some of the contractors and subcontractors do not know the details of the method and the requirements and policies of the process; and, as a result, they do not know how to handle the price that is required for the Design-Build method. To clear up these misconceptions and misunderstandings, it is recommended that Question and Answer sessions be held to explain the program. Similar Q\&A sessions have been done by other states. These have proved to be very informative to both the contracting public and to the state DOTs.

An item that both contractors and consultants suggest is that quality should be a factor in the selection and payment process. This would put at ease some of the INDOT personnel and those concerned with issues of quality.

The consultants also indicated that the awarding of the contract should be done in late November. This would allow the consultant to perform a significant portion of the design and have enough time for its review before the contractor is able to start construction. With the current method, the consultants are rushed to finish the necessary design.

Another item that both consultants and contractors suggest is to reduce the paperwork required in the technical proposal. This would provide more time to prepare a proposal, require fewer resources, and encourage more participation. 
In addition, some smaller projects should be built with the Design-Build method in order to encourage smaller contractors to participate. Smaller projects will not likely attract larger contractors and encourage more contractors to submit a technical proposal. Small Design-Build projects have been constructed in other states in the $\$ 250,000$ range.

ICI produced a formal response to the draft final report. It raises several concerns about this report. This response is included in Appendix D

Finally, an important item that came out of the personal interviews is that INDOT should develop an informational session to train its own staff on the Design-Build method and include personnel from previous Design-Build projects to conduct this session.

\section{Case Studies}

Data for several completed Design-Build and Design-Bid-Build projects were collected and summarized in Table 3. Specifically, the data included the following five projects:

\section{$\underline{\text { Design-Build }}$}

1. R-24330 (I-65 replacement, 0.2 miles north of U.S. 30 to 0.3 miles north of $61^{\text {st }}$ street, Lake County)

2. R-25035 (I-65 replacement, 0.3 miles north of $61^{\text {st }}$ street, to I-80, Lake County)

\section{$\underline{\text { Design-Bid-Build }}$}

3. R-22177 (I-65 Rehabilitation from $29^{\text {th }}$ Street to 2.5 miles south of Lafayette Road in Marion County)

4. R-24725 (I-465 replacement from Pendelton Pike to $56^{\text {th }}$ Street in Marion County)

5. R-23901 (I-465 interchange replacement of Emerson Ave. in Marion County).

Projects 1 through 4 are interstate rehabs, and Project 5 is an interchange replacement. Project 3 is approximately three years ahead of the others in time, so it may not be appropriate for comparison. The closest comparison can be made 
between Projects 1 and 4 and Projects 2 and 4. Figure 31 shows the locations of these projects.

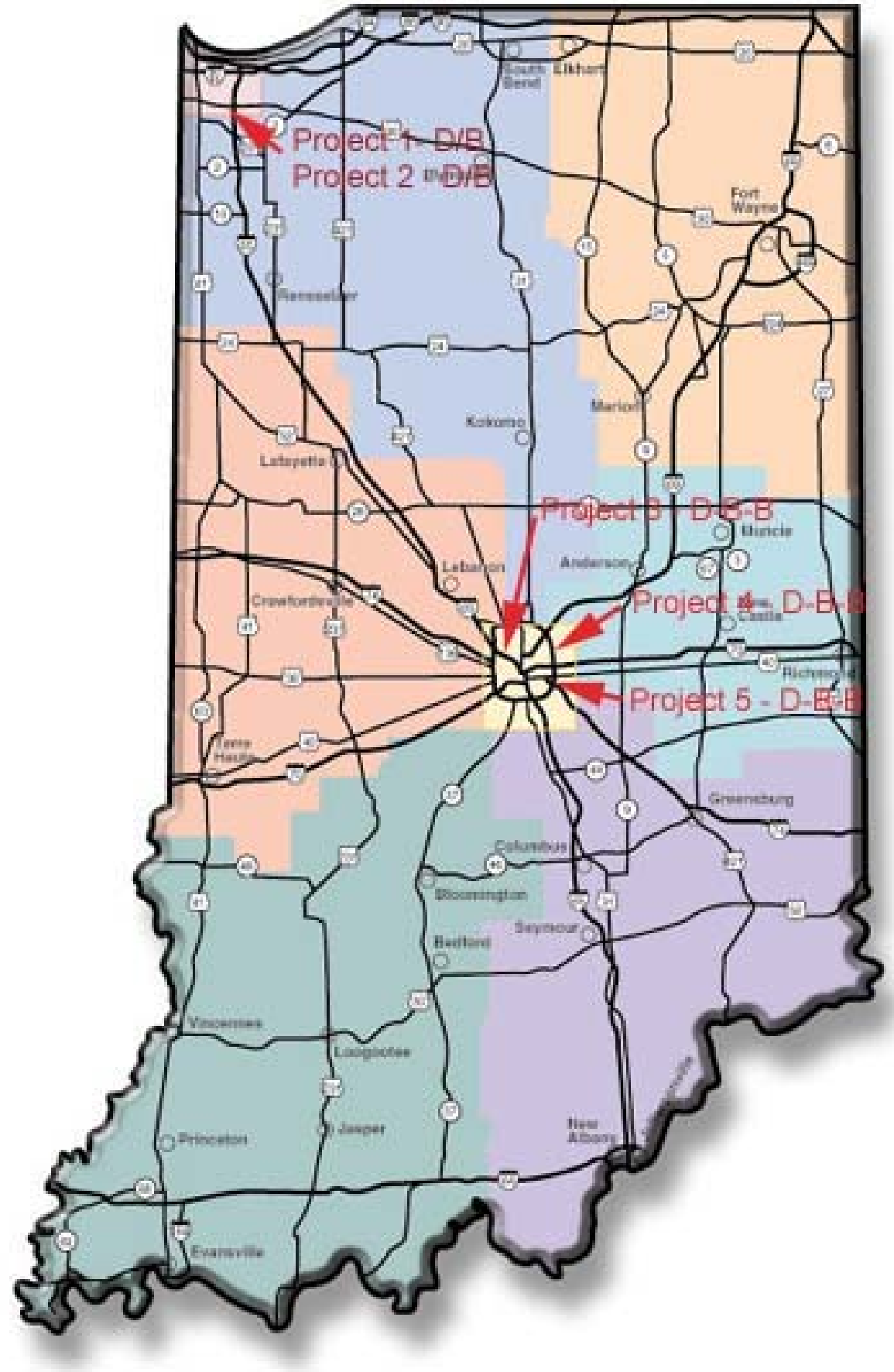

Figure 31. Project Locations

A word of caution is necessary about this comparison. Due to the limited number of Design-Build projects conducted so far, it is difficult to make firm comparative 
conclusions. Furthermore, there are many factors involved in the performance of individual projects and for a precise comparison these factors need to be considered. However, the initial data does support some of the general results found by other states as stated in this report.

Looking at Table 3, the final construction cost for Projects 1 and 2 are similar. Their construction times were 403 days for Project 1 and 570 days for Project 2, while their design times were 116 days and 158 days respectively. Comparing the final costs to the original construction estimates, Project 1 had an estimate of $\$ 31,821,929.59$ and a final construction cost of $\$ 32,482,617.28$ giving an overrun of $2.08 \%$. Project 2 had an original construction cost of $\$ 31,322,000.00$ and a final construction cost of $\$ 31,597,937,05$ giving an overrun of $0.88 \%$. The average cost overrun was $1.48 \%$ for these two Design-Build projects.

The Design-Bid-Build jobs that had construction costs in the same range, about $\$ 30$ million, had construction times of 503 days for Project 4 and 586 days for Project 5. Project 3 had a construction cost of $\$ 18,136,927,00$ and a construction time of 283 days. Project 4's scope is similar to 1 and 2, and the construction time falls between 1 and 2. A comparison of the construction times is difficult to do with the limited information. Construction time can be affected by traffic maintenance requirements, number of change orders, DBE participation, failed materials based on acceptance test results, and many other factors.

$\underline{\text { Table } 3 \text { Summary of Data Collected from Design-Build and Design-Bid-Build }}$ INDOT Projects

\begin{tabular}{|l|c|c|c|c|c|}
\cline { 2 - 6 } \multicolumn{1}{c|}{} & \multicolumn{2}{c|}{ Design-Build Projects } & \multicolumn{3}{c|}{ Design-Bid-Build Projects } \\
\cline { 2 - 6 } \multicolumn{1}{c|}{} & $\begin{array}{c}\text { R 24330 } \\
\mathbf{( 1 )}\end{array}$ & $\begin{array}{c}\text { R 25035 } \\
\mathbf{( 2 )}\end{array}$ & $\begin{array}{c}\text { R 22177 } \\
\mathbf{( 3 )}\end{array}$ & $\begin{array}{c}\text { R 24725 } \\
\text { (4) }\end{array}$ & $\begin{array}{c}\text { R 23901 (A+B) } \\
\text { (5) }\end{array}$ \\
\hline Begin Design & $04 / 01 / 99$ & $04 / 01 / 00$ & $10 / 21 / 94$ & $12 / 4 / 97$ & $10 / 18 / 95$ \\
\hline Design Finish/letting & $07 / 25 / 99$ & $09 / 05 / 00$ & $11 / 21 / 95$ & $1 / 19 / 00$ & $2 / 9 / 99$ \\
\hline Tot. Des. Time App. (days) & 116 & 158 & 396 & 776 & 1210 \\
\hline Start Construction & $10 / 25 / 99$ & $12 / 05 / 00$ & $1 / 12 / 96$ & $2 / 14 / 00$ & $3 / 16 / 99$ \\
\hline Constr. Completion & $12 / 01 / 00$ & $11 / 26 / 01$ & $10 / 21 / 96$ & $7 / 11 / 01$ & $11 / 2 / 00$ \\
\hline Tot. Constr. Time (days) & 403 & 570 & 283 & 503 & 586 \\
\hline
\end{tabular}




\begin{tabular}{|l|c|c|c|c|c|}
\hline Design \& Constr. Time & 519 & 728 & 679 & 1279 & 1796 \\
\hline Design Cost & $\$ 500,589$ & $\$ 304,298$ & $\$ 385,660$ & $\$ 1,755,400$ & $\$ 1,380,000$ \\
\hline Orig. Constr. Est. & $\$ 31,821,929$ & $\$ 31,322,000$ & $\$ 16,331,228$ & $\$ 31,499,804$ & $\$ 28,543,274$ \\
\hline Final Constr. Cost & $\$ 32,482,617$ & $\$ 31,597,937$ & $\$ 18,136,927$ & $\$ 39,016,405$ & $\$ 30,060,126$ \\
\hline Bonus & & & $\$ 420,000$ & $\$ 1,200,000$ & $\$ 875,000$ \\
\hline Des. \& Final Constr. costs & $\$ 32,983,206$ & $\$ 31,902,235$ & $\$ 18,102,587$ & $\$ 39,571,805$ & $\$ 30,565,126$ \\
\hline Overrun & $\$ 660,687$ & $\$ 275,937$ & $\$ 1,385,699$ & $\$ 6,316,601$ & $\$ 641,852$ \\
\hline Overrun (\%) & $2.08 \%$ & $0.88 \%$ & $8.48 \%$ & $20.05 \%$ & $2.25 \%$ \\
\hline
\end{tabular}

Design time, on the other hand, can be shown to be greatly reduced by DesignBuild. Specifically, Project 4 took 776 days to design and Project 5 took 1,210 days while Project 3 took 396 days. The design time of Project 4 is approximately 5-6 times longer than the design time of the Design-Build Projects 1 and 2. All three projects are interstate rehabs, so the scope of work should be similar. The comparison of the design times suggests that the Design-Build method brings projects on-line quicker to the public since the design time of the project overlaps its construction time.

Comparing the final costs to the original construction estimates, Project 3 had an estimate of $\$ 16,331,228$ and a final construction cost of $\$ 18,136,927$ giving an overrun of $8.48 \%$. Project 4 had an original construction cost of $\$ 31,499,804$ and a final construction cost of $\$ 39,016,405$ giving an overrun of $20.05 \%$. Project 5 had an original construction cost of $\$ 28,543,274$ and a final construction cost of $\$ 30,060,126$ giving an overrun of $2.25 \%$. The average overrun for the Design-Bid-Build projects is $10.26 \%$. Compared to the Design-Build average of $1.48 \%$, this figure suggests there are fewer changes and claims with the Design-Build method. This comparison should not be considered conclusive since only a few Design-Build projects are available. However, the INDOT average for Design-Bid-Build projects has typically been greater than $5 \%$.

The design costs of the projects were also obtained. Specifically, the DesignBuild projects ( 1 and 2) had a design cost of $\$ 500,589$ and $\$ 304,298$ respectively. The Design-Bid-Build projects (3, 4 and 5) had design costs of $\$ 385,660, \$ 1,755,400$ 
and $\$ 1,380,000$ respectively. The overall design and construction costs for the projects were as follows: $\$ 32,482,617$ for Project 1; $\$ 31,597,937$ for Project 2;

$\$ 18,136,927$ for Project 3; \$39,136,405 for Project 4; and \$30,060,126 for Project 5. As it can be observed, the two Design-Build projects and the Design-Bid-Build Project 4 have similar costs and a similar scope. The total design and construction time is 519 days for Project 1, 728 days for Project 2, and 1279 for Project 4. This preliminary data analysis suggests that with the Design-Build method, a considerable amount of time can be saved primarily because of shortened design time. 


\section{Conclusions}

The survey and follow-up interviews revealed a widespread resistance to the INDOT Design-Build program. The reasons given include the following: 1) projects are too large resulting in only a few contractors being able to participate; 2) the concept of the consultant working for the contractor is a new one; 3) starting construction before design is complete has caused anxiety and problems with designers and subcontractors; 4) the cost to develop a proposal is considerably higher than that for a traditional Design-Bid-Build contract and the stipend provided covers a small portion of this expense; 5) the reduced design time increases the chance of design errors and creates the perception of lowering quality; 6) the proposal development process reduces competition among subcontractors because alliances are formed that result in fewer subcontractors bidding; and 7) due to the uncertainty of the plans and the increased risk assumed by the contractor, higher subcontractor prices have been reported.

The program has lost some credibility within the contracting community because of the bidding history. For example, on three projects the engineer's estimate was $\$ 40 \mathrm{M}, \$ 75 \mathrm{M}$, and $\$ 90 \mathrm{M}$, and the corresponding bids were $\$ 30 \mathrm{M}, \$ 98 \mathrm{M}$, and $\$ 70 \mathrm{M}$, respectively. These amounts vary significantly, casting doubt and skepticism among the contractors from the very outset on the engineer's estimate in particular and the entire Design-Build process in general.

Another concern with the initial projects is the lack of bidders. The first five (5) Design-Build jobs had an average of two bidders, while other projects had at least five bidders and in most cases more. Lack of competition is not good for INDOT and the state of Indiana and increases the possibility of not getting the best price. However, one reason for the lack of bidders might have been the size of the initial projects which were very large and possibly eliminated a considerable number of Indiana contractors from participating. Smaller contracts should improve this situation.

It should be noted that Design-Build is a relatively new contract delivery process for Indiana and experience is limited. Consequently, while some of the resistance is 
justifiable, much of it can be attributed to the fact that the unknown creates uncertainty and fosters reluctance to change. The Design-Build process has been successful with other organizations, both private and public. Its benefits are: 1) a shorter time to bring the project on-line by reducing design time; 2) improved cooperation and sharing between the designer and the contractor, which in turn creates a more effective effort; 3 ) less uncertainty in final construction costs; and 4) reduced supervisory needs from the DOT. For these reasons, the continued use of Design-Build by INDOT can be supported. To improve the acceptance and use of this method the following recommendations are being made.

1. The Design-Build program needs to use smaller projects because the larger projects have excluded many Indiana contractors due to the financial risks that are involved with large projects. Even though several states, like Arizona, have only experimented with large-scale projects and have been quite satisfied with their performance, smaller projects will be more appealing to the majority of Indiana contractors. States like Ohio and Florida have used Design-Build for projects that range from a million to several hundred million dollars. Experiences from these states indicate that Design-Build can be a successful approach regardless of the job size.

2. Because Design-Build is a fast paced method of project delivery, it is desirable to have a large part of the design ready before the contractor starts any site work. To achieve this, the Design-Build projects should be awarded during late fall so that during the dead construction period in winter, the consultant can prepare a substantial amount of the design, thus eliminating possible errors that might arise due to rushing to completion and lack of proper plan review. This will also help subcontractors involved in the early activities. Also, only projects that are free of utility problems should be considered for Design-Build. As utility problems are often not discovered until the construction phase of a project, INDOT should consider the appropriateness of requiring Subsurface Utility Engineering (SUE) in the design phase of all construction projects, regardless of the project delivery method used. 
3. There is a need to evaluate the level of design required of INDOT and its consultants before letting. While it is recognized that there are many factors that can affect the pre-contract design level, the information from other states indicates that for signals and lighting projects, most of the DOTs perform a large portion of the design, which sometimes can reach $80 \%$ to $90 \%$, and for roads and bridges, most of the agencies perform $15 \%$ to $25 \%$ of the design. It will be useful to identify the factors that are important in the detailed scope depending on the project type.

4. Requirements for the submission of the technical proposal need to be evaluated in order to minimize costs and maximize the participation of consulting firms. The costs associated with the preparation of technical proposals are often so large that many firms shy away from participating. A concern that was mentioned by the consultants and the contractors alike is that the stipend that is given to the unsuccessful bidders is too low and covered only approximately $20 \%$ of their costs. Depending on the project, INDOT should consider either increasing the stipend amount or reducing the submittal requirements. For instance, if innovation is not used in selecting a contractor, then this requirement should be removed. Also, it is necessary to state clearly how innovation would be evaluated and what level of innovation INDOT would be willing to accept. On the other hand, if cost alone is the only selection criterion, then all other submittal requirements need to be evaluated for elimination. If proposal requirements were closer to those expected for a traditional Design-Bid-Build contract, more firms would be interested and participate in the program.

5. A number of participating firms indicated that there were changes made in the scope during the technical proposal development, hindering some firms from completing their necessary documents in time. It has been suggested that time extensions be granted with any change in scope. Also, both contractors and consultants recommended improving the description of the scope of work they receive. 
6. INDOT should evaluate the personnel needed to adequately supervise DesignBuild as well as other projects that are on accelerated pace. Some DesignBuild projects have used a 24-hour schedule, which has created problems for INDOT supervisory personnel and quality concerns.

7. A critical concern among contractors regarding Design-Build projects is the lack of clarity about the risks assumed by a contractor. In order to encourage increased participation of contractors and consultants in Indiana in the DesignBuild process, information sessions need to be organized so that the risks and measures to address them can be clearly understood. Similar sessions have been used in other states in order to eliminate concerns and worries that prospective participants might have and to explain the program procedures. At the same time, INDOT should have a continual training process to inform its personnel of their responsibilities. INDOT personnel from the districts, as well as from the Central Office, should meet to share concerns and experiences from Design-Build projects and gain knowledge and insight from each project. It would be beneficial to develop a correspondence/communication flowchart. This can effectively eliminate misunderstandings that might occur due to miscommunications between project participants. Also, it would be beneficial to develop project management guidelines.

The case studies examined, although limited, showed that in Design-Build projects the construction time is comparable to that of Design-Bid-Build projects. Design time, though, is greatly reduced in Design-Build projects since it overlaps the construction period. In the five projects analyzed (two Design-Build and three Design-Bid-Build), there were fewer cost overruns with the Design-Build projects, indicating that in Design-Build projects there were fewer claims at the end of the construction, and as a result the estimated cost of the project did not change by a large amount compared to the Design-Bid-Build projects.

The initial set of Design-Build projects has shown sufficient promise as a project delivery method. The first few projects completed have provided experiences that are invaluable in the understanding of the process. In general, there is enthusiasm about the program by those who have been involved. For example, the following comments 
were received at a follow-up partnering workshop conducted at the completion of one of the Design-Build projects by INDOT:

- “... due to the Design-Build innovations the contractor came up with, it saved the state of Indiana \$4 million on bid day” (Contractor).

- "The quality achieved exceeded all the specifications" (INDOT Representative).

- "The Design-Build process saved about two-three years in getting the project completed, which drives the user cost down substantially because the road is opened earlier" (INDOT Representative and Contractor).

Questions and doubts still exist, but results from projects completed and with information from other state DOTs, it is obvious that there is a place for Design-Build in INDOT when the right conditions exist. When a shortened project delivery time is needed, deadlines are demanding, or an emergency situation arises, Design-Build can be a preferred method. As INDOT undertakes more Design-Build projects, it is recommended that it monitor the performance of such projects by conducting appropriate ex post facto evaluation and in-depth case studies. The accumulated experience can then help in continued improvement of this important contract delivery process. 


\section{$\underline{\text { References }}$}

1. A.D. Songer and K.R. Molenaar, "Selecting Design-Build: Public and Private Sector Owner Attitudes," University of Colorado Design-Build Research Papers, 2001, www.colorado.edu.

2. A.W. Pickard-Cambridge, The Theater of Dionysus in Athens, Oxford, The Clarendon Press, 1946.

3. K.H. Natkin, "Legal Aspects of Design/Build", The American Institute of Architects Journal, 83(9), 125-127.

4. Federal Highway Administration, Webpage on Design-Build, 2001, www.fhwa.dot.gov.

5. Jeffery W. Brown, Alabama Department of Transportation (ALDOT), R\&D Engineer, Private Correspondence, 2001.

6. Ron Williams, Arizona Department of Transportation (ADOT), Assistant State Engineer, Private Correspondence, 2001.

7. ADOT Construction Group, "Design-Build Procurement and Administration Guide", 2 ${ }^{\text {nd }}$ Ed., 2001.

8. Tim Graggs, California Department of Transportation (Caltrans), "Value Engineering," 2001.

9. A. Ardani and P. Jesaitis, "Evaluation of Design-Build Practice in Colorado IR (CX) 70-4(143)", CDOT, July 1999.

10. P. Graham, "Evaluation of Design-Build Practice in Colorado IR IM(CX) 0253(113)", CDOT, March 2001.

11. Brian Blancherd, Florida Department of Transportation (FDOT), State Roadway Design Engineer, Private Correspondence, 2001.

12. Elisa Choplin, Maryland Department of Transportation (MDOT), Private Correspondence, 2001.

13. Ken Sweeny, Maine Department of Transportation (MDOT), Private Correspondence, 2001.

14. Maine Department of Transportation, "Final Report SEP-14 Design-Build contract for Sagadahoc Bridge,” PIN 2393.20, June 2001. 
15. Win Stebbins, Michigan Department of Transportation (MDOT), Private Correspondence, 2001.

16. Richard Jaffe, New Jersey Department of Transportation (NJDOT), "Value Engineering," 2001.

17. Steven DeWitt, North Carolina Department of Transportation (NCDOT), Private Correspondence, 2001.

18. Dan Groh, Ohio Department of Transportation (ODOT), Design-Build Engineer, Private Correspondence, 2001.

19. Ohio DOT, Webpage on Design-Build, 2001, www.dot.state.oh.us.

20. Bob Burns, Oregon Department of Transportation (ODOT), "Alternative Contracting,” 2001.

21. Rocque Kneece, South Carolina Department of Transportation (SCDOT), "Program Development," 2001.

22. Carter \& Burgess, Inc, "I-15 Corridor Reconstruction Project, Design-Build Evaluation, 1999 Annual Report, SEP 14", March 2000.

23. Jeff Carpenter, Washington Department of Transportation (WSDOT), Alternative Project Delivery Manager, Private Correspondence, 2001.

24. Walt Land, Indiana Department of Transportation (INDOT), Quality Development Manager, Private Correspondence, 2001.

25. R. W. Stidger, "Special Feature: Agencies and Contractors Working Together," Better Roads, March 2002, pp. 52-56. 


\section{Appendix A}

\section{Design-Build Practices by Different States Under Special Experimental Project 14 (SEP14) "Innovative Contracting"}

\begin{tabular}{|l|c|c|c|c|}
\hline A. State & Design-Build & $\begin{array}{c}\text { Design-Build- } \\
\text { Warrant }\end{array}$ & $\begin{array}{c}\text { Design-Build- } \\
\text { Maintain }\end{array}$ & $\begin{array}{c}\text { Design-Build- } \\
\text { Operate- } \\
\text { Maintain }\end{array}$ \\
\hline Alabama & $\mathrm{X}$ & & & \\
\hline Alaska & $\mathrm{X}$ & $\mathrm{X}$ & & $\mathrm{X}$ \\
\hline Arizona & $\mathrm{X}$ & $\mathrm{X}$ & & \\
\hline Arkansas & $\mathrm{X}$ & & & \\
\hline California & $\mathrm{X}$ & & & \\
\hline Colorado & & & & \\
\hline Connecticut & & & & \\
\hline Delaware & $\mathrm{X}$ & & & \\
\hline District of Columbia & $\mathrm{X}$ & & & \\
\hline Florida & & & & \\
\hline Georgia & $\mathrm{X}$ & & & \\
\hline Hawaii & & & & \\
\hline Idaho & $\mathrm{X}$ & & & \\
\hline Illinois & & & & \\
\hline Indiana & & & & \\
\hline Iowa & & & & \\
\hline Kansas & & $\mathrm{X}$ & & \\
\hline Kentucky & & $\mathrm{X}$ & & \\
\hline Louisiana & & & & \\
\hline Maine & & & & \\
\hline Maryland & & & & \\
\hline Massachusetts & & & & \\
\hline Michigan & & & & \\
\hline Minnesota & & & & \\
\hline Mississippi & & & & \\
\hline Missouri & & & & \\
\hline Montana & & & & \\
\hline Nebraska & & & \\
\hline Nevada & & & \\
\hline New Hampshire & & & & \\
\hline New Jersey & & & \\
\hline New Mexico & & & \\
\hline New York & & & & \\
\hline North Carolina & & & \\
\hline North Dakota & & & & \\
\hline
\end{tabular}




\begin{tabular}{|l|c|c|c|c|}
\hline \multicolumn{1}{|c|}{ State } & Design-Build & $\begin{array}{c}\text { Design-Build- } \\
\text { Warrant }\end{array}$ & $\begin{array}{c}\text { Design-Build- } \\
\text { Maintain }\end{array}$ & $\begin{array}{c}\text { Design-Build- } \\
\text { Operate- } \\
\text { Maintain }\end{array}$ \\
\hline Ohio & $\mathrm{X}$ & & & \\
\hline Oklahoma & & & & \\
\hline Oregon & $\mathrm{X}$ & & & \\
\hline Pennsylvania & $\mathrm{X}$ & & & \\
\hline Puerto Rico & & & & \\
\hline Rhode Island & & & & \\
\hline South Carolina & $\mathrm{X}$ & & & \\
\hline South Dakota & & & & \\
\hline Tennessee & & & & \\
\hline Texas & & & & \\
\hline Utah & $\mathrm{X}$ & $\mathrm{X}$ & $\mathrm{X}$ & \\
\hline Vermont & & & & \\
\hline Virginia & & & & \\
\hline Washington & $\mathrm{X}$ & & & \\
\hline West Virginia & & & & \\
\hline Wisconsin & & & & \\
\hline Wyoming & & & & \\
\hline \multicolumn{1}{l}{} & & & & \\
\hline
\end{tabular}




\section{Appendix B-1 Design-Build Questionnaire for INDOT Personnel}

Please return questionnaire in one of the following ways:
1. E-mail tymvios@purdue.edu
2. Regular Mail
3. Fax. No: (765) 496-1105
Nicholas Tymvios
School of Civil Engineering
1284 Civil Engineering Building
Purdue University
W. Lafayette IN 47906

\section{Name : \\ Title : \\ Section A \\ Initial work}

1. Which projects did you work on?

2. How long did it take INDOT to complete its initial design work, and what percentage of design INDOT and/or its consultants performed?

3. Was the scope of the project well defined? (Yes / No) Please elaborate.

4. Where there any changes made in the scope of the project after the Design-Build team won the bid?

(Yes / No) Please elaborate.

5. If 'Yes' in Question 4, please explain reasons for change.

6. Did these changes cause any friction between INDOT and Design-Build team? (Yes/No) Please elaborate. 


\section{Section B \\ Pre-bid}

1. What percentage of design do you consider necessary to be performed by INDOT and/or its consultants?

2. In the projects that you worked on, was the designed performed by INDOT and/or its consultants adequate for the bidding Design-Build teams to complete their bid? (Yes / No) Please elaborate.

3. Was there enough time for the bidding firms to complete their bid? (Yes / No) Please elaborate.

4. Do you believe that there is a higher requirement for detailed description of the design preferences in Design-Build projects compared to Design-Bid-Build projects?

(Yes/No) Please elaborate.

\section{Section C}

\section{Construction}

1. Were you satisfied by the design performed by the Design-Build teams? (Yes/No) Please elaborate.

2. Did the design performed by the Design-Build teams meet INDOT specifications? (Yes/No) Please elaborate.

3. Was there any innovation in design? (Yes / No) Please elaborate.

4. During construction did you perform any inspection and quality control on the projects?

(Yes / No) Please elaborate.

5. Were there any errors found during construction? (Yes / No) Please elaborate. 
6. If yes in Question 5, what were the causes of these errors?

7. Were there delays caused by right-of-way issues? (Yes / No) Please elaborate.

8. Was there any miscommunication between the Design-Build team and INDOT? (Yes / No) Please elaborate.

9. What could have been done to avoid these miscommunications?

10. Do you believe you had enough personnel at the site for Quality Assurance? (Yes / No) Please elaborate.

11. Do you think that it is better if the control of the quality checks fall on the DesignBuild teams? (Yes / No) Please elaborate.

12. Do you think it is good that INDOT had fewer responsibilities for inspection, testing and quality control? (Yes / No) Please elaborate.

13. Do you believe the Design-Build team had tendencies to assume that the plans were only a guideline and field changes could be made without the review of the design by their design personnel?

(Yes/No) Please elaborate.

\section{Section D}

\section{Post Construction}

1. Are you satisfied with the performance of Design-Build projects in regards to the overall quality of the projects?

(Yes / No) Please elaborate.

2. Were the projects delivered in adequate time or were there delays? (Yes / No) Please elaborate. 
3. Were these delays caused by construction or by the pre-bid design process? (Yes / No) Please elaborate.

4. In comparison to projects performed by the Design-Bid-Build method, were there more or less delays in the Design-Build projects?

(More/Less) Please elaborate.

5. Do you think the Design-Build method costs less than the Design-Bid-Build approach?

(Yes / No) Please elaborate.

6. Based on your experiences, is Design-Build a good alternative to the Design-BidBuild method?

(Yes / No) Please elaborate.

7. What are the advantages of Design-Build based on the projects you were involved?

8. What are the disadvantages of Design-Build based on the projects you were involved? 


\section{$\underline{\text { Appendix B - } 2 \text { Design-Build Questionnaire for INDOT Consultants }}$}

Please return questionnaire in one of the following ways:
1. E-mail
tymvios@purdue.edu
2. Regular Mail
3. Fax. No: (765) 496-1105
Nicholas Tymvios
School of Civil Engineering
1284 Civil Engineering Building
Purdue University
W. Lafayette IN 47906

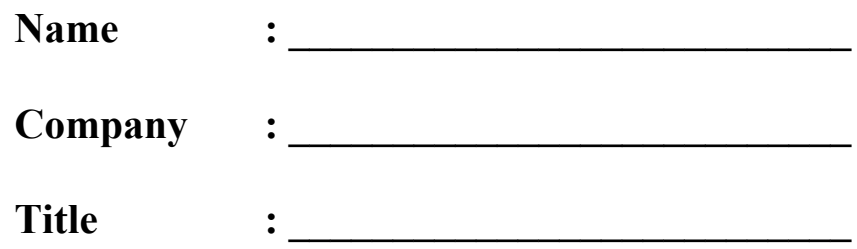

\section{Section A}

Initial work

1. Which Design-Build projects did you work on?

2. Was the scope of the project clearly explained from the beginning?

3. Were there necessary changes that needed to be made in the scope of the project? (Yes/ No) Please elaborate.

4. If there were changes made in the scope, did they cause any delays in the design process and your interaction with the Design-Build team? (Yes/ No) Please elaborate.

\section{Section B}

Pre-bid

1. Were you involved in any pre-bid design work for Design-Build projects as an INDOT consultant? (Yes/No) If 'No' proceed to Question 5.

2. In the pre-bid design work you were involved, was the design performed by you adequate for the Design-Build teams to complete their bid? 
(Yes/No) Please elaborate.

3. Was there enough time for the bidding firms to complete their bid? (Yes/No) Please elaborate.

4. Do you believe that there is a higher requirement for detailed description of the design preferences in Design-Build projects compared to Design-Bid-Build projects?

(Yes/No) please elaborate.

5. What percentage of design of a typical Design-Build project do you consider necessary to be performed by INDOT - Consultant?

\section{Section C}

\section{Construction}

1. Were you satisfied by the design performed by the Design-Build team? (Yes/No) Please elaborate.

2. Was there any problem for the design performed by the Design-Build teams to meet INDOT specifications?

(Yes/No) Please elaborate.

3. Was there any innovation in design? (Yes / No) Please elaborate.

4. During construction did you perform any inspection and quality control on the projects?

(Yes / No) Please elaborate.

5. Were there any misunderstandings between INDOT consultants and Design-Build teams?

(Yes/No) Please elaborate.

6. Were these misunderstandings caused by pre-bid design problems? (Yes / No) Please elaborate. 
7. Were there delays caused by right-of-way issues? (Yes / No) Please elaborate.

8. Was there any problem of communication between the Designer - Build team and INDOT?

(Yes / No) Please elaborate.

9. What could have been done to avoid these miscommunications?

\section{Section D \\ Post Construction}

1. Are you satisfied with the performance of the Design-Build projects in regards to the overall quality of the project?

(Yes / No) Please elaborate.

2. Were there delays caused by construction or by the pre-bid design process? (Yes / No) Please elaborate.

3. Based on your experiences is Design-Build a good alternative to the Design-BidBuild method? (Yes / No) Please elaborate.

4. What are the advantages of Design-Build based on the projects you were involved?

5. What are the disadvantages of Design-Build based on the projects you were involved? 


\section{Appendix B-3 Design-Build Questionnaire for Design-Build Teams}

Please return questionnaire in one of the following ways:
1. E-mail
2. Regular Mail
3. Fax. No: (765) 496-1105
tymvios@purdue.edu
Nicholas Tymvios
School of Civil Engineering
1284 Civil Engineering Building
Purdue University
W. Lafayette IN 47906

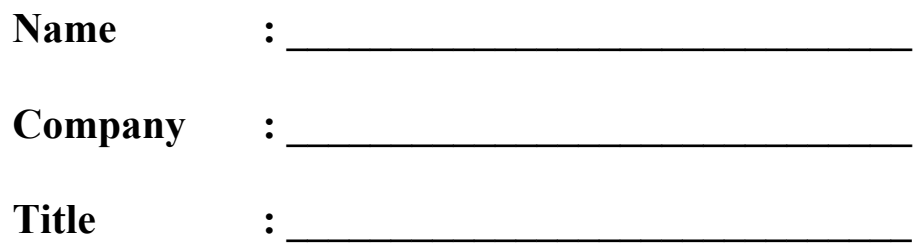

\section{Section A}

Initial work

1. Which projects did you work on?

2. What was the overall cost of the projects?

\section{Section B \\ Pre-bid}

1. Was the level of design performed by INDOT and their consultants sufficient for you to complete your bid?

(Yes/No) Please elaborate.

2. What percentage of design of a typical Design-Build project do you consider necessary to be performed by INDOT and their consultants?

3. Was there enough time for you to adequately complete the bid? (Yes/No) Please elaborate. 


\section{Section C \\ Construction - Design}

1. Was there any problem for you to complete the design, of the Design-Build project, according to INDOT's specifications?

(Yes/No) Please elaborate.

2. Did construction meet the design requirements?

(Yes/No) Please elaborate.

3. Was there any innovative design or construction method employed in the DesignBuild project you worked on?

(Yes/No) Please elaborate.

4. Was there sufficient time for you to complete design? (Yes/No) Please elaborate.

5. Were there delays in the construction caused by your part of the design process? (Yes/No) Please elaborate.

6. If you answered yes in Question 5, what were the causes of these delays?

7. How did you perform the quality control on the project, and what were the problems that were discovered during the quality checks?

8. Were there any communication problems between you and INDOT? (Yes/No) Please elaborate.

9. What could have been done to avoid these miscommunications?

10. Was there enough INDOT personnel at the site to perform Quality Assurance? (Yes/No) Please elaborate. 
11. Do you think it is better if the Design-Build team controls the quality checks for the Design-Build projects?

(Yes/No) Please elaborate.

12. Were there any design errors found during construction? (Yes/No) Please elaborate.

13. Was INDOT able to supply you with all the right of way on time? (Yes/No) Please elaborate.

14. Were all the environmental concerns dealt with by INDOT? (Yes/No) Please elaborate.

15. Was the scope of the project clearly defined? (Yes/No) Please elaborate.

16. Were there changes in the scope of the project made during construction? (Yes/No) Please elaborate.

17. Did these changes cause delays or increase in the cost of the project? (Yes/No) Please elaborate.

18. Did these changes in the scope cause any friction between you and the INDOT? (Yes/No) Please elaborate.

\section{Section D \\ Post Construction}

1. Do you think INDOT's selection process, for the successful bidder, is fair and good?

(Yes/No) Please elaborate.

2. Are you satisfied with your performance in the Design-Build projects in comparison to Design-Bid-Build projects you participated? (Yes/No) Please elaborate. 
3. Do you believe the cost of the Design-Build project would have been less if it were constructed using the Design-Bid-Build method?

(Yes/No) Please elaborate.

4. What are the advantages of Design-Build based on the projects you were involved?

5. What are the disadvantages of Design-Build based on the projects you were involved? 


\section{Appendix C - 1 Design-Build Questionnaire for Members of Indiana}

Constructors Inc.

Please return questionnaire in one of the following ways:

1. E-mail tymvios@purdue.edu
2. Regular Mail

Nicholas Tymvios

School of Civil Engineering

1284 Civil Engineering Building

Purdue University

W. Lafayette IN 47906

3. Fax. No: (765) 496-1105

Name:

Title:

Phone No.:

E-mail:

Company name:

Construction type:

(Type of construction your company is primarily working on, i.e. residential, highway, etc)

1. Are you aware of INDOT's Design-Build program? (Yes/No)

2. Did you ever consider participating in any Design-Build highway project? (Yes/No)

3. Have you bid on an INDOT Design-Build project? (Yes/No) If 'Yes', explain any problems you've had with the bidding process.

4. Do you think that you will be interested in participating in any INDOT DesignBuild project in the future?

(Yes/No). If 'Yes' what types of projects will you be interested in participating in? If 'No', why not? 
5. Below are six of the advantages that have been observed about the Design-Build method of procurement for highway projects. Rate these from "Strongly Agree" to "Strongly Disagree".

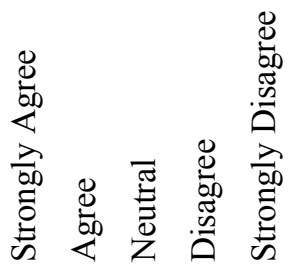

a. Reduced Duration of Construction - Design-Build decreases the overall project completion time as compared to Design-Bid-Build since design and construction periods overlap, and redesign is mostly eliminated.

b. Contractibility/Innovation - Design-Build introduces construction knowledge into design early in the process.

c. Reduce Cost - Design-Build decreases the overall project cost as compared to Design-Bid-Build. Project costs are identified far earlier, allowing for budgetary concerns to be addressed early. Also value engineering and constructability are utilized since designer and contractor work as a team.

d. Single Point Responsibility - The Design-Build team has full responsibility for the outcome of the project. The contractor and the designer are allied and work together as a team, giving the owner the opportunity to focus on the scope and needs definition rather than coordinating the design aspect of the job with the construction aspect.

e. Continuity between Designer and Constructor - In DesignBuild projects, the same entity has the expertise to design the project and construct it.

f. In Design-Build there is less misunderstanding between the parties involved

6. Are there other advantages of the Design-Build method for highway projects, in comparison to the Design-Bid-Build method that are not mentioned in Question $5 ?$ 
7. Below are six of the disadvantages that have been observed about the Design-Build method of procurement of for highway projects. Rate these from "Strongly Agree" to "Strongly Disagree".

a. It has been observed that Design-Build restricts competition due to the elimination of small and medium contractors because they can not afford the risk associated with the design liabilities and the extended project liability inherent with Design-Build.

b. The project cost may be greater because of extra costs or claims incurred when delays occur in the construction phase, due to the need to resolve permitting and environmental issues or to solidify owner preferences.

c. The project may require longer completion time with the Design-Build method, particularly if the scope of work or permitting issues are unresolved.

d. The magnitude of liability risk to the designer may discourage participation by highly qualified designers. Given the relatively small percentage of the overall project that his or her services represent, the risk may far outweigh the potential return. As a member of the design-build team, the designer is linked to the construction process to a greater degree than under design-bid-build.

e. Design decisions may be determined or inappropriately influenced by team members other than the designer. This is more likely to occur when a non-designer is the lead on the design-build team.

f. The designer may be selected on the basis of price rather than qualifications, potentially compromising the public health, safety, and welfare. 
8. Are there other disadvantages of the Design-Build method for highway projects, in comparison to the Design-Bid-Build method that are not mentioned in Question $7 ?$

9. Answer the following Questions only if you participated in any Design-Build highway projects, not necessarily in Indiana.

a. Did the Design-Build method encourage innovation? If yes what innovation was proposed?

b. How far should the design for a particular project be developed, before it is given out for bidding?

\section{Please address any other items that you feel are relevant to the issue of Design-Build versus Design-Bid-Build.}

11. Would you be interested to be participating in a follow-up personal interview? 


\section{Appendix C-2 Design-Build Questionnaire for Members of ACEC}

Please return this questionnaire in one of the following ways:
1. E-mail
2. Regular Mail
3. Fax. No: (765) 496-1105
tymvios@purdue.edu
Nicholas Tymvios
School of Civil Engineering
1284 Civil Engineering Building
Purdue University
W. Lafayette IN 47906

\section{Name:}

Title:

Phone No.:

E-mail:

\section{Company name:}

Line of Business:

(Type of business your company is primarily working on)

1. Are you aware of INDOT's Design-Build program?

(Yes/No)

2. Did you ever consider participating in any Design-Build highway project? (Not necessarily with INDOT)

(Yes/No)

3. Did you ever participate in an INDOT Design-Build project?

(Yes/No)

4. Do you think that you will be interested in participating in any INDOT DesignBuild project in the future?

(Yes/No). If 'Yes' what types of projects will you be interested in participating in? If 'No', why not? 
5. Below are six of the advantages that have been observed about the Design-Build method of procurement for highway projects. Rate these from "Strongly Agree" to "Strongly Disagree".

a. Reduced Duration of Construction - Design-Build decreases the overall project completion time as compared to Design-Bid-Build since design and construction periods overlap, and redesign is mostly eliminated.

b. Contractibility/Innovation - Design-Build introduces construction knowledge into design early in the process.

c. Reduce Cost - Design-Build decreases the overall project cost as compared to Design-Bid-Build. Project costs are identified far earlier, allowing for budgetary concerns to be addressed early. Also value engineering and constructability are utilized since designer and contractor work as a team.

d. Single Point Responsibility - The Design-Build team has full responsibility for the outcome of the project. The contractor and the designer are allied and work together as a team, giving the owner the opportunity to focus on the scope and needs definition rather than coordinating the design aspect of the job with the construction aspect.

e. Continuity between Designer and Constructor - In DesignBuild projects, the same entity has the expertise to design the project and construct it.

f. In Design-Build projects, there is less misunderstanding between the parties involved.

6. Are there other advantages of the Design-Build method for highway projects, in comparison to the Design-Bid-Build method that are not mentioned in Question 5 ? 
7. Below are seven of the disadvantages that have been observed about the Design-Build method of procurement for highway projects. Rate these from "Strongly Agree" to "Strongly Disagree".

a. Loss of control over the design phase of the project - The subsequent design of a particular project is performed by the Design-Build team and the owner loses control of design.

b. It has been observed that some design - build firms build first and design later.

c. The owner has less input into the process and little control of the quality of the materials used in the project unless the owner has taken the time to complete a very detailed listing of materials to be used and identified other project controls that the Design-Build team is to meet.

d. The Design-Build project delivery system may be more labor intensive and technically demanding for the owner than is Design-Bid-Build. Design-Build projects require the owner itself to carefully prepare a scope of work that defines its requirements in detail.

e. The designer may be selected on the basis of price rather than qualifications, potentially compromising the public health, safety, and welfare.

f. The Design-Build project delivery system may discourage competition. Fewer entities have the inherent capacity to provide design-build services, which larger firms are able to provide

g. The magnitude of liability risk to the designer may discourage participation by highly qualified designers.

8. Are there other disadvantages of the Design-Build method for highway projects, in comparison to the Design-Bid-Build method that are not mentioned in Question $7 ?$ 
9. Answer the following questions only if you participated in a Design-Build highway project, not necessarily in Indiana.

a. Was the scope of the project clearly defined, and what could have been done to make it better?

b. Did you encounter any problems in the initial design process?

c. The Design-Build method is perceived to provide innovation in construction and design. What innovation(s) occurred, if any, in the Design-Build projects you participated in?

d. How far should the design for a particular project be developed, before it is given out for bidding?

\section{Please address any other items that you feel are relevant to the issue of Design-Build versus Design-Bid-Build.}

11. Would you be interested to be participating in a follow-up personal interview? (Yes/No) 


\section{Appendix D - ICI Comments}

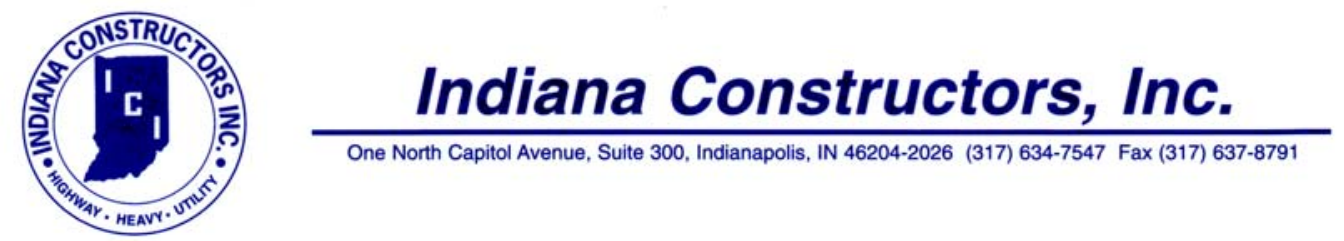

August 20, 2002

Mr. Barry K. Partridge

Chief

Research Division

Indiana Department of Transportation

1205 Montgomery Road

West Lafayette, Indiana 47906

RE: $\quad$ SP\&R Part II Research Study SPR-2497 “An Evaluation of Design-Build Projects in Indiana"

Dear Barry:

This is in response to your July 22 memo, which sought feedback on the draft final report of the Design-Build study. In the memo, you specifically asked that the following questions be addressed:

1. Does the report fulfill the study objectives defined in the study proposal?

2. Is the report written for the understanding of the intended user?

3. Does the report support the findings and conclusions offered and do you agree with them? Please explain.

4. Do you agree with the implementation suggestions? Please explain.

5. Does the Technical Summary contain the following three required elements: a short introduction of the study's background; a concise summary of the research results; and the highlights of proposed implementation?

6. Is the Technical Summary well-written and easy to read for dissemination purposes?

7. Which Division(s)/District(s) and who should be involved in the implementation of the research results?

8. Will you be participating in the implementation?

9. Do you recommend having a SAC meeting after revising this draft report to discuss the final version of the report and/or the implementation plan?

The following comments respond to these questions on behalf of Indiana Constructors and represent the views of the construction industry participants on the Study Advisory Committee. 

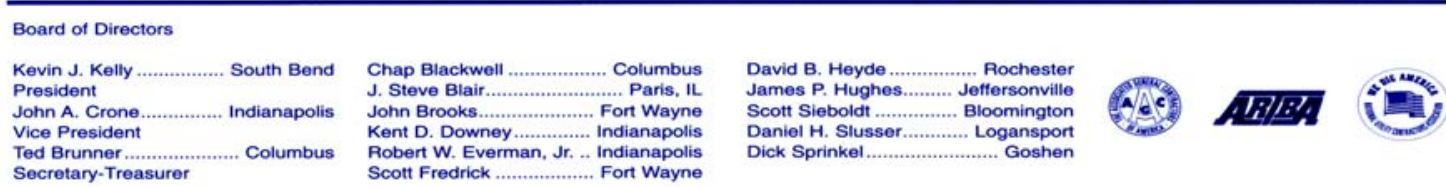

While the Draft Final Report (July 2002) for the Design-Build study shows progress compared to the draft issued in September 2001, it still falls short of the objectives, which were to assess all possible impacts and generate information that can be used by INDOT in making decisions on how to best use this project delivery process. Many of the conclusions stated in the report are also not supported by the research that was performed.

The July 2002 version does a much better job in acknowledging both INDOT and industry concerns about the INDOT Design-Build process. Unfortunately, these concerns are largely ignored in the conclusions of the report.

\section{Case Study Comparison Between Design-Build and Design-Bid-Build}

Examining first whether the report assesses all possible impacts, some relevant comparisons are absent and others are not examined in the appropriate context. Among the concerns with the earlier draft was the fact that there was little direct comparison between Design-Build contracts and the conventional Design-Bid-Build contracts. The latest draft has attempted to address that shortcoming by adding a brief section on case studies. However, the number of projects compared is insufficient to draw any meaningful comparison. Aside from the limited number of projects compared, the factors considered may not have been the best choices to provide an in-depth comparison of these two methods. For example, the report emphasizes the comparison in design time and total construction time. However, the design time between these two methods is not an apples/apples comparison. The design time shown for Design-Build projects is the time needed to develop a detailed scope or a design that is only $20-30 \%$ complete, while the time for the Design-Bid-Build projects is the time that it took to develop plans that are $100 \%$ complete. Our industry has questioned why the normal design process takes so long and INDOT has shown on a few expedited design projects that $100 \%$ complete plans can be generated in approximately the same time that it took to produce the detailed scopes for these Design-Build jobs. It also appears that, for most of these projects, the time counted as design time is all time from the beginning of design (which is not defined) to the letting date. In some cases, however, the design may have been completed for several months before the contract was let. Delays sometimes occur because of right-of-way or funding problems that have nothing to do with the design process. A more appropriate measure of design time would be to count all time from the beginning of design to the time that final drawings were submitted to INDOT.

As plans were developed, there may also have been significant differences in the amount of review by INDOT and the turnaround time for that review. This further complicates trying to attach significance to the time differences. This part of the analysis overlooks the fact that much of the design activity during a Design-Build contract occurs concurrently with construction. Because of this Design-Build feature, it is possible to deliver a project in less time compared to conventional Design-Bid-Build as it occurs in the normal INDOT time frame. It is likely that the total manhours spent on the actual design are comparable between the two methods. If you further consider that multiple 
teams are preparing design plans in a Design-Build scenario, more overall time (and design firm and contractor resources) are expended when the Design-Build method of project delivery is used.

The emphasis on total construction time seems misplaced. A more important criterion is the number of days that traffic is restricted. This is not reflected in the data collected on these projects. A more detailed analysis could also have compared number of change orders, DBE participation, failed materials, quality of materials based on acceptance test results, and probably several other relevant factors. Last December, we suggested that the Study Advisory Committee (SAC) be consulted regarding the specific factors that should be evaluated.

In addition to not examining the most appropriate criteria for construction time, Table 3 on page 81 distorts the impact of $\mathrm{A}+\mathrm{B}$ bidding on reducing the impact of construction on highway users. The table makes it appear that $A+B$ is ineffective since it shows this particular project as having the construction time with the longest duration. However, the $\mathrm{B}$ portion in an $\mathrm{A}+\mathrm{B}$ bid normally pertains only to days that traffic is restricted not to the total construction time. INDOT's experience has found $\mathrm{A}+\mathrm{B}$ to have a very positive impact on reducing motorists' inconvenience. This bidding approach should be considered for all high-profile jobs regardless of which project delivery method is used. Since there is no explanation offered for noting that the one contract used $\mathrm{A}+\mathrm{B}$ bidding, either all mention of $\mathrm{A}+\mathrm{B}$ should be deleted from the Case Studies and Conclusions portions of the report or some justification provided for that reference.

Because the Case Study information does not provide a meaningful comparison between the two project delivery methods and can be misinterpreted to imply that Design-Build reduces construction time, we suggest that the Case Study material be deleted from the report.

\section{Information To Guide INDOT}

The second objective was to generate information to guide INDOT on its future use of Design-Build. The report does contain some information that will be helpful to INDOT in this regard. However, recent information does make us question the accuracy of one statement. The report (page 2) notes that Design-Build is one of the "main methods of procurement" in Ohio. In an article last month, the Cleveland Plain Dealer cited the ODOT director as stating that only a small portion of the ODOT budget will be used for Design-Build projects. Furthermore, the report does not provide detailed enough guidance to help the Department address some of the more critical issues that have been raised about Design-Build.

\section{$\underline{\text { Conclusions }}$}

The conclusions section acknowledges many of the problems with the INDOT DesignBuild process but appears to question the validity of these problems by attributing them to resistance to change. Instead, the draft report refers to the "proven benefits" of Design-Build. However, under the research that has been presented, the benefits are no more proven than the problems. The proven problems that are listed must be addressed in order for INDOT to have a successful Design-Build process. 
One of the most critical of those problems is the wide discrepancy between bid prices and the engineer's estimate. The report, however, provides no guidance on how INDOT can address this problem. INDOT must improve the accuracy and credibility of its estimates on Design-Build contracts. The report should offer INDOT guidance on how this can be accomplished.

We also challenge two of the four "benefits" that are cited. While Design-Build projects are brought on-line faster than conventional projects, the Expedited Design-Bid-Build process provides comparable results that are overlooked by the study. Also, the idea of reduced supervisory needs seems to be in direct conflict with the report's own conclusion \#6, which discusses personnel needs and the problems for INDOT supervisory personnel.

While each of the seven conclusions has some merit, they should be enhanced to further help INDOT chart its future course on Design-Build. Some thoughts that may help enhance these points follow:

- Conclusion \#1: We agree with the point made that “...larger projects have excluded many... contractors due to the financial risks that are involved with large projects." This is the industry's major concern with all project delivery processes used by INDOT. Smaller, reasonably sized projects would increase the number of bids received on each.

Some small projects may still involve complex designs that would not encourage participation by smaller contractors and design firms. Using "smaller projects with minimal design" would better describe the type of projects that have been mentioned in some discussions.

- Conclusion \#2: First, Design-Build is not a fast-paced method of construction. Rather it may be a faster-paced delivery process only because the design process occurs somewhat simultaneously to construction. The actual construction time, itself, is similar to other methods of delivery including conventional Design-BidBuild.

Second, Design-Build projects are no different than any major construction project in that a late fall letting allows the contractor to hit the ground running when favorable weather arrives in the spring. It is not clear how this helps subcontractors involved early in the project since the primary problem noted was that they have difficulty submitting a bid when they are working from less than complete plans. The timing of the letting will not address this situation.

Third, while we don't disagree with the idea of limiting Design-Build only for projects that are free of utility problems, usually utility conflicts are not discovered until the construction phase of the project. INDOT should consider the appropriateness of requiring Subsurface Utility Engineering (SUE) in the design phase of every construction project, regardless of the project delivery method being used. The U.S. Department of Transportation Federal Highway Administration defines SUE as an engineering process for accurately identifying the quality of subsurface utility information needed for highway plans, and for acquiring and managing that level of information during the development of a highway project. 
- Conclusion \#3: Rather than stating the percent of plan development used as bid documents in other states, INDOT might be better served by knowing what factors are important in the detailed scope and what factors are not needed and how this might vary depending on the nature of the project. It also seems unnecessary to utilize Design-Build in a situation where the plans have been developed to an $80 \%-90 \%$ completion.

- Conclusion \#4: Certainly INDOT needs to evaluate the technical proposal requirements. The study should provide guidance on what elements are important to knowing whether the design complies with the scope. The level of innovation allowed in the bidding process also needs to be clarified so that all bidders have the same opportunities. Based on the feedback we get from industry, this is one of the critical problems with INDOT's Design-Build process. Yet, the study does not cite this as a problem. On the one hand, the report noted a comment from a contractor that Design-Build innovations "saved the state of Indiana \$4 million on bid day" (p. 86). On the other hand, some contractors claim that innovation "is non-existent with the current policy employed by INDOT" (p. 75). The bid documents need to be crystal clear as to the extent to which variations from the Department's standards, specifications, and design manual are permitted. The policy stated in the bid documents then needs to be adhered to during construction. The report should give INDOT guidance on what that policy should be. The amount of the stipend should be dependent on the amount of design required for a specific project. The report should provide INDOT with some guidance on the appropriate stipend levels for different types of projects. Fair stipends will encourage more bidders.

- Conclusion \#5: The report should go a step further and elaborate on the scope of improvements that are needed.

- Conclusion \#6: This conclusion is not only relevant to the Design-Build delivery process, but to all project delivery processes that include an accelerated construction schedule.

- Conclusion \#7: We think industry has a better understanding of the process than the report gives them credit for. We think industry understands the process and, based on that understanding, believe that Design-Build is neither in industry's best interest nor in the Department's best interest for most projects. If better understanding is a key, as the report states, then the report should provide an outline of what specific material should be covered at an information session. We believe part of the problem is the lack of clarity regarding the risks assumed by a contractor in Design-Build. Clarifying that risk, and limiting a contractor's exposure to those items a contractor can control, would help encourage contractors to consider bidding future Design-Build contracts. The training of INDOT personnel is important. They need to have a clear understanding of how their role on a Design-Build project differs from their role on conventional projects.

The report also needs to recommend that INDOT continue to evaluate the Design-Build process, particularly as it addresses the concerns that have been raised. Continuing, but more in-depth, case studies will be helpful. We think you will find considerable 
disagreement to the report's conclusion that "Design-Build has so far proven to be effective for INDOT." Our perspective is that the process has shown that, if INDOT can adequately address the key issues noted in this response, Design-Build can be an optional method (as opposed to the preferred method) when the right conditions exist. Further thought needs to be given to defining the right conditions. Certainly, right-of-way issues, utility complications, environmental issues, and probably some other factors need to be considered in addition to the factors listed in the final paragraph of the report.

While we appreciate the opportunity the researchers provided to raise these concerns at a recent meeting and hope that the final version will reflect the comments made at that meeting, we ask that our response - and any comments submitted by other SAC members - be included as another Appendix to the report if the Final Report does not address the concerns discussed at this month's SAC meeting. This way, these concerns will be available to any person reviewing the report.

Assuming that the report's intended users are the INDOT Executive Staff, the report is written for their understanding. The Technical Summary addresses the required elements. The Technical Summary should acknowledge in its Findings that there are a number of problems with the INDOT process. This would include the issues listed in the first two paragraphs on page 83. Other than the absence of this critically important information, the Technical Summary is well written.

Industry is certainly willing to continue its active role in the Design-Build process through working with the Department to address the concerns that have been raised and in continued evaluation of Design-Build. We also think that District Construction personnel need to be involved in this process.

The value of an additional SAC meeting depends on the willingness of the researchers to consider significant changes to the report. If there is a willingness to talk through these concerns and, if necessary, do further research, then a meeting could be valuable. Otherwise, we suggest just including our comments in the report.

Lastly, we do ask that the graphs showing responses from ICI members be clarified to note that these reflect only the views of those members who responded to the survey. As written, it appears that these are the views of the entire membership. Also, please make sure there are no places where the report appears to indicate that certain views are ICI's. The surveys returned represent only the views of those member companies and not the association.

Respectfully submitted on behalf of Indiana Constructors, Inc.,

Charles V. Kahl

Executive Director 